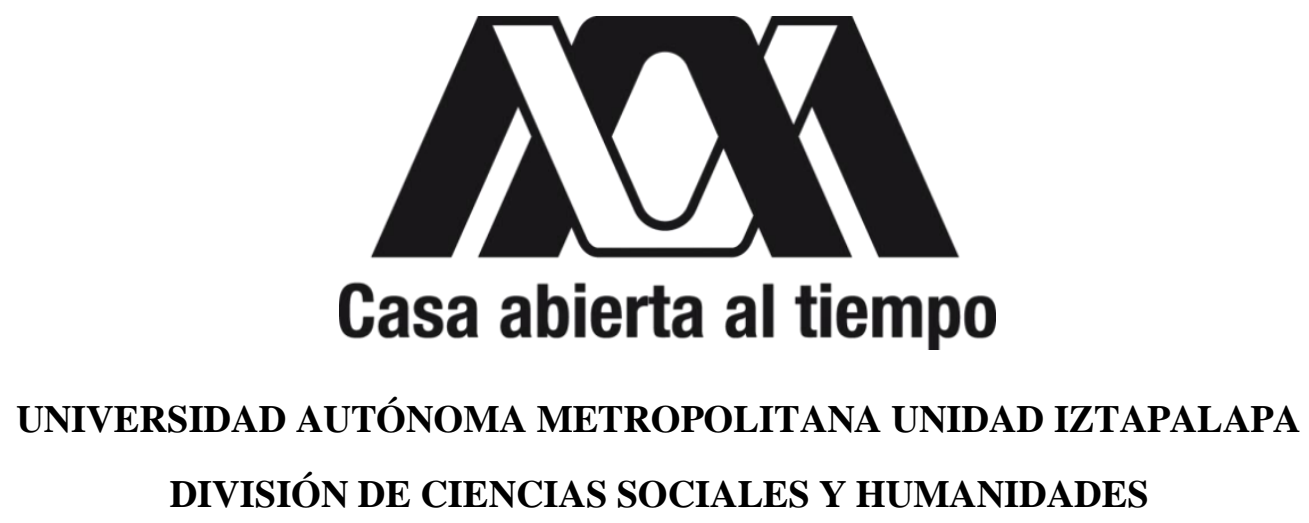

“CONSTRUCCIÓN SOCIAL DEL NOVIAZGO EN FACEBOOK”

IDÓNEA COMUNICACIÓN DE RESULTADOS

PRESENTA:

VERÓNICA JANETTE CASTILLO BRAVO

2173800758

PARA OPTAR POR EL GRADO DE

MAESTRA EN PSICOLOGÍA SOCIAL

DIRECTOR(A): Dr. Josué Rafael Tinoco Amador

SINODAL: Dr. José Alfredo Nateras Domínguez

SINODAL: Dra. Adriana Gil-Juárez

IZTAPALAPA, CIUDAD DE MÉXICO, 03 DE DICIEMBRE DE 2019 


\section{INDICE}

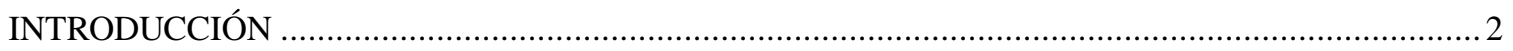

¿Por qué estudiar las relaciones de pareja que se establecen en Facebook? ........................................... 2

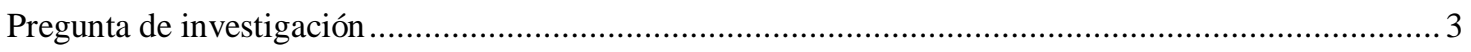

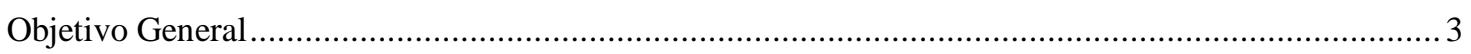

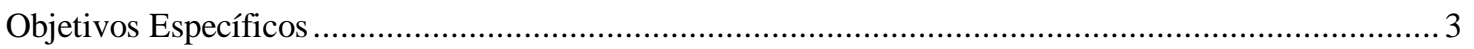

CAPÍTULO 1. LA RELACIÓN DE PAREJA A TRÁVES DE LA HISTORIA …...................................... 4

1.1.- Relación de pareja: libre elección, amor romántico y sexualidad.................................................... 4

1.2.- La pareja en nuestros tiempos: amor, atracción, cortejo e intimidad ............................................ 9

CAPÍTULO 2. REDES SOCIALES CIBERNÉTICAS: UN ESPACIO PARA ESTABLECER

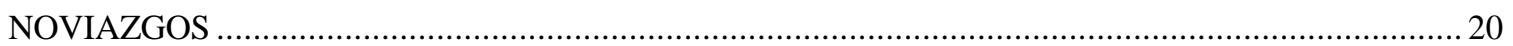

2.1. El uso cotidiano de la computadora y el teléfono móvil .............................................................. 20

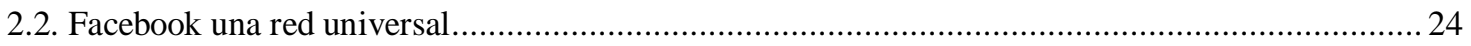

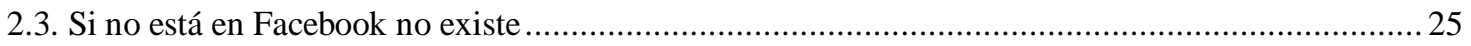

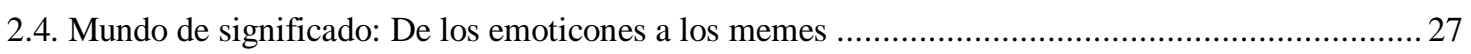

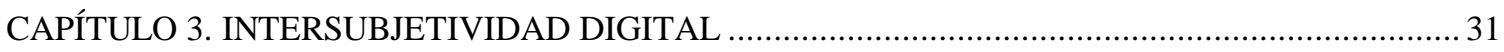

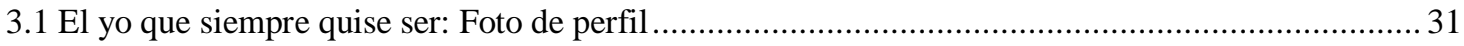

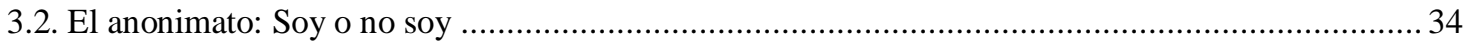

3.3. Una mirada multidisciplinar: Relaciones de pareja a través de Facebook..................................... 37

CAPÍTULO 4. EL PENSAMIENTO SOCIAL SOBRE EL USO DE FACEBOOK COMO MEDIO PARA

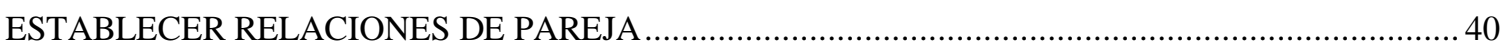

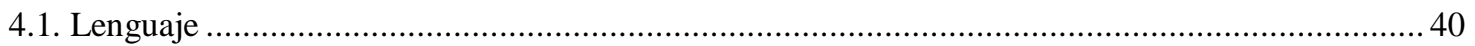

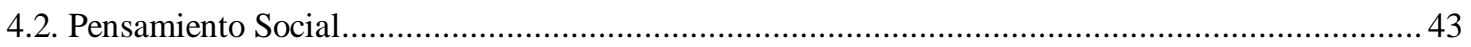

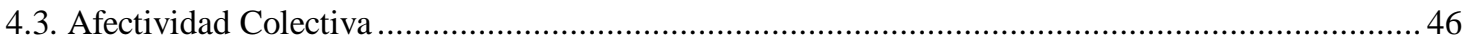

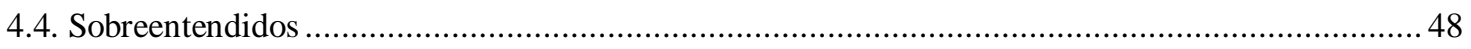

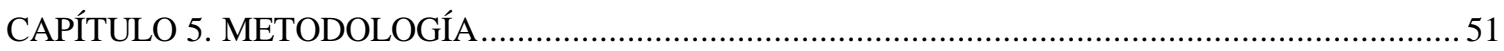

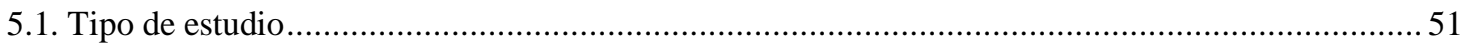

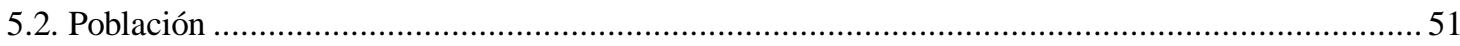

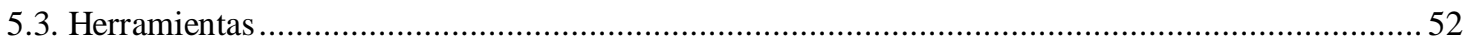

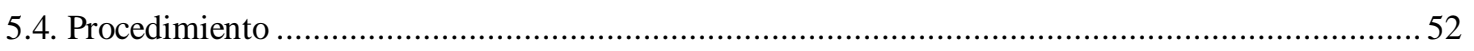

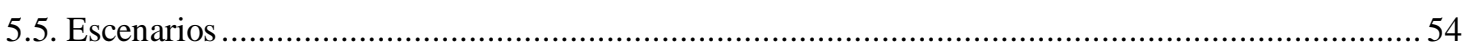

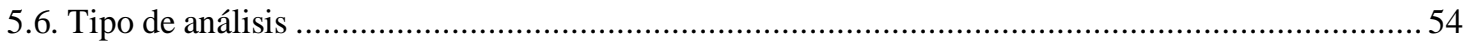

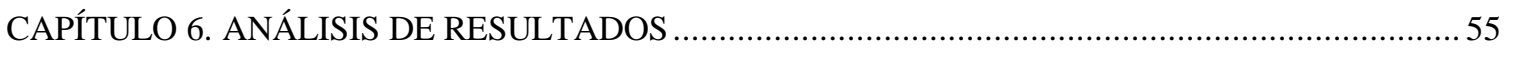

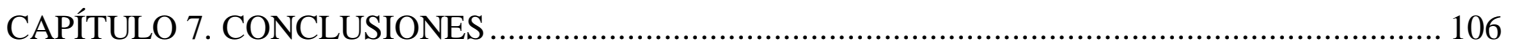

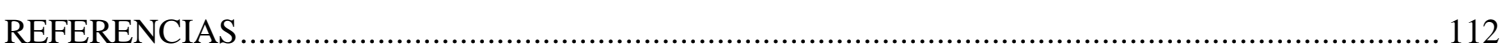

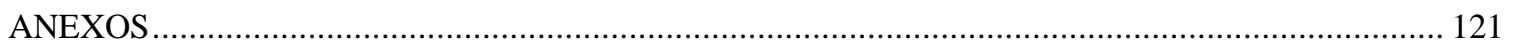




\section{INTRODUCCIÓN}

¿Por qué estudiar las relaciones de pareja que se establecen en Facebook?

Las relaciones de pareja son parte de nuestra vida cotidiana, así que alguna vez las hemos experimentado, en ellas se presentan prácticas sociales y procesos que la consolidan, como el cortejo, la conquista, la declaración amorosa, hasta definirse como una pareja; dentro de este proceso se encuentran los detalles, la muestra de afectos, las citas, las conversaciones constantes, etc.; pero ¿qué pasa cuando se inician y se mantienen a través de los medios tecnológicos, donde el contacto físico está ausente (por un tiempo) y las conversaciones se manifiestan por medio del lenguaje escrito, de material visual como las imágenes y las fotografías, así como la construcción de una dinámica social dentro de Facebook? Estamos ante un cambio en las prácticas sociales, es decir, la forma de interactuar con los otros se apoya de otras herramientas, pero que aún se conservan elementos como la corporalidad y las afectividades para construir interacciones sociales.

Puede considerarse un tema contemporáneo y de "moda", pero aquí lo importante es identificar un replanteamiento en la manera en que establecemos relaciones afectivas y la resignificación que conlleva la noción de iniciar una relación de pareja a través de Facebook pues cuando se ausenta la presencia física, se vuelven diversas la imaginación, la representación del "yo" y la relación entre la vida offline y online. Por lo tanto, es necesario poner atención en los usuarios e identificar esas construcciones sociales.

Por otro lado, se encuentra el uso del lenguaje visual para relacionarse, comprenderse y crear significados sociales pues posiblemente ayudan a que estos lazos amorosos tomen sentido, por ejemplo, el compartir información acompañada de imágenes, los memes, la transformación de las palabras escritas, el uso de los emoticones y lo que significa dar un me gusta, me encanta, me entristece, me enoja y me divierte, comprender el "visto", el acto de bloquear, eliminar y enviar mensajes constantemente.

Respecto a estos temas deberíamos dejar ya el discurso sobre la incorporación de estos medios a nuestra vida afectiva, y deberíamos enfocarnos sobre el proceso, el uso y la transformación de la manera de interactuar y relacionarnos con los otros dentro de la red. Así 
también, la utilización de una metodología cualitativa que nos ayuda a estudiar este tipo de eventos sociales, como la entrevista estructurada, que permitirá entender y comprender (a partir de determinadas preguntas) la construcción del mundo de significado del noviazgo que se establece en Facebook, y así ser un parteaguas en el abordaje de las nuevas necesidades de la investigación social.

Este estudio se enfocará en el noviazgo, entendido como una relación afectiva en la cual su concepción se ha transformado con el paso de los siglos pasando de una relación para preservar el linaje hasta buscar la felicidad y la autorealización (cómo veremos en el siguiente capítulo); y por otro parte, se investigará Facebook por ser una de las redes sociales más populares y cuyo objetivo inicial no fue crear lazos afectivos.

Pregunta de investigación

- ¿Cómo se inician, se mantienen y finalizan las relaciones de pareja a través de Facebook?

\section{Objetivo General}

- Comprender el inicio, el mantenimiento y el final de las relaciones de pareja a través de Facebook.

\section{Objetivos Específicos}

- Comprender el proceso de las relaciones de pareja que se inician a través de Facebook.

- Identificar la afectividad colectiva en las relaciones de pareja que inician a través de Facebook.

- Comprender los sobreentendidos que se generan en el uso de Facebook para iniciar, mantener y finalizar la relación de noviazgo.

- Identificar el papel que juega el lenguaje visual (texto e imágenes) en la construcción de la relación de pareja en Facebook.

- Identificar si existe diferencia de género en la construcción de la relación de pareja a través de Facebook. 


\section{CAPÍTULO 1. LA RELACIÓN DE PAREJA A TRÁVES DE LA HISTORIA}

1.1.- Relación de pareja: libre elección, amor romántico y sexualidad

Antes de comenzar a relatar un poco acerca de algunas de las transformaciones por las cuales han pasado las relaciones de pareja, me gustaría resaltar que para esta investigación la relación afectiva, el noviazgo y la relación de pareja serán sinónimos, pues este tipo de relación ha pasado por varios cambios en su concepción, dejando un rastro que seguir para entender cómo se ha modificado la forma en la que pensamos estos lazos afectivos.

Un vistazo en el pasado: ¿cómo eran las relaciones de pareja?

\section{En la antigua Grecia}

En esta época ya se tiene registro de las relaciones de pareja entre hombres y mujeres, donde la mujer toma diferentes roles dependiendo de la dinámica social, pues podía ser concubina o esposa (Bologne, 2017). Las esposas se enfocaban en tener descendencia legítima, mientras que las concubinas satisfacían los placeres de los hombres, es decir, ellos tenían una vida sexual más activa y ellas tenían que limitarse a tomar un determinado rol, de lo contrario eran juzgadas por las normas morales sancionándolas socialmente (Corzo y Arteaga, 2018).

\section{En la Antigua Roma}

De acuerdo con Corzo y Arteaga (2018), en este periodo la situación era parecida, los matrimonios eran arreglados a partir del linaje, forjando las alianzas políticas o sociales entre familias, y respecto al plano sentimental también se distinguía el rol de esposa por un lado, y las bajas pasiones por el otro.

\section{En la Edad Media}

Para principios de la Edad media, no había gran cambio respecto su establecimiento pues todavía eran arregladas a través de las clases sociales y el linaje; pero años después, la Iglesia Católica comienza a imponerse en la vida en pareja, postulando que el casamiento es para toda la vida y solo la muerte los separaría, en otras palabras, se impuso la fidelidad entre los esposos; además se criminalizó el placer, considerándolo como pecado, así entonces, la 
sexualidad solo es empleada para la concepción de los hijos; mientras la idea del amor solo era concebida como "amor a Dios", un sentimiento puro, casto, caritativo que nacía después del matrimonio (Corzo y Arteaga, 2018).

Fueron varias las restricciones en la relación de pareja que la sensación de amar no tenía que ver con el matrimonio, pues era arreglado sin consentimiento de los involucrados y las normas sociales impedían o dificultaban la separación. Posteriormente, para los Siglos XVIII, XIX y XX también se presentaron transformaciones en el pensamiento que modificaron el establecimiento y concepción de estas relaciones, a continuación haré una breve explicación sobre esto:

\section{Modelo Institucional (1700-1850)}

Para Finkel, et al. (2014), las relaciones de pareja se han modificado con el paso de los siglos, debido a la estructura social y cultural, para estos autores existen tres modelos que explican estas transformaciones; de acuerdo con su línea del tiempo, para los años 1700 y 1850 se destacaba el modelo institucional, donde lo más importante era satisfacer las necesidades básicas (comida, crianza y protección) apoyando el interés en común de la sociedad (armonía económica y social), pues las familias estaban interconectadas, un ejemplo de esta organización eran las familias campesinas (matrimonios o uniones estables aceptadas por los padres).

Modelo Acompañante y su romanticismo (1850-1965)

Con el paso de los años, comenzó a disminuir la influencia de los padres permitiendo la libre elección de pareja, así da paso al siguiente modelo, el modelo acompañante y su romanticismo que abarca los años 1850 a 1965; la estructura social cambia, comienza la transición del ámbito rural al urbano, modificando la dinámica del trabajo, sobre todo para las mujeres ya que su contribución en la economía se hizo menos central, pues alguien debía cumplir con las tareas domésticas, y como ellas estaban asociadas con la maternidad, comenzaron a ayudar más en el hogar y en la crianza de los hijos, así pues está nueva organización modificó los pensamientos sociales de aquella época, pasando de un código de obligaciones con la sociedad, a entender que la relación de pareja debe basarse en los lazos 
afectivos y compañerismo entre las dos partes, pues como las mujeres ya no apoyaban fuertemente en el ingreso económico, elegir una pareja se fue más por el lado sentimental.

De acuerdo con Finkel et al. (2014) este modelo abarca dos periodos, primero el matrimonio romántico que surge entre los años 1850 y 1900, ya que a mediados del siglo XIX se origina la idea del amor romántico como un sentimiento gentil y casto, interpretándose como sentimientos de compañerismo y afecto que se cultivan después del matrimonio; se presenta el enamoramiento durante el cortejo y casarse toma como objetivo prolongar esa emoción, en contraste con el modelo anterior donde el amor conyugal se daba después de casarse y/o vivir juntos (Finkel, et al., 2014).

Para 1900 y 1965 se presenta el matrimonio de compañeros, teniendo como elementos la expectativa del amor romántico, la intimidad profunda (relacionada con el deseo carnal), la excitación y la realización sexual, esto se debe a la relajación en las restricciones sociales, pues el cortejo comenzó a ser mejor visto y como parte de la exploración sexual, así las mujeres y los hombres podían interactuar en diferentes espacios sociales (restaurantes, bailes, teatros), generando la oportunidad de vivir la sexualidad (o intimidad física) antes del matrimonio, es decir, abre el panorama a tener más experiencias sexuales antes de formalizar la relación.

\section{Modelo Autoexpresivo (1965- al presente)}

Por último, está el modelo autoexpresivo: el contracultural que abarca de 1965 al presente, en el cual se muestra al matrimonio como medio para obtener la autoexpresión y perseguir la libre elección, ¿a qué se refiere con esto? Bueno, ahora las relaciones de pareja se enfocan en el individualismo, pues enfatizan en la autorealización, autosuficiencia y autodeterminación, es decir, se busca un crecimiento personal; esto deriva de la revolución contracultural del año 1950 con el empoderamiento de las mujeres y las minorías desfavorecidas en la estructura social; y por otro lado, se debe a la revolución sexual en la década de 1960 modificando así la concepción de la relación de pareja, separándose poco a poco del único objetivo de procreación (Finkel, et al., 2014), ¿cómo se dio esto? En consecuencia de la invención de los métodos anticonceptivos, la sexualidad fue tomando otro rumbo, que da cabida al placer y al deseo, pues recordemos que está marcada por restricciones morales por parte de la iglesia católica u de otra religión. 
De acuerdo con Foucault (citado en Rodríguez, 2001) la sexualidad es un conjunto de significados que tienen raíces en el pasado cristiano y precristiano, por lo tanto, cuestionarla y cambiar sus objetivos tuvieron un gran impacto en la forma de considerar la vida en pareja.

Para 1970 el papel de la intimidad, la comprensión emocional, la empatía y la satisfacción sexual fueron consideradas piezas clave en la relación de pareja (Esteinou, 2009). Entonces, estas revoluciones impulsaron a los hombres y a las mujeres a reflexionar y resignificar las obligaciones tradicionales (Finkel, et al. 2014).

Así pues, de acuerdo con Finkel, et al. (2014), en nuestro presente la relación de pareja pasó de una institución formal que satisfacía las necesidades de la sociedad, a una relación de compañerismo fundamentada por el amor, la cual ayuda a cumplir objetivos de sentirse amado, satisfecho, feliz y autorealizado ¿cómo es esto? Después de varias transformaciones, la relación afectiva (como la conocemos ahora) se fomenta con el surgimiento y mantenimiento del sentimiento llamado "amor" entre dos personas (seres complejos y emocionantes) a través de la exploración mutua; se manifiesta la compañía y se experimentan momentos juntos para construir una intimidad, es decir, conocerse mutuamente. Entonces, para identificar estas formas de vivir una relación de pareja es necesario entender las condiciones sociales, históricas, políticas, económicas y culturales.

\section{Roles de género: la pareja, el amor romántico y la sexualidad}

La asignación de roles, la concepción del amor y de la sexualidad constituyen el desarrollo de la vida en pareja que se va modificando acorde a los diferentes pensamientos y prácticas sociales de cada contexto socio-histórico (Giddens, 1995; Barrios y Pinto, 2008).

Bajo a esta mirada, Fernández (2000), señala que la construcción de un sentimiento como el amor, se debe a nuestras interacciones sociales, al lenguaje, a las conversaciones cotidianas y a los medios de comunicación; por ejemplo, en las películas identificamos roles sociales, es decir, cómo debe ser una mujer y un hombre cuando están enamorados y qué se espera de ellos en una relación afectiva, en la época de oro del cine mexicano de los años 30 's a los 50's, los hombres portaban trajes de charro, montados en sus caballos y dispuestos a robarse a la mujer que les gustara, o también estaban destinados a casarse debido a los acuerdos entre familias de un mismo estatus social (no había libre elección), por otro lado, la 
mujer era callada, sumisa, abnegada y dispuesta a complacer a sus padres de las decisiones que tomen por ella, así pues había una evidente línea que diferenciaba el ser masculino y el ser femenino en las relaciones amorosas.

Entonces, las películas, las series de televisión, las telenovelas y los realities que se encuentran en los medios de comunicación como la televisión o internet nos dan un panorama de cómo se concibe los roles de género y nuestros pensamientos como sociedad (Estébanez, 2015). En las conversaciones cotidianas también se observan las formas de ligue, del coqueteo y qué tiene que hacer una mujer para llamar la atención de un hombre y viceversa, conocer esta sociabilidad $^{1}$ nos ayuda a comprender qué es el amor en una cultura como la nuestra.

Como se mencionó anteriormente, la idea del amor romántico (como una emoción que se piensa y se actúa conforme a las normas culturales) se ha construido en el transcurso de los años, originándose en el siglo XIX, y teniendo como esencia la definición de los roles de género debido a toda la dinámica laboral causada por la urbanización, la división de labores y las normas de la iglesia católica, así entonces, la mujer debía ser dulce y confinada al hogar, en cambio, el hombre era quien mandaba (Esteinou, 2009; Esteinou, 2017; Finkel, et al., 2014).

Como resultado de la revolución sexual, para Giddens (citado en Esteinou, 2017), la concepción del amor y la construcción de las relaciones afectivas ya no estaban cimentados por la procreación, por lo que, se genera un amor confluente donde existe la "igualdad" en el dar y recibir, enfatizando en la satisfacción emocional.

Sin embargo, sobre el tema de la sexualidad para Bertran (citada en Torres, 2018), en nuestra actualidad, la sexualidad femenina está sometida por la masculina, el hombre puede tener una gran diversidad de experiencias sexuales antes de formalizar o de contraer matrimonio, en cambio, las mujeres deben limitar este tipo de relaciones.

Nos encontramos ante reglas morales que siguen controlando la sexualidad, y por ende influyen en la interacción y manteamiento del noviazgo. Así entonces, varios autores

\footnotetext{
${ }^{1}$ Para Simmel, sociabilidad es un mundo convencional de contactos, acercamientos, adornos, gestos que construyen la estructura social, es un arte de ser y de hacer.
} 
(Barrios y Pinto, 2008; Blanco, 2014; Esteinou, 2017; Estébanez, 2015; Rodríguez, 2012) coinciden que la relación de pareja es desigual, elegida y mantenida a través del amor romántico.

Cabe señalar que para esta investigación no me enfocaré en esta desigualdad de género, aunque no se niega su existencia, solo contemplaré si se presenta alguna diferencia entre hombres y mujeres en cuanto al uso de Facebook para establecer relaciones de pareja.

Como vemos la concepción del amor construye un "deber ser", las pautas de acción para cada género, así como las prácticas y costumbres que sustentan los vínculos amorosos, por ejemplo, la masculinidad está asociada con la incontrolabilidad sexual, y la feminidad está asociada a la pasividad y el sentimentalismo, en donde "la mujer de la mano de un hombre podrá estar completa" es decir, hay reglas que seguir, impuestas por la sociedad y reproducidas en la sociabilidad (Estébanez, 2015).

\section{Relaciones heterosexuales: Una hegemonía}

Por otra parte, para Foucault (citado en Rodríguez, 2012), las ideas del amor contribuyen a la normalización y naturalización de la heterosexualidad; Bologne (2017), señala que no se sabe con claridad el momento del surgimiento de las parejas heterosexuales, pero existen registros donde se menciona lo relevante que fueron las uniones de amistad y de fraternidad del mismo sexo, pero que después fueron satanizadas por diferentes grupos religiosos, creando así una norma hegemónica, es decir, desde ese tiempo y hasta ahora se penalizan ciertos tipos de relaciones afectivas creando una presión social respecto a cómo deben ser nuestras relaciones sociales, defendiendo la idea de procreación como motivo principal de la relación entre dos personas de diferente género. Sin embargo, esto se ha ido modificando debido a la lucha de diversos grupos minoritarios que ha generado la aceptación paulatina de estas relaciones afectivas entre mismos sexos, incluso abriendo la posibilidad de considerarlos como matrimonios legales (Bologne, 2017).

1.2.- La pareja en nuestros tiempos: amor, atracción, cortejo e intimidad

A partir de las diferentes transformaciones sobre la sexualidad, el amor, la libre elección y la pareja (conocer al otro de manera íntima), comenzó el surgimiento de diversos tipos de relaciones interpersonales, por ejemplo, como se señaló en el apartado anterior, en 
el noviazgo se establece y se encuentra el rol de novios, un tipo de relación formal, donde comúnmente es regulada por la monogamia y la exclusividad de solo dos participantes, con la finalidad de construir una familia y un matrimonio, que esto son reglas a seguir a partir de la religión y de su historia como pareja heterosexual.

Por otro lado, se presentan relaciones en las cuales no hay un "para siempre" (Esteinou, 2017), como los amigos con derechos, los free, etc. donde las relaciones sexuales por lo regular son predominantes (Tenorio, 2010).

Para varios autores (Rodríguez-Brioso, 2004; Finkel, et al., 2014; Rodríguez, 2012), en nuestra actualidad, vivimos y experimentamos relaciones establecidas lejos del motivo de procreación, a esto se le denomina sexualidad plástica (Giddens, 1995), por lo tanto, si ahora se está más lejos del único propósito de procrear hijos, ¿para qué se tiene una pareja? En las sociedades modernas los noviazgos tienen como objetivo la felicidad, sentirse bien y compartir momentos con la otra persona, por supuesto, acompañados de pautas tradicionales, como el ejercicio de la monogamia, tener como fin el matrimonio, el ideal de una relación romántica, encontrar el amor verdadero y el amor como base del sexo (Rodríguez-Brioso, 2004); pero, ¿Cómo se construye este tipo de relación?

Por un lado, como ya se había señalado, el amor romántico es una emoción que nace y crece de acuerdo a ciertas exigencias sociales y económicas que consiste en la idealización del otro, donde se espera un mutuo sentimiento así como la presencia de la atracción sexual, pero que al mismo tiempo fomenta el papel de los roles de género en la sociedad (Rodríguez, 2013; Esteinou, 2017).

\section{Atracción interpersonal}

Por otra parte, la atracción interpersonal juega también un papel importante. De acuerdo con Puma (2012), la atracción es la inclinación hacia algo o alguien, lo cual implican dos aspectos, por un lado, un proceso de cortejo, donde el gesto comunicativo dentro de una interacción (Esteinou, 2017) va en el intuir y resaltar las cualidades de la otra persona, y por otra parte, se encuentra el atractivo físico ya que es considerado la carta de presentación ante los demás, que dependiendo de lo que se considera como "bonito" o "bello" podrá llamar nuestra atención, por ejemplo, características como la piel bronceada o clara, la delgadez o 
la robustez, los ojos grandes y la nariz pequeña pueden ser códigos de belleza dependiendo de cada contexto socio histórico. Siguiendo con la argumentación de Puma (2012), los hombres y las mujeres eligen a su pareja de manera diferente pues mientras que los primeros se basan más en las cualidades físicas, la intimidad y la personalidad; las segundas toman en cuenta las emociones, el humor y la personalidad; y ¿Cuáles son esas formas de coqueteo y ligue que dan pie al inicio a una relación de noviazgo? Bueno, para Simmel (citado en Gómez, 2006), en la coquetería se busca agradar o provocar deseo por medio del atractivo físico y acciones que insinúen un propósito (sexual o sentimental); para identificar esos propósitos se interpreta el seguimiento de la comunicación (a partir de enviar mensajes frecuentes o verse físicamente), ser cariñoso, esos elementos se interpretan y se genera una idea de que se está ante una posible relación de noviazgo o en una relación meramente sexual o fugaz (Ojeda y Avilés, 2018).

\section{Coquetería: Una Dinámica Social}

De acuerdo con Simmel (citado en Gómez, 2006), la coquetería es una característica relacionada con las mujeres donde se busca el agrado del otro desde la perspectiva espiritual hasta utilizar el atractivo físico donde simultáneamente se dice un sí o no; es un momento que no es duradero ni tampoco se expresa de manera directa; está ligada con el poseer o no poseer, esa dinámica de un equilibrio fluido que aparentemente no tiene fin. Para el autor existen tres tipos de coquetería: la aduladora donde existe la posibilidad de conquistar, pero la otra persona no se deja; la despreciativa: que también existe la posibilidad de ser conquistado pero la otra persona no es capaz de hacerlo y por último está la provocativa de que hay una posibilidad de ser conquistado y se desafía al otro que lo intente.

Se vuelve dinámica cuando se comienza a presentar un acuerdo entre ambas partes y se llega a un contrato social, pero sin dejar de lado que es la mujer quién decide, quién aprueba o no que la otra persona se acerque, marcando así una selección, insertando al varón a la incertidumbre (Gómez, 2006).

Para Gómez (2006), la coquetería se transforma a partir de los géneros, pero también a través de los procesos históricos como la libertad sexual, las formas de vestimenta como la minifalda, el uso de los pantalones para las mujeres y la libre elección de una pareja, elementos que han marcado pauta en las normas tradicionales de la seducción y el coqueteo. 
Dentro de la dinámica social del coqueteo se encuentra el lenguaje corporal, el cual es una guía para comprender la interacción, ya que el acercamiento físico o la exposición de ciertas partes del cuerpo son símbolos significantes como diría Mead (1973). Por lo tanto, todo depende de esas interpretaciones para entender si es amistad, una posible construcción de amor de pareja o encuentros solo sexuales. Para Ojeda y Avilés (2018), la constante comunicación (saber del otro), el repentino alejamiento, tener una comunicación intermitente o cancelar planes son "indicadores" para entender si se trata de una relación de pareja, sexual o amistosa.

Entonces, después del coqueteo y del surgimiento de una situación de un va y viene, "puede" generar la posibilidad de comenzar una relación de pareja, las indirectas se vuelven declaraciones amorosas y comienza otra dinámica dentro de la pareja, donde comúnmente se dice la frase: “qquieres ser mi novia/novio?” o "me gustaría salir contigo” así da inicio a otras acciones que consolidan la etapa de inicio del noviazgo. De acuerdo con el Diccionario de la Lengua Española (2019), el ligue es la acción de entablar relaciones amorosas; para Fernández (2017), en las interacciones sociales llevadas a cabo en el ámbito online, se usa el término Dating que significa "ligue" o "noviazgo" en el idioma inglés, así que se entiende el ligue como la manera de entablar relaciones de pareja.

Entonces, el coqueteo y el ligue "pueden" estar relacionados, siempre y cuando se acepten las acciones del otro para dar pauta al siguiente paso, que es establecer la relación de pareja.

Actualmente, tenemos a la mano un ámbito (Facebook) en el cual también se puede encontrar la coquetería, pero ¿de qué forma? Los "likes" y los "comentarios" van generando pautas de acción, dar un "like" o un "me encanta" a la foto de perfil se interpreta como un halago, como una forma de decir "me atraes físicamente", eso es para los usuarios una indicación de que "algo quiere" y es una forma para agregarse como "amigos" o iniciar conversaciones.

Así pues, Rodríguez y Rodríguez, (2016), Lasén y Puente, (2016) señalan que estamos ante un mundo virtual lleno de significados tan prospero como en el mundo offline; sin embargo, cada uno con sus respectivos códigos (la apariencia corporal, estrategias de seducción (miradas) y reglas de etiqueta como el saludo (dar la mano), por otro lado, dar like 
y escribir mensajes o comentarios en las fotos resaltando la atracción física) pueden estar en relación, ya que la apariencia física también es importante para establecer lazos afectivos.

\section{Construcción de la Intimidad}

Además, se construye la intimidad, ¿cómo? Para Esteinou (2017), es el conocimiento y comprensión profunda de la pareja y para que esto suceda se requiere de una interacción intensa donde se visualizan los aspectos emocionales, personales y sociales que solo pocos tienen acceso, se conoce a la otra persona desde un punto privilegiado que implica la conexión emocional. Cuando todo esto sucede, se genera la confianza ya que se sabe mucho de la otra persona y puede contribuir en la expectativa en el desarrollo de su relación. De acuerdo con la Real Academia Española (2019), el término confianza significa: con quien se tiene un trato íntimo o familiar, entonces, a través del conocimiento mutuo llegan a tener un trato en el cual pueden expresar lo que sienten, sus gustos o sus problemas.

\section{Medios de comunicación y relación de pareja}

En cuanto Giddens (citado en Yarto, 2009) visualiza una transformación en el tiempo y espacio en la iniciación y mantenimiento de la pareja y no estaba equivocado; la relación de pareja y los medios de comunicación tienen una estrecha vinculación, pues es la manera de expresar las emociones, de dar sentido a las prácticas sociales que sostienen el noviazgo por ejemplo, la carta y el teléfono fueron modificando el cortejo, el ligue y el coqueteo, las llamadas telefónicas constantes, escribir cartas de amor, ¿quién no ha enviado cartas de amor escritas a mano utilizando el correo para hacerlas llegar a su destino? ¿No suena eso romántico? (Portalatín, 2013).

El correo se ha transformado, con la invención del internet y plataformas como Yahoo, Gmail o Hotmail (actualmente Outlook) hacen posible enviar mensajes de texto de manera más rápida, en segundos son recibidos por el receptor, sin papel y pluma y sin líneas telefónicas fijas que interfieran en su creación o su llegada. Todo esto forma parte de las acciones de los novios, es decir, las llamadas o los mensajes de texto son requeridos para "saber" si la persona está al pendiente del otro, aunque el medio sea distinto, el sentido que tiene recibirlos se torna importante en el inicio o mantenimiento de la relación de pareja (Lasén y Puente, 2016). 
En nuestro presente las personas establecen relaciones a través de medios virtuales, creando una red de amigos, familia y conocidos más grande; la importancia de esta tecnología y su integración a nuestra vida social, sin duda ha modificado el establecimiento de las relaciones de pareja, no sólo para iniciarlas, si no mantenerlas, a tal punto de formar parte de la "realidad", rompiendo con esas pautas tradicionales de conocerse en persona (Rodríguez y Rodríguez, 2016; Rodríguez, 2012).

Ahora estos lazos afectivos pueden manifestarse y expresarse a través de las redes sociales como Facebook, ¿te suena la frase, "si no está en Facebook no existe”? o "¿a poco están en una relación? Y si los avances tecnológicos ya han modificado nuestras relaciones afectivas, como mencionan Lasén y Puente, (2016), Lasén, (2012), Roca, (2011) y Cornejo y Tapia (2011), ¿qué esperaremos de ellas? ¿Seguirán modificándose? Yo creo que sí, estamos en la era digital donde la conexión con otras personas se extiende y esto genera cuestiones de inseguridad, anonimato y control de lo que deseamos presentar ante los demás en las redes sociales, así como medidas de seguridad que ayuden a la sociabilidad; todo esto lo abordaré más adelante en el capítulo 3.

\section{Semántica del amor: Noviazgo en Facebook}

He abordado un poco de cómo elementos de la vida offline se sitúan en la vida online, si el recibimiento de llamadas y mensajes modifican las prácticas sociales dentro del noviazgo, ¿no pasará lo mismo con las etapas de ligue y de conquista en Facebook? Qué pasa con el famoso chaperón o el cupido que nos ayuda a conectarnos con alguien que deseamos conocer o al menos comenzar a conversar ¿será lo mismo? Es decir, hay prácticas sociales que dan sentido a las relaciones amorosas, y ¿estas cambian al ser llevadas a cabo en plataformas digitales? En Facebook conocer a alguien por tener amigos o gustos en común puede parecer un flechazo cibernético, posiblemente ya no hay un chaperón presencial, pero los usuarios agregados en nuestra cuenta pueden jugar un papel importante para conocer personas (Roca, 2011).

El amor de pareja es una construcción social, es decir, que toma sentidos y significados dependiendo del contexto social; cada época y tiempo concibe sus relaciones sociales. De acuerdo con Luhmann (citado de García y Sabido, 2017), la pareja construye sentidos a través de imágenes, discursos y símbolos a esto se le llama semántica del amor; estas prácticas y 
rituales sociales son construidos y aceptados para después ser concebidos como costumbres. Para Rom Harré (1982) iniciar el noviazgo es el episodio previo a casarse, para esto es necesario tener citas como ir al cine, cenar en un restaurante, ver películas en casa de alguno de los dos involucrados, compartir fechas especiales como San Valentín o Navidad. Al asumir el rol de novios, se generan pautas de acción como regalar flores o chocolates, hacer sentir importante al otro, todo esto acorde a lo que se establece como relación íntima, con el fin de conocerse antes del matrimonio y conocer el posible panorama que les espera si llegan a vivir juntos.

Pero ¿qué pasa cuando nos relacionamos a través de plataformas virtuales? Al no poder verse de manera física se opta por otras alternativas como charlar a través de las webcams o los chats, escribir aspectos sexuales a través de imágenes, vídeos y audios (todas esas acciones que impliquen el uso de internet con objetivos sexuales), a esto se le denomina cibersexo (Cabrales, 2019), pero el asunto aquí es ¿cómo se experimentan las afectividades establecidas por medio de Facebook? ¿Cuáles son esas prácticas sociales que consolidan y les dan sustento a estas relaciones afectivas? Para García y Sabido (2017), existen dos niveles de análisis en la comprensión de las relaciones de pareja, en primer lugar se encuentra la semántica social, la cual consiste en identificar y comprender los valores y normas (cómo conversar, qué decir, cómo tratar a la otra persona, cómo se presentan ante los otros, etc.), por otro lado, describir la situación, cómo se construyen y en dónde, en este caso, el tiempo y el espacio en las plataformas virtuales se experimentan de manera diferente, ahora es posible relacionarse sin compartir un espacio determinado, el tiempo de espera de respuesta es instantáneo, haciendo posible un contacto rápido y eficaz como si los encuentros fueran presenciales (como una conversación cara a cara donde se obtiene respuesta inmediata de lo que se dice o se expresa). Ante esto, es recomendable entender el medio en el cual se inician y se mantienen estas relaciones, y cómo se lleva a cabo el proceso de interacción entre la pareja y su entorno virtual, tomando en consideración que se trata de seres sociales con pensamientos construidos de manera social y presencial.

De acuerdo con Lásen y Puente (2016), los vínculos afectivos creados en Facebook son fluidos y móviles, por la inmediatez de la web, pero dejan huella, es decir, son materiales 
porque los usuarios que establecen una relación afectiva interactúan a través de mensajes por inbox, comentarios, fotografías, dar un "me gusta" a las publicaciones y todas esas acciones quedan almacenadas para posteriormente poder ser consultadas si así se desea.

Las conversaciones, los gestos, las impresiones que antes eran efímeros dentro de la sociabilidad cara cara adquieren una materialidad digital que puede ser revisada, leída y compartida posteriormente. Las afectividades y los sentimientos están inscritos en el lenguaje visual, tanto en los textos como en las imágenes. Es decir, un "me gusta" en una foto de perfil puede ser interpretado como un coqueteo, un interés especial por parte del otro, o simplemente un halago. Estas prácticas sociales generan hábitos, expectativas y obligaciones mutuas, se crean reglas de etiqueta, en este caso, la interpretación de ciertas acciones dentro de Facebook puede ser considerado un coqueteo, pero también acoso u hostigamiento (Lasén, y Puente, 2016). Entonces, ¿cómo nos entendemos y cómo se crea ese mundo de significado?

Para Sabido (2017), la manera de relacionarnos con los demás depende de la validación y negociación de esos códigos, cuáles se usan o cómo se entienden, por ejemplo, ¿cómo la pareja de novios genera significados? Hay que tener en claro que no se trata solo de compartir memes o imágenes, es más allá de eso, se necesita de sentidos compartidos los cuales solo llegan a comprenderse a partir de la interacción social bajo ciertas condiciones sociales, es decir, la construcción de la realidad genera un "nosotros" y un "otros". La intersubjetividad juega un papel importante en los entendidos que se van experimentando dentro de la red social como Facebook, nombrar nuestras experiencias construye realidades, se generan etiquetas sociales que con su uso se vuelven reconocibles. La afectividad, por ejemplo, tiene una semántica, por medio de la narración somos capaces de identificarla incluso en estos medios donde la presencia física se expresa por la vertiente visual, un comentario, un emoticón en forma de corazón o una imagen de un personaje animado que manda besos, pueden ser interpretados como coqueteo o interés.

El surgimiento del ciberespacio cambió la forma de comunicarnos, entrando a un ámbito nuevo posiblemente "un espacio sin reglas" donde la única manera de orientarnos es a partir de lo aprendido en la vida cotidiana, las normas de interacción presenciales son la guía para las formas de convivencia en este mundo virtual. 
En la red existen protocolos y reglas de convivencia que son negociados por los usuarios, lo que genera aceptación (Winocur, 2015). El espacio virtual participa en las relaciones íntimas, transformando los rituales de cortejo, de ligue y en las estrategias de seducción, construyendo los significados de estar en pareja, por ejemplo, de acuerdo con Rodríguez y Rodríguez (2016), la comunicación permanente se ha vuelto una de las prácticas cotidianas para entender el compromiso y el interés; asimismo, para poder comenzar una conversación y posteriormente una posible relación de noviazgo por este medio, los likes y los comentarios juegan un papel importante, pues facilitan la comunicación, es decir, acciones como dar un "me gusta" o comentar publicaciones, son juegos de sociabilidad dentro de este escenario.

No obstante esa comunicación puede crear otro tipo de discusión en los noviazgos, no responder a los mensajes de manera inmediata, dejar en visto o no dar "me gusta", crea conflictos, se interpreta como desinterés o infidelidad, entonces, la prueba de amor ahora en nuestros días es proporcionar a la pareja la contraseña de su cuenta en Facebook, interpretándose como muestra de confianza (Malagón, et al. 2014), sin embargo, esto también puede ser considerado como formas de control y violencia (Olías, 2015), en otras palabras, no todo es miel sobre hojuelas, la sensación de celos ahora se debe a los "me gusta", a los comentarios realizados, a las fotos compartidas ha modificado las relaciones sociales, las parejas piden eliminar ciertos contactos, mensajes o fotos de la cuenta del otro, creando así un mayor control de lo que se muestra en Facebook (Olías, 2015). Cabe mencionar que respecto a estas formas de violencia, no entraré en detalle, pues aunque considero su existencia, para este estudio solo se describirá el proceso (el surgimiento, inicio, mantenimiento y finalización) de las relaciones de pareja a través de Facebook, preguntando si existe alguna diferencia entre mujeres y los hombres al momento de usar esta red social como medio de interacción social.

La intimidad que se crea en Facebook por lo regular se lleva a cabo en el ámbito privado, es decir, en los mensajes en inbox, donde se comparten fotografías más íntimas como el famoso "Pack" (imágenes que muestran los genitales de la otra persona) un componente para los códigos de coqueteo, ligue e incluso para mantener relaciones sexuales, transformando la erotización, aunque como se mencionó anteriormente, compartir ese tipo 
de fotos puede ser considerado como acoso sexual o seducción (Lasén, 2012) ¿Cómo es esto? Bueno, se considera acoso sexual cuando una persona escribe mensajes públicos o privados (con connotación sexual y que vayan contra la integridad física o moral) hacia otra persona de una manera constante que altera su vida cotidiana (Salmerón, et al. 2013).

Así que se trata de un tema complejo en el cual es necesario entender la diferencia entre coqueteo y acoso sexual; para Gaytan (2009), el primer término se refiere a una interacción donde se reciben o se aceptan los comentarios o contactos físicos del otro, en otras palabras, hay un ambiente de reciprocidad y consentimiento mutuo, mientras en el segundo término solo se busca complacer el deseo de una de las partes dejando de lado lo que la otra persona piense o sienta.

\section{Amor fuera de la red: Primer encuentro}

Actualmente, con ayuda del mundo virtual y las redes sociales, se establecen con mayor frecuencia las relaciones de amistad o de noviazgo; los usuarios tienen la capacidad de transformar los usos y utilización de los medios de comunicación, y un ejemplo claro, es el uso de Facebook, cambiando el propósito del contacto con conocidos para abrir las puertas a los desconocidos, aunque con características en común (personas, zona de residencia, lugares visitados, gustos, etc.)

Establecer relaciones amorosas a través de redes sociales como Facebook, ha creado otra alternativa, sociabilizar con personas de otra cultura o idioma dando paso a las relaciones a distancia, donde surgen elementos como la construcción de un "yo" y la idea del control de la apariencia mediante la edición de las fotos mostradas o publicadas, ¿pero qué pasa cuándo después de esa convivencia llega el momento de interactuar de manera física?

De acuerdo con Eva Illouz (2007), la presencia física es fundamental para culminar esas relaciones afectivas, pues, aunque comiencen a partir de compartir y conocer sus gustos, sus pensamientos, sus ideas, sus rutinas, sus opiniones de manera virtual, no hay manera de reemplazar las afectividades y las emociones que se generan solo cuando se toca físicamente al ser amado.

Algunos de los casos donde las parejas logran hacer contacto físico, no quedan satisfechas ya que crean expectativas respecto a la imagen del otro, "no es igual al de la foto" 
"no se parece" es lo que comúnmente se dice, por lo tanto, rompe con esa idealización. Así pues, interactuar física como virtualmente ayudan en la construcción de la pareja (Illouz, 2007).

Posteriormente, entraré en más detalle sobre esta sociabilidad construida en Facebook, a continuación, haré un breve bosquejo de la transformación tecnológica que hace posible estas nuevas formas de interacción social. 


\section{CAPÍTULO 2. REDES SOCIALES CIBERNÉTICAS: UN ESPACIO PARA ESTABLECER NOVIAZGOS}

2.1. El uso cotidiano de la computadora y el teléfono móvil

El desarrollo de la tecnología ha modificado nuestras relaciones sociales, indudablemente. Años atrás no podíamos concebir nuestra comunicación sin contar con códigos postales y direcciones para enviar cartas por correo o contar con una línea de teléfono fija para conversar verbalmente con alguien. Ahora esto ha tomado otro rumbo, donde la inmediatez y la rapidez son importantes para la comunicación, pero ¿cómo ha sido este proceso de modificación de nuestras interacciones sociales con ayuda de la invención de la computadora portátil, el teléfono móvil y el ciberespacio?

\section{La computadora una herramienta laboral}

La computadora entró a nuestra vida en un largo proceso de transformación, adquiriendo características físicas que fueron familiares para nosotros, un monitor parecido a la televisión y un teclado similar al de una máquina de escribir generaron comodidad y familiaridad para ser incorporada rápidamente al hogar (Márquez, 2015). En un principio su único objetivo era la resolución de cálculos científicos, alejado de la idea de un uso global y ni pensar que pudieran ser instaladas en cada casa o lugar de trabajo, sin embargo, estas cuestiones fueron una realidad más adelante en la historia, pasando de una cultura del cálculo a la cultura de la simulación, es decir, usar la computadora para navegar e interactuar.

Para Márquez (2015), la revolución informática consiste en una relación entre el uso y su tamaño, los ordenadores transitaron de actividades científicas a la realización de tareas de oficina o escolares; así se crea la PC, capaz de ser instalada en casa u oficina y después se inventa la computadora portátil (laptop) para un fácil manejo y traslado.

Se ha explicado un poco de sus cambios físicos, pero ¿qué pasa con sus funciones, es decir los sofwares? Al principio, la computadora solo estaba diseñada para visualizar texto, pero su modificación fue tal que se hizo posible la visualización de imágenes, iconos y fotografías, propiciando una dinámica diferente para trabajar en ella; paralelamente, el desarrollo de las multitareas también contribuyó a este cambio, la realización de varias tareas 
no sólo al mismo tiempo, sino tareas que en un principio no se concebían como parte de ella, leer y responder correos electrónicos, escuchar música ya sea almacenada o por internet, escribir un documento, leer el contenido de un periódico o una revista digital, revisar y leer las actualizaciones de mis "amigos" en Facebook o en otra red social, etc., todo realizado simultáneamente.

Así entonces, nos ha facilitado la vida, convirtiéndose en una imprenta, biblioteca, diccionario, enciclopedia, radio, televisión, reloj, calculadora, libreta de notas, mensajes, llamadas, etc., como una navaja multiusos, donde es más económico comprar una computadora que estos dispositivos por separado (Carr, 2010).

En los últimos diez años, se han desarrollado las redes sociales como Facebook, Twitter, Instagram, YouTube (Rodríguez, 2017), y con ayuda de la evolución del teléfono celular tenemos mayor acceso a ellas, usándose para cuestiones de trabajo, en la escuela o como entretenimiento, en la vida cotidiana se ha vuelto común comprar un teléfono móvil de acuerdo al consejo de una persona cercana o debido a una publicidad convincente. Más personas se incorporan a este medio, junto con todas sus implicaciones, donde ya no es necesario contar con una computadora, si ahora el celular posee las mismas funciones (Chaves, 2017).

El teléfono también tiene un proceso de transformación, debido a la modificación y el desafío de la distancia; en su momento, el envío de cartas había sido fundamental para la comunicación a distancia, pero con la invención del telégrafo ya no era necesario esperar tanto para recibir respuesta de nuestro remitente, pero no fue hasta el surgimiento del teléfono, cuando la comunicación fue simultanea; estos inventos cambiaron la forma de relacionarnos a distancia, afectando nuestras relaciones sociales y sexuales (Christakis, y Fowler, 2010).

Sin embargo, esto solo es el comienzo de la era telefónica, se desplazaron las líneas fijas dando paso al teléfono móvil, donde la comunicación exclusivamente oral pasa a segundo término y comienza el apogeo de la escritura, la incorporación del internet y múltiples funciones (anteriormente solo accesibles para la computadora) lo modificó completamente, obteniendo una gran importancia en nuestra actualidad. 
De acuerdo con Márquez (2015) y Christakis y Fowler (2010), el teléfono móvil se convierte en un ordenador de bolsillo, debido a las múltiples tareas que podemos hacer en él y con la característica de ser transportado a todas partes, su fisionomía se adaptó a la vida urbana, cambiando su forma física, su tamaño y su peso.

Su costo también se ha ido modificando con el paso de los años, existen algunos con precios económicos y otros muy caros, todo depende de la marca y sus funciones, aunque el uso de cierta marca conlleva a la posición en el estatus social ¿a qué voy con esto?

Para Márquez (2015) y Reyes (2017), la construcción del sentido de pertenencia está relacionada con el uso de ciertas marcas como Apple, Motorola, Nokia, Samsung y Microsoft, es relevante, dime qué marca es tu celular y te diré quién eres, es decir, el consumo como prestigio. Es cierto que, en nuestros días, es muy fácil abrir una cuenta en Facebook o en otra red social, pero eso no significa que la conexión y el envío de mensajes se realicen portando la misma marca de teléfono; también esto genera distinción, inclusión y exclusión social.

Este aparato "habla" de las personas, por ende, se ha recurrido a darle una apariencia personalizada, el color estándar (negro) quedó atrás, teniendo acceso a una gran diversidad de colores y texturas, así como fundas de diferentes formas. Adaptando estilos de vida, gustos personales, sentido de las modas y creencias, convirtiéndose en un accesorio que hable de quién eres, es decir, confiere un valor simbólico y un estatus social (Reyes, 2017; Yarto, 2009).

El contenido de cada celular también es personalizado, es como si hablará de lo que somos o de lo que aparentamos ser. Sin embargo, esta singularidad se encuentra en discusión, pues se trata de modas, un fenómeno colectivo que a partir de la identificación y uso de ciertos accesorios como las fundas o los colores crean sentido de pertenencia, pero se encuentran en constante cambio dependiendo de la temporada o de los productos disponibles en el mercado (Márquez, 2015).

Sin duda alguna, el teléfono móvil es parte de la vida cotidiana, pues de acuerdo con el Instituto Nacional de Estadística y Geografía (INEGI, 2017), los usuarios de teléfonos celulares representan el $76 \%$ de la población mexicana y 3 de cada 4 cuentan con un teléfono 
inteligente (smarthphone); así que en México la mayoría de la población cuenta con un teléfono no solo para hablar o recibir mensajes si no para la realización de múltiples tareas; para Márquez (2015), el celular es considerado parte de nuestro cuerpo, como una extremidad más, y esto desde mi parecer tiene sentido, pues sin duda ya forma parte de nuestra vida social, podemos usarlo en cualquier momento, a la hora del desayuno, en la comida, en la cena, antes de dormir, en la escuela, en el trabajo, en el transporte público, en la casa, en el baño, en la habitación, en el avión, etc.

Las horas que pasamos en él han aumentado pues la forma de utilizarlo se ha diversificado, pasando de las llamadas, enviar y recibir mensajes, a conectarse a las redes sociales, compartir fotos, realizar compras online, leer diarios, buscar información, trabajar, etc. De acuerdo con Márquez, (2015), las conversaciones por teléfono han dejado de ser privadas, quedando expuestas algunos aspectos de índole personal restringidos para cualquier receptor.

Por otro lado, es frecuente ver a las personas tomarse fotos o grabando vídeos en cualquier lugar, para posteriormente ser compartidos en sus redes sociales, exponer dónde estuvieron o las actividades que realizaron durante el día, en otras palabras, el streaming (emisión en tiempo real) es posible debido al uso de estas redes sociales como Facebook, compartiendo el presente más allá de las distancias físicas (Blanco, 2014; Gurevich, 2016).

La invención del internet transformó el uso de estos artefactos tecnológicos, aumentado la diversidad de su uso, pero antes de describir esas transformaciones, es importante aclarar que son diferentes los términos internet y ciberespacio, el primero se refiere a la infraestructura física, es el aparato por el cual se llevan a cabo las funciones de navegación, por otro lado, el ciberespacio es la zona donde se realizan las actividades, donde se intercambia información, en otras palabras es el lugar donde existimos dentro del internet (Islas y Benassini, 2005).

Así pues, con el progreso del ordenador, fue posible la invención del internet y por ende el ciberespacio, en el cual podemos tener contacto con miles de millones de personas, desafiando el tiempo y el espacio físico, por otro lado, la realidad virtual toma fuerza, mucho más de lo que imaginamos (Márquez, 2015). Entonces, si tenemos contacto con más 
personas, ¿El internet ocasiona sustituir amistades cercanas por conexiones “débiles” con amigos distantes?

Para Miller, et al. (2018), la invención del teléfono fortaleció en su momento los vínculos sociales en lugar de debilitarlos. En nuestra actualidad, ya contamos con múltiples redes sociales como Facebook, Twitter, WhatsApp, Instagram, Snapchat, entre otras, que nos ayudan a la organización e interacción social, pues mediante los mensajes o publicaciones se convoca y se conoce gente (Christakis y Fowler, 2010). Aunque por otro lado, la información no llega a todas las personas debido a la escasa distribución de la conectividad de internet, pues existen comunidades del país donde se presenta un acceso desigual en los servicios, por ejemplo, en las zonas consideradas urbanas cerca del 71.2\% utilizan internet y en las zonas conocidas como rurales solo el 39.2\%, lo que indica que el acceso a la web es limitado (Steve, 2018). Entonces, es innegable la forma en cómo se difunde y discute la información, pero es un hecho que no llega a toda la población mexicana.

\subsection{Facebook una red universal}

No obstante, Facebook es una de las redes sociales más populares dependiendo del rango de edad, pues de acuerdo con Mediaclik (2018), el 25\% de los usuarios en Facebook tienen entre 16 y 24 años, por otra parte el $29 \%$ tienen entre 25 y 34 años, mientras que solo el 9\% tienen entre 55 a 64 años; Su popularidad se debe a su instalación previa en los teléfonos celulares, contando que el gran número de usuarios mexicanos cuenta con un Smartphone. La era del teléfono móvil es producto del capitalismo, de acuerdo con los resultados de la Encuesta Nacional sobre Disponibilidad y Uso de las Tecnologías de la Información en los Hogares 2017 (citado en Larocca, 2018), el 72.2\% de la población mexicana mayores a 6 años usa un teléfono móvil, y 8 de cada 10 de esos teléfonos son Smartphone, facilitando el acceso a vídeos, fotos, contestando mensajes o comentarios.

Entramos en la era de las actualizaciones que provocan inquietudes cuando no se encuentra en conexión de internet, se crean sensaciones de estar "fuera de", de no pertenencia a las tendencias y a las novedades, ya no se pueden ignorar las notificaciones; En esta red social charlamos, discutimos, presumimos y conocemos otras personas, compartimos y leemos información de múltiples índoles, leemos las notas en tendencia, escuchamos y vemos 
los videos musicales de nuestros cantantes favoritos, podemos formar grupos (páginas colectivas) de acuerdo a nuestros intereses o gustos, nos enteramos de los "likes" o las reacciones de nuestras publicaciones (Márquez, 2015). Asimismo, para Malagón et al. (2014), Castellanos (2015) y Bernal et al. (2015) las actividades que cotidianamente realizan los usuarios cuando establecen una pareja a través de Facebook es el envío de mensajes privados, publicaciones en los muros, revisión del perfil de la pareja, tomarse fotos juntos para después compartirlas públicamente.

\subsection{Si no está en Facebook no existe}

El ciberespacio ha dado pie a nuevas formas de sociabilidad, debido al amplio número de personas con las que ahora podemos conversar y relacionarnos, compartir información y organizarnos de forma colectiva, el incremento de vínculos a los que podemos acceder con sólo dar un clic en la pantalla (Christakis y Fowler, 2010).

Para Christakis y Fowler (2010), son las redes sociales como Facebook, las que permiten este tipo de actividades, su principal objetivo es el seguimiento de la vida offline (fuera de la red cibernética), donde se pretende el mantenimiento de las relaciones ya establecidas, trasladando nuestra lista de contactos del teléfono a esta aplicación; pero también es posible conocer y establecer conversaciones con otras personas que no se encuentren en nuestro círculo de amigos cercanos.

La dinámica consiste en publicar fotografías, vídeos, imágenes o textos para que los demás usuarios (amigos, como comúnmente se les denomina) conozcan pensamientos, ideas, posturas, acciones, actividades de las otras personas, creando un ambiente de manifestación de ideas y creencias. Actualmente, uno de los usos más habituales consiste en conocer personas fuera del rango local, alcanzando un nivel global, estableciendo relaciones de amistad y de pareja. De acuerdo con Rodríguez y Rodríguez (2016), la difusión de información personal se convierte en parte de esta red, que si no se manifiesta se generan interpretaciones como la inexistencia de eventos o relaciones sociales; ahora con el manejo del teléfono celular se puede construir una imagen positiva de nosotros mismos y exponer nuestra situación sentimental, donde las fotos son una muestra de no tener problemas y como almacenamiento de recuerdos; también son una forma de demostrar que se sienten bien juntos 
y se expone a los demás el inicio y mantenimiento de la relación (oficialidad de la pareja), mientras que los likes dados a esas fotos son considerados una forma de aprobación.

\section{La vida pública se vuelve más pública}

El acceso a la información personal es cada vez más fácil, compartir la vida pública es el objetivo fundamental de las redes sociales cibernéticas y más personas desconocidas pueden tener conocimiento de quiénes somos y de lo que hacemos, solo con formar parte de nuestro grupo de contactos. En pocas palabras, se vuelve más común la exteriorización de datos personales y fotografías, donde el usuario toma control de su contenido (Sabater, 2014).

Queda aclarar que en estos medios virtuales aún se preservan aspectos de la vida privada, es decir, ¿la intimidad se vuelve visible? ¿Facebook es un campo de exposición de la vida privada, de las emociones y de las intimidades? No, no todo lo que se publica es expuesto o compartido para que todos sus contactos lo vean, los mensajes en inbox son una herramienta de comunicación, ya sea utilizada para ligar o para interactuar. Dentro de lo público se encuentran las opiniones, los memes, las fotos de perfil o fotos en compañía de otras personas, por otro lado, dentro de lo privado están los acuerdos, las invitaciones, la confidencialidad, las fotos sexys, los packs, etc. (Sabater, 2014).

De acuerdo con algunas investigaciones (Castellanos, 2015; Andrade, et al. 2015; Bernal, et al., 2015), WhatsApp y Facebook son medios para la comunicación pública o privada, considerando el primero como parte de la información que no se comparte a todos; y por otra parte, el segundo como recurso donde se exponen las relaciones de pareja.

Para Sabater (2014), la vida pública expresada en redes sociales se debe al control que tenemos de lo que escribimos o subimos, se presenta la necesidad de exhibirse, la visibilidad toma importancia en la presentación con los otros, porque estamos ante un mundo de espectadores; pero antes de publicar cierto contenido pasa por el proceso de posproducción, es decir, se toman decisiones antes de exponer alguna fotografía, opinión, imagen o vídeo (Sánchez, 2015).

Los datos comunicados en Facebook permiten el reconocimiento y la localización, sin embargo, como ya se dijo no todos los aspectos de la vida están expuestos, por ejemplo, la información personal más compartida en redes sociales, es el primer nombre, el género, 
las fotos personales, las fotos de celebraciones públicas como cumpleaños, fiestas, graduaciones, mientras que la información menos expuesta es la religión, la ideología política y los problemas familiares (Sabater, 2014). Así pues, este sitio web no es un espacio donde nada se oculta. Por otro lado, es un medio asincrónico, donde los datos personales persisten durante mucho tiempo, en el discurso cotidiano se dice que se toman fotografías o comparten su ubicación porque es una forma de mantener el recuerdo, como una memoria digital. Las fotos compartidas en general son una forma de expresión, de mostrar las actividades cotidianas; para Rodríguez y Rodríguez (2016), se considera una manera fiable de guardar recuerdos y que otros puedan verlos, son la herramienta por la cual se expresan relaciones afectivas, haciéndolas "visibles" en esta plataforma virtual.

Si estamos ante esa búsqueda de la exhibición y reconocimiento, para Bernal et al. (2015), las relaciones de pareja que se expresan a través de Facebook serán blanco de críticas, porque a través de las publicaciones se trata de mostrar un tipo de amor ideal y la pareja ideal, en este caso, entonces, ¿qué piensan nuestros parientes cercanos que tenemos agregados en esta red social respecto a las relaciones afectivas que establecemos?, ¿afectará nuestra manera de concebir esas relaciones?

Espinoza y Rojas (2015), señalan que entre "mayor vinculación familiar menor el uso del Facebook para establecer relaciones de pareja; por lo tanto, menor sea la vinculación familiar resultará mejor opción para aceptar estas relaciones” ¿será así?, ¿importará lo que los demás piensen? Los comentarios, las reacciones, la difusión de fotos personales como de pareja validan las relaciones, validan un tipo de "yo", sabremos más adelante si mantener un vínculo afectivo muy estrecho con los padres disminuye el uso de Facebook para establecer relaciones amorosas. También Facebook es un medio acrónico donde muchas personas pueden acceder a esa información personal después de mucho tiempo de haberse publicado, es decir, hay una audiencia que tiene acceso a nuestra información y en cualquier momento puede llegar a ella (Cornejo y Tapia, 2011).

2.4. Mundo de significado: De los emoticones a los memes

El uso constante de estos mensajes de texto, modificó el lenguaje escrito, por ejemplo, la utilización de caracteres alfanuméricos (palabras combinadas con números): salu2; y los 
signos de puntuación como elementos en la expresión de emociones, dos puntos y la letra d mayúscula, significa una sonrisa “:D”, dos puntos y un medio paréntesis también significa una sonrisa “:)", etc.

El aspecto visual predomina en la comunicación a través de este medio virtual, transformando la manera de interactuar y de iniciar relaciones sociales, ahora es más común utilizar los emoticones o los emojis para expresar emociones o sentimientos, construyendo así significados compartidos por esta comunidad de usuarios. El intercambio simbólico se vuelve prioritariamente visual, el uso masivo de imágenes genera una cultura de las imágenes, donde se comparten sentidos y significados (Sánchez, 2015). De acuerdo con Toledo (2018), los caracteres de los que tenemos acceso en Facebook tienen una clasificación o tipología, existe una diferencia entre los emoticones y los emojis, los primeros son exclusivamente rostros que pretenden expresar emociones a partir de signos de puntuación, mientras que los segundos son pictogramas, es decir, figuras de animales, de edificios, figuras de caras, etc.
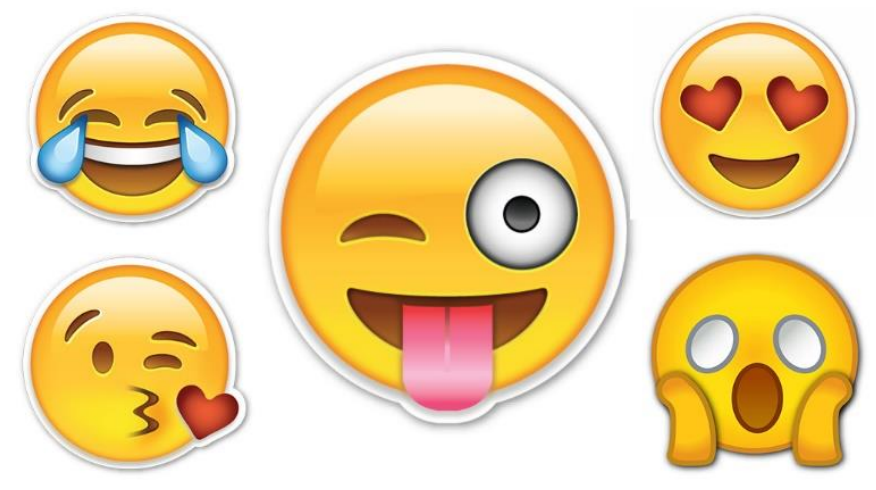

Imagen 1. Emojis

La invención de estas caritas o de estos gráficos se debe a la falta de la presencia física y a la velocidad con la que se recibe información. Los antecedentes provienen de los caracteres usados en Japón, que posteriormente se fueron modificando hasta llegar a ser lo que son ahora (Anexo 1).

Al pretender manifestar emociones de manera escrita, posteriormente esos códigos se transformaron en los emoticones con una forma más gráfica (caritas amarillas simulando el rostro humano), con el objetivo de recompensar la ausencia del cuerpo. En estos últimos años, ya no basta "mostrar" emociones con emoticones o emojis (imágenes estáticas), ahora 
la novedad está en el movimiento, es decir, los gifs, esas imágenes en movimiento que realizan acciones incrementan las opciones de narración o dar un punto de vista (Serrano, 2017). Pero el uso de las imágenes no paró ahí, el surgimiento de los memes ahora es un recurso para expresar opiniones o comentarios, sustituyendo un poco la escritura de textos. El uso de las imágenes va acorde con la inmediatez y simpleza a las que estamos acostumbrados cuando navegamos en el ciberespacio, por lo regular contienen un texto muy breve acompañados de una imagen, son interpretados y generan sentidos humorísticos, críticos o de broma.

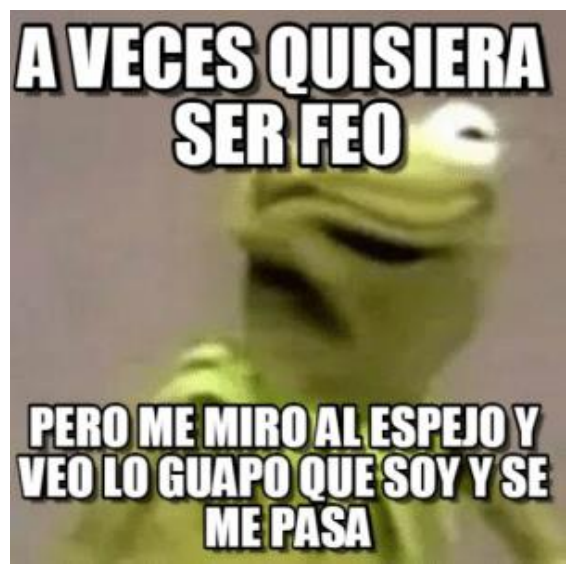

Imagen 2. Meme de la rana Rene

Los memes se han convertido en parte esencial para la expresión de ideas, creencias, gustos y pensamientos en redes sociales como Facebook, por lo tanto, este tipo de material visual, está relacionado con las condiciones históricas, es decir, para que sea entendido y compartido por los usuarios es indispensable que construyan significados, su sentido es cultural, burlarse de algo parte de nuestro acervo de conocimiento previamente construido por las relaciones sociales que establecemos en nuestro contexto. La forma de considerar si es debido o no burlarse de ciertos momentos de la vida cotidiana, se relaciona con nuestros valores morales.

Para Sánchez (2015), el uso de los memes tiene como característica resignificar el contenido de la imagen, es decir, se toma una imagen de algún acontecimiento de la vida cotidiana, de una película, caricatura o algún vídeo viral (popular), sin embargo, cuando se vuelve un meme cambia su significado, causando diferentes discusiones en Facebook, por lo tanto, se vuelve muy complejo y las imágenes dejan de ser un producto dirigido a la 
contemplación, construyendo la sociabilidad y la interpretación, en pocas palabras cuando se añade información se va re-significando, creando un espacio de subjetivación.

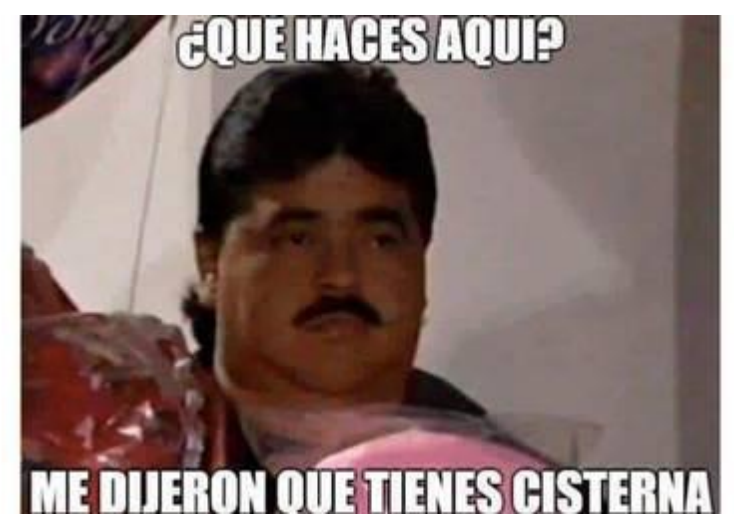

Imagen 3. Meme de "Choche"

Este meme se hizo viral (popular) en febrero de 2018, en el cual se muestra a un hombre (apodado "Choche" integrante del grupo musical mexicano "Bronco"), la escena muestra que trae consigo globos y un algodón de azúcar, acompañada de la pregunta "¿qué haces aquí?", esto podría ser aplicado a diversas situaciones, entre ellas el corte de agua potable que sufrió el Valle de México en octubre de 2018 (El sol de México, 2018), cambiando así su sentido, pues esta imagen corresponde a una escena de la telenovela mexicana Dos mujeres, un camino del año 1993, entonces, se saca de contexto y se construye la re-significación de la imagen como un tono de "burla" para hacer frente a la escases del suministro de agua potable que enfrentaban las familias mexicanas (Erizos, 2018).

Estamos ante la constante transformación del lenguaje escrito dentro de estas plataformas virtuales, y ejemplos clave son los emoticones, los emojis y los memes, una forma de expresar la vida offline (fuera de la red cibernética); por otro lado, existen comunidades dentro de grupos en Facebook quienes crean estos códigos para conocerse y compartir información, debido a esto son capaces de identificar a los nuevos integrantes, es decir, se crean reglas de interacción que ayudan a una comunicación eficiente aún sin mantener relaciones cara a cara. 


\section{CAPÍTULO 3. INTERSUBJETIVIDAD DIGITAL}

En este apartado hablaré más específicamente de las prácticas sociales que se llevan a cabo en Facebook, una descripción de lo que se hace o se espera en la sociabilidad virtual.

\subsection{El yo que siempre quise ser: Foto de perfil}

Relacionarse en Facebook es predominantemente visual, así que la apariencia es importante para el primer acercamiento a una conversación con alguien, es decir, la primera impresión es fundamental, la carta de presentación es la foto de perfil, en ella se muestra un "yo" que queremos mostrar a los demás, un "yo" construido a partir de filtros y posiciones en las que se toman las fotos, que más adelante obtendrán reacciones (me gusta, me encanta, me divierte, me enoja, me entristece) una modalidad que tiene esta red social para relacionarse con nuestros contactos; generando así una aceptación o rechazo de la apariencia física. Así que la presencia física es fundamental para entablar conversaciones y posteriormente crear lazos afectivos, esa corporalidad no pierde sentido en plataformas cibernéticas (Sabido, 2013; Illouz, 2007).

La foto de perfil como la información personal que se quiera, mostrar es sustancial para comenzar a interactuar, primero, se agrega a personas que se conocen en el ámbito físico (familiares, amigos de la escuela o del trabajo), después, con el paso del tiempo van apareciendo sugerencias de amigos, a partir de los contactos agregados. El ambiente es la biografía (el perfil), en ella se muestran la foto de perfil y la foto de biografía, siendo el primer acceso a la información de cada usuario. Por otro lado, se cuenta con la modalidad de cambiar la privacidad de cada una de las fotos de perfil, aunque para la sección de la biografía solo tienen como opción ser públicas.

Por lo general cada usuario cuenta con una foto de perfil, aunque no se pueda acceder a ella con darle clic, no obstante algunas cuentas no suben fotos personales y es más difícil conocer de quién se trata, incluso no es raro encontrarse estos casos.

Por otra parte, los filtros se han vuelto parte del proceso de subir fotos, modificando totalmente el aspecto, desde agrandar los ojos, cambiar el color de piel, ponerle marcos, adornos (estrellas, gafas, sombreros, orejas de animales, mejillas rosadas, pestañas, etc.); 
muchas veces los usuarios dudan de la apariencia de los otros en las fotografías de perfil, ¿al modificar el físico se está hablando de otra persona? No, solo cambia la representación de lo que se quiere mostrar a los demás, se expone la forma de vestirnos para agradar, pertenecer y ser parte de ciertos grupos sociales, es nuestro día a día, como dice el viejo dicho Cómo te ven te tratan (Pedroza, 2017).

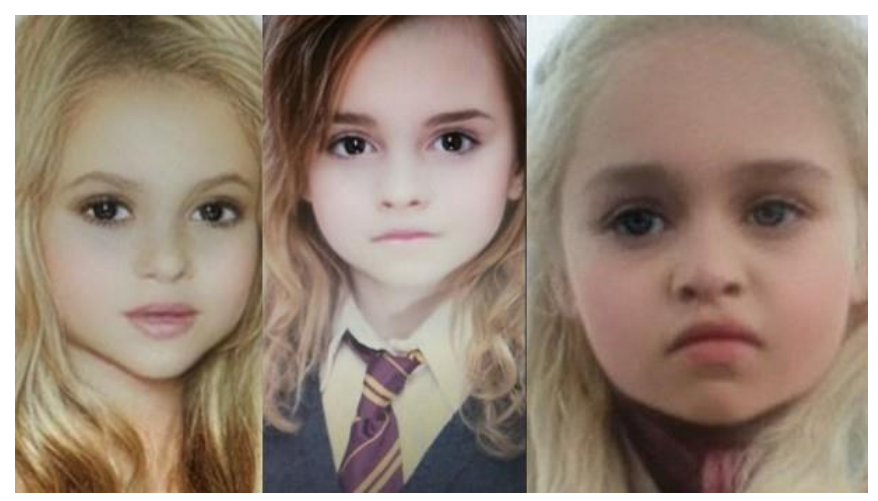

Imagen 4. Filtro de bebé

Por ejemplo, el filtro de bebé fue utilizado en el mes de mayo de este año (2019), y en Facebook como en otras redes sociales los usuarios publicaron sus fotos con este filtro, cambiando completamente su apariencia física; el origen del filtro se debe a la red social llamada Snapchat donde se tiene una gran variedad de opciones para cambiar las fotografías.

La presentación del "cuerpo" influye en nuestras relaciones sociales, esa apariencia creada de manera virtual no está fuera de lo establecido socialmente, al margen de los prejuicios y las normas morales presentes en este mundo "real", por lo tanto, si vemos a alguien "bonito" aun sea un avatar, será evaluado dependiendo de nuestro acervo cultural, categorizando así quién pertenece a los estándares de belleza (Christakis y Fowler, 2010). Al mostrar cierta apariencia o físico, se construyen identidades, para Tajfel (1981) la identidad social es el conocimiento que posee un individuo de que pertenece a determinados grupos sociales, conformado por una significación emocional y de valor, que generalmente tiene una connotación positiva y favorable, ese sistema de valores como se mencionó líneas arriba se construye socialmente (citado en Scandroglio, et al., 2008).

La fotografía tiene dos contextos de significación, lo estético y lo político, es decir, bajo qué criterios se comparten las fotos personales, qué es lo bonito para la sociedad a la 
que pertenecemos, qué posiciones o posturas son las "adecuadas", qué códigos sociales se siguen. Por otro lado, hay motivos por los que se comparten ciertas imágenes, qué quiero mostrar a los otros usuarios (Sánchez, 2015).

La representación del "yo" se construye a partir de la apariencia física, lo que piensan los demás de nosotros, asimilando características que "hablan" de nosotros, una persona bonita, fea, callada, expresiva, inteligente o tonta. La manera en cómo nos concebimos nos ayuda a interactuar, donde se busca el reconocimiento del otro. Estas plataformas virtuales favorecen el performance (Sánchez, 2015), re-significando la presencia física, es decir, se construye la imagen antes de ser mostrada a los demás, por ejemplo, en Facebook la foto de perfil se elige y la forma de editarla depende de los estándares de lo que se espera en las redes sociales.

\section{Las Selfies}

Con ayuda de Facebook, la manera de tomar las fotos compartidas en esta red social, sean para perfil, biografía o compartir como publicación, se han diversificado, a tal punto de tener un nombre y una interpretación para cada pose mostrada, por ejemplo, si la cámara se enfoca en los pies mientras y se ve en el fondo una televisión (como si estuviera relajado viendo la TV) se le denomina footie. Existen las fotos grupales, las cuales se enfocan en un grupo de personas en un mismo lugar mirando hacia la cámara; están las selfies clásicas, donde se hace énfasis en la cara de una persona mientras hay un fondo (otras personas o espacios públicos); también existe la selfie polifacética, una foto de cuerpo completo (con el objetivo de contemplar el físico de la persona) (Miller, et al., 2018); en otras palabras, el enfoque a una determinada zona del cuerpo es uno de los aspectos para "conocer" a la otra persona, mostrar solo la cara, el cuerpo completo, los brazos, los peinados, el maquillaje nos indican un lenguaje corporal exclusivo de las redes sociales, es decir, hay una intención de lo que se quiere mostrar a los demás ¿enfocarnos en ciertas partes que hablan de "lo que somos"?

El mundo virtual ha generado otras prácticas sociales, otra manera de presentación como lo son los filtros no solo para cubrir imperfecciones de la piel si no simular rostros completamente diferentes (Pedroza, 2017); estas nuevas formas de expresión corporal funcionan y son parte de lo que sucede no solo en Facebook si no en cualquier red social. 
En una red social como Facebook se construyen formas de hacer y de habitar el cuerpo, se crean reglas de etiqueta, y se visualiza la creatividad personal y colectiva (Lasén y Puente, 2016), es decir, los usuarios suben fotos de perfil de cierta manera porque es lo que van experimentando en su sociabilidad dentro del mundo virtual, ¿quién hubiera pensado en los filtros con características de orejas de perro, gato o conejo? ¿Por qué es común enfocar el rostro y no el cuerpo completo en la foto de perfil? Como dije, se construyen códigos de etiqueta, es decir, si dentro de la experiencia se presentan comentarios negativos en cierto tipo de fotos, se opta por subir otra; los comentarios de los demás forman pautas de acción para saber cómo considerar nuestro cuerpo en Facebook.

La intención de los usuarios por mostrar ciertas imágenes, bajo ciertos filtros se debe a cómo conciben los términos de belleza, que como había dicho anteriormente, la elección de ciertas fotos depende de su experiencia en el mundo virtual. Las fotos tienen diferentes significados, pueden mostrar un homenaje a una persona o una creencia, se refieren a una situación o un viaje, cambios de look, para seducir o llamar la atención de cierta persona o colectivo (Lasén, 2012).

Para Lasén, (2012), las fotografías son una forma de reconocimiento público, construye la idea de ser atractivo fuera de los cánones de belleza pues con ayuda de los filtros se cambian determinadas facciones y hasta se opta por cierto color de piel, y esto se debe a los comentarios y a las reacciones que se hacen o se ven en las redes sociales como Facebook, es decir, los otros usuarios ayudan a esa construcción de la imagen del yo; y de acuerdo con Rodríguez y Rodríguez (2016), en el noviazgo en Facebook, las fotos forman un elemento importante para la idealización de la otra persona, pues se busca una imagen positiva respecto al significado de la presencia.

\subsection{El anonimato: Soy o no soy}

Tener una cuenta de Facebook es muy fácil, sólo es cuestión de entrar a la página web, contar con un correo electrónico, contestar un formulario con preguntas personales como edad, sexo, número telefónico, país de residencia, etc. Pero estos datos pueden ser alterados cambiando completamente la apariencia física y los propósitos para contactar a otros usuarios. Sin duda, el uso de las redes sociales ha dado la posibilidad de construir 
nuestro yo como carta de presentación en este mundo virtual, sin embargo, estas posibilidades para cambiar de identidad pueden esconder intenciones, cayendo en el anonimato, no sabemos con quién hablamos y qué intenciones tiene al conversar e interactuar con nosotros.

Pero cabe recordar, que los propósitos y los engaños se viven también en offline (fuera de la red cibernética). México es uno de los países más violentos e inseguros del mundo, pero también es uno de los países (cuarto lugar a nivel mundial) con mayor uso de las redes sociales como Facebook, Twitter y WhatsApp, es un contexto hostil donde el narcotráfico, los feminicidios, los secuestros, la trata de blancas y los asaltos están a la orden del día, y es sensato pensar que las redes sociales también puedan ser usadas para estos fines; de acuerdo con el profesor Leobardo Hernández, maestro en Ciencias Computacionales por la Universidad Nacional Autónoma de México (citado en Excelsior, 2018), México es uno de los países que utiliza la información cibernética para cometer delitos como tráfico de órganos, secuestros, robos a vehículos y casa habitación, pornografía infantil y extorción, por lo que el $60 \%$ de los usuarios han sido víctimas de alguno de estos delitos.

Para Márquez (2015), el ciberespacio es divino, pero también malvado y diabólico, sin embargo, las actividades realizadas a través de estas plataformas virtuales son parte de la esencia humana, tal parece que trasladamos nuestros problemas, nuestras incertidumbres y nuestras inseguridades a este medio. Facebook es un ambiente inseguro donde las personas pueden controlar su imagen y su presentación, generando acoso, anonimato e incertidumbre de saber con quién nos comunicamos, pero depende del uso que se le dé, ya que es común recibir mensajes o solicitudes de personas desconocidas, las cuales no sabemos qué intención tienen, pero esto también se presenta en la vida presencial pues existe un control de lo que se quiere mostrar a los demás, siendo un punto a discutir.

Para Erving Goffman (citado en Rizo, 2011), en la interacción cara a cara, las personas llevan a cabo representaciones con el objetivo de controlar sus expresiones ante los demás (a partir del lenguaje verbal y corporal), entonces, estamos hablando de un proceso social que se presenta en la vida cotidiana y que la forma de comunicarnos y de representar nuestro "yo" es compleja. 


\section{Espionaje: ¿Stalkear?}

Debido a la posibilidad de ocultar cierta información de quienes somos, de quién se encuentra detrás del monitor, Facebook nos da la oportunidad de realizar acciones de espionaje, es decir, indagar en el perfil del otro, conocer la información que publica sin que se dé cuenta. Esta estrategia, actualmente es muy recurrida para iniciar una relación de pareja, pues a través de sus fotos, de sus "me gusta" y de sus comentarios dentro de su perfil, es posible construir la perspectiva de la persona. Se vuelve el medio para conocer previamente al otro, saber cómo son sus relaciones sociales, con quién tiene contacto, quiénes son sus familiares, amigos o su pareja (Rodríguez y Rodríguez, 2016; García y Enciso, 2014).

De acuerdo con Rodríguez y Rodríguez (2016), indagar la información de perfil del otro se ha vuelto una táctica para saber su vida cotidiana, se considera una herramienta para conocer lo mínimo del otro, esto se relaciona con la construcción del yo, al compartir información a los demás son capaces de crear su concepción de nosotros y esto puede ayudar en la primera etapa del cortejo y el ligue, porque expone la situación sentimental, se anuncia la propiedad (con quién sales), se marca territorio; al ser anunciado un noviazgo por Facebook se busca el reconocimiento y un lugar dentro de la vida sentimental de alguien. En pocas palabras, hay una audiencia (los usuarios) que reciben nuestra información, lo que orienta las interacciones sociales dentro de este medio.

\section{Medidas de seguridad ante el espionaje y el anonimato}

De acuerdo con lo anterior, en el ciberespacio específicamente en Facebook nos encontramos ante un mundo lleno de inseguridad, de encubrimiento, controlando la presencia, entonces, ¿qué hacer ante esos casos? Cuando se reciben solicitudes de amistad o mensajes de personas desconocidas, la aplicación de Facebook tiene varias opciones para restringir el acceso a tu cuenta usando el bloqueo o evitando que otras personas encuentren tu perfil (Maxmovil, 2018). Sobre estos temas no entraré en más detalles, pues aunque no se niega su existencia, no se abordarán a profundidad para esta investigación.

Nos encontramos en un mundo donde existen una gran cantidad de usuarios, que muchas veces no conocemos qué pretenden o qué buscan, por lo tanto, se opta por implementar medidas de seguridad que protejan de extorsiones, secuestros, etc., pues México 
en la vida offline está viviendo momentos complicados en temas de inseguridad y violencia, especialmente en jóvenes y mujeres.

3.3. Una mirada multidisciplinar: Relaciones de pareja a través de Facebook

Las preguntas que nos hacemos al momento de realizar y diseñar una investigación son las interrogantes respecto a ¿cómo se ha abordado el tema que me interesa indagar?, ¿desde qué perspectivas se ha estudiado? Y ¿cuáles son los hallazgos encontrados? Bueno, si bien el tema de las relaciones de pareja que se establecen a través de Facebook, no es un tema nuevo ni la primera vez abordado desde las ciencias sociales como la Psicología o la Comunicación Social, haré un pequeño bosquejo de los hallazgos encontrados en los diferentes estudios realizados en América Latina, con el propósito de tener un panorama general de los diferentes aspectos que conlleva este fenómeno social, así como dar cuenta de lo que pretende este estudio desde la Psicología Social.

Los estudios realizados a partir de la Psicología, están más enfocados en encontrar aspectos como la autoestima, los rasgos de personalidad orientados al uso de Facebook, los celos, la infidelidad y a "corroborar" el concepto de amor desarrollando sus etapas (Malagón et al., 2014; Espinoza y Rojas, 2015). Otro de los puntos a destacar es que comúnmente se pretende indagar la influencia que tiene Facebook para mantener la relación de pareja, es decir cómo su utilización repercute en el mantenimiento de las relaciones de pareja (Malagón, et al. 2014; Castellanos, 2015).

Por otra parte, también se han realizado estudios como los de Andrade, et al. (2015) y Malagón et al. (2014), los cuales exponen las ventajas y las desventajas de Facebook para el mantenimiento de la relación de pareja, haciendo énfasis en cómo se crean los celos, la desconfianza, la ansiedad y la infidelidad.

Metodológicamente hablando, los estudios abordan el tema a partir de instrumentos como las encuestas, por lo que, los llevan a cabo desde un procedimiento cuantitativo, con preguntas cerradas y considerando las frecuencias de las respuestas obtenidas. Los cuales a mí parecer dejan de lado la parte de la construcción de significados por parte de quién lo vive y lo experimenta. 
Por otro lado, para Cornejo y Tapia (2011), el concepto "relaciones" por lo regular es usado para referirse a los contactos establecidos cara a cara (físicamente), en cambio el término "conexiones" se utiliza para la descripción de los contactos virtuales a través de las redes sociales; la interacción puede llevarse a cabo en presencia física y/o a través de redes sociales cibernéticas, aunque ambos se necesitan para darle sentido a la vida social, a esas relaciones de pareja que se establecen en esta determinada plataforma.

En nuestros días, el uso de Facebook en México es cada vez más común, no solo por parte de los jóvenes, sino de un sector de la población como los jóvenes adultos, según estadísticas de Mediaclick, (2018), la red social que más usan las personas entre 18 y 44 años es Facebook, debido no solo a su popularidad, sino por ser considerada fácil de manejar, a través de ella las maneras tradicionales para comunicarnos, informarnos y presentarnos se han modificado, re-significando nuestras relaciones con los otros.

Estudios como los de Castellanos (2015), Andrade, et al. (2015), Malagón, et al. (2014) y Bernal, et al. (2015) han tomado como sujetos de estudio a estudiantes de universidades, tomando como justificación el origen de Facebook en este espacio académico. Así como también se considera a los jóvenes entre 18 y 25 años, es decir, la juventud toma relevancia para la investigación de este fenómeno social.

Nuestras actividades cotidianas se han modificado, es decir se genera otro orden social, esto es que pasamos alrededor de 8 horas navegando por internet al día, de acuerdo con el periódico El Economista (2018); la actividad más realizada es el uso de las redes sociales (83\%), en ellas realizamos distintas actividades como comunicarnos, informarnos, trabajar, comprar, jugar, leer y conectarnos con diferentes personas, viendo imágenes (memes), fotografías y vídeos, leyendo y escribiendo mensajes de texto en los chats.

Debido a este estilo de vida cambian las relaciones sociales del sujeto con los otros, consigo mismo (representación del yo) y la forma de concebir la vida social, en otras palabras, se comienza a interpretar el mundo, por ejemplo, según The Economic (2018), un tercio de los matrimonios americanos comenzaron su relación vía internet, por lo tanto, estas plataformas digitales generan una red simbólica y cultural, creando una conexión masiva desafiando el tiempo y el espacio. 
Las relaciones sociales que se establecen toman un nuevo nombre: conexiones, por ser múltiples, instantáneas y fáciles de crear, un nuevo espacio social se crea y con ello las prácticas sociales como el coqueteo, el ligue, el establecimiento de las relaciones de pareja toman otro rumbo, una cibercultura donde lo local se vuelve más global, y lo público más público. Los usuarios comienzan a crear vínculos afectivos a través de este medio, la incorporación a la vida cotidiana de estas nuevas tecnologías, hacen posible el contacto con los otros sujetos sociales, compartiendo y construyendo sus apariencias físicas, cayendo en un juego de apariencias, adornos y poses, se rompe con lo tradicional para darle paso a otras prácticas sociales dentro de la sociabilidad (Fuentes, 2010).

En el mundo digital, se toman decisiones ¿qué queremos mostrar? y ¿Para qué o para quién?, se puede considerar que estamos ante un actor social, donde se tiene la sensación de empoderamiento, de construir un perfil, un espacio que lo hace suyo para ser mostrado a los demás. Por supuesto que la sociabilidad a través de este medio es diferente si se compara con la forma presencial, sin embargo, se relacionan y se complementan, pues la preocupación de la apariencia física también es relevante tanto para el encuentro físico como virtual, pero la estética de las imágenes y de las fotos mostradas en Facebook, lleva otro proceso como los filtros y los adornos. De acuerdo con Sibila (citada en Fuentes, 2010), compartir gustos y pensamientos personales es una forma de espectacularización por la lógica de la construcción del yo, se muestran aspectos íntimos pero que siempre se termina escondiendo otros.

Por todo ello, estamos ante un ámbito donde se busca ser visto, buscado y conocido, es decir, el actor social tiene la capacidad de elegir qué mostrar, y aunque esta red es masiva, Facebook da la oportunidad de aceptar o seguir ciertas personas, creando así la idea de control, pero ¿realmente estamos ante la posibilidad de tener bajo control lo que hacemos, decimos y compartimos en estas plataformas digitales? ¿Qué se muestra para ligar, para coquetear? ¿Qué información se muestra para buscar e iniciar una relación de pareja? 


\section{CAPÍTULO 4. EL PENSAMIENTO SOCIAL SOBRE EL USO DE FACEBOOK COMO MEDIO PARA ESTABLECER RELACIONES DE PAREJA}

Para comprender la dinámica social presentada en Facebook, es importante considerar cuatro puntos importantes, por un lado, el lenguaje como el medio para expresar y construir realidades sociales, otro aspecto es el pensamiento social que surge a partir de la interacción y comunicación construyendo creencias, posturas y pautas de acción que se vuelven usuales en el mundo social; por otro lado, se encuentra la afectividad colectiva, la cual sostiene cómo los sentimientos o emociones se fundan también a partir de la interacción y sociabilidad con los otros; finalmente, están los sobreentendidos, los cuales exponen la idea de que para movernos y guiarnos en el mundo social, emergen reglas de convivencia y una lógica en las prácticas sociales que ayudan a comprender nuestras acciones y las de los demás.

Por lo tanto, para entender los significados, signos y sentidos que se crean sobre la relación de pareja iniciada a través de Facebook es necesario considerar lo antes mencionado, solo así podremos comprender qué es el coqueteo, qué es el amor, qué es el noviazgo y cuáles son sus prácticas sociales que lo inician, lo mantienen y lo finalizan en un mundo virtual, en una de las redes sociales más importantes del mundo, que en su inicio no estaba contemplada para crear lazos afectivos como este.

\subsection{Lenguaje}

De acuerdo con la Psicología Colectiva, el pensamiento se construye a través del lenguaje, es así como se crean realidades que le dan sentido a las personas en su vida cotidiana, para Pablo Fernández (2004), la sociedad es el pensamiento que la conoce, es decir, la sociedad crea realidades físicas o no físicas que ayudan a explicar esta vida social. Así

pues, por medio del lenguaje concebimos y construimos la realidad, nos ayuda a relacionarnos con los demás y a conocer las acciones que se realizan en la vida diaria.

En otras palabras, es la manera de acercarnos a esta dinámica social que vamos desarrollando desde nuestro nacimiento, entonces, si nos comunicamos de manera oral y escrita, ¿cómo se da este proceso?, ¿cómo llegamos a compartir entendidos dentro de nuestras interacciones sociales? y ¡cómo el uso de este lenguaje llega al terreno del ámbito online? 
La persona, a diferencia de los animales, pertenece a una estructura social, por lo que, su comunicación es diferente, se requiere un lenguaje más complejo más allá de las emociones y los instintos. Cuando se interactúa con otros, se crea sentido de pertenencia grupal o colectiva compartiendo significados y sentidos de la vida, constituyendo así un ser social.

El lenguaje verbal y escrito está conformado por signos y gestos, que le dan sentido a las diferentes acciones que realizamos dentro una interacción social. Para Mead (1973), la persona expresa gestos verbales y/o corporales (signos), que se complejizan cuando son compartidos por los otros, dando paso a la comprensión de la realidad social, a esto le llamó símbolos significantes.

A partir de esta situación social como el contexto cibernético, donde no están presentes los gestos corporales pero sí los escritos, que a su vez están en relación con los orales y "las conversaciones simbólicas", se ha construido un tipo de lenguaje visual, conformado por las imágenes y textos, así como también una serie de imágenes de rostros amarillos para expresar emociones e intenciones; y siguiendo con el planteamiento de Mead (1973), entenderemos que una de las funciones de los símbolos significantes en el acto social consiste en expresar emociones, significados e ideas, como los emoticones, los memes y las distintas formas de escribir textos en las publicaciones y las conversaciones del chat tienen el propósito de transmitir estados de ánimo, opiniones e intenciones.

Este lenguaje visual está compuesto también de fotografías y vídeos, los cuales ayudan a expresar la vida social de las personas, así como sus prácticas cotidianas, pero ¿cómo es el proceso de entendimiento y comprensión de esas innumerables expresiones visuales?

Para Mead (1973), cuando nos relacionamos con los otros seres sociales se generan experiencias que nos ayudarán como guía de acción en las diferentes circunstancias que enfrentemos en el mundo social, serán unidades de medida para entender qué es la amistad, qué es el amor, qué es el engaño, qué es la belleza, etc., por lo tanto, las condiciones sociales acompañadas del lenguaje son los medios para crear realidad y dar sentido a todo lo que hacemos, entonces, ¿cómo se comprenden las relaciones afectivas que se inician en esta plataforma virtual como Facebook? 
El significado de cada acción lo sabemos debido a nuestra sociabilidad previa en el mundo presencial, entonces, comprendemos cuando alguien está interesado sentimentalmente por alguien y cuáles son sus acciones que lo delatan. Para que estas relaciones compartan significados, es necesaria la capacidad de adoptar el papel del otro, hay que identifican las reglas, las normas y los gestos de los demás (el Mí, de acuerdo con Mead), que se hacen presentes en el acto social; es decir, en nuestra vida social presencial tenemos símbolos significantes como guía de interacción, que nos ayudan a entender qué es el coqueteo y qué es el interés de conocer a alguien, pero, ¿será lo mismo en Facebook?

Es evidente que no se cuenta con la parte física (de cierta manera), pero por medio de la escritura e imágenes (lenguaje visual) y prácticas sociales también se crean símbolos significantes, de acuerdo con la frecuencia con que se chatea, comentar en las publicaciones y el contenido de esos mensajes, comienza a construirse esos elementos que nos indican situaciones de coqueteo e iniciación de una relación de noviazgo.

Los usuarios de estas redes sociales han comenzado a transformar la comunicación social, convirtiéndose en significados comunes, y algunos hasta universales, es decir, el acto social como el coqueteo, compuesto por los elementos antes mencionados pueden ser entendibles para muchas personas en este mundo online.

De acuerdo con Lakoff y Jonhson (1998), las metáforas son una forma de lenguaje que nos ayudan a entendernos, comprender sentidos y dar significados, donde una imagen puede ser comprendida y compartida por los usuarios en las redes sociales, pero cuando existen personas que no la entienden se genera la idea de los otros, de los que están aparte. Es importante este sentido de inclusión y de exclusión, porque solo compartiendo significados es posible llegar a comunicarnos dentro de este mundo virtual.

Por otro lado, se encuentra la forma de concebir el amor mediante las metáforas, definiéndolo como un viaje hasta una relación de negocios (Rodríguez, 2012), a partir de la determinación lingüística dependiendo del contexto social y cultural, los pensamientos en el mundo social toman sentido, por ejemplo, si hablamos de una relación de negocios donde se invierte, se ahorra, se gana o se pierde nos estamos refiriendo al sistema capitalista ya que se trata de la vida cotidiana en la que vivimos. 
La comunicación por medio de las imágenes es fundamental en este espacio, el lenguaje escrito toma relevancia, sin embargo, no podemos dejar de lado que actualmente es posible compartir vídeos y hacer vídeollamadas, por lo tanto, lo visual y lo auditivo son herramientas muy usadas para difundir información. Los memes son un claro ejemplo de este recurso visual, una imagen acompañada de una escritura corta y fácil de comprender, lo que indica que estamos ante un mundo rápido y veloz, en el cual la lectura requiere cierta velocidad.

Las imágenes y el texto ahora son utilizados para crear y difundir opiniones e información, de una manera indirecta pero rápida. Estos memes también son utilizados en las conversaciones por chat ya sea en Facebook o WhatsApp ¿para qué escribir un texto si tengo la imagen perfecta que describe mi punto de vista o lo que deseo decir? Por lo tanto, ha tenido impacto en la dinámica del lenguaje escrito, transformándose con el tiempo.

\subsection{Pensamiento Social}

Hablar de cuándo exactamente el internet comenzó a realizar cambios en nuestras relaciones sociales, es difícil. De acuerdo con Fernández (2001), en el proceso de conocer a la sociedad y de cómo se construyen los pensamientos y las prácticas sociales, solo podemos comenzar a teorizar a partir de los efectos que ahora vemos. Durante la incorporación del uso del celular smarthphone y las redes sociales no fuimos capaces de ver cambios en las prácticas sociales, hasta que ya son notadas y toman relevancia en la vida social, entonces, las causas son explicadas después de los efectos.

Para teorizar cómo es que ahora son factibles y comúnmente usadas las redes sociales como medio para iniciar y mantener relaciones afectivas como el noviazgo, es necesario echar un vistazo hacia atrás, donde anteriormente la oralidad y posteriormente la escritura y la imprenta eran utilizadas para relacionarnos con los otros (Ong, 2016), pero si ya se incorporó el uso de estas nuevas tecnologías, ¿cómo fue que las aceptamos y por qué ahora es una alternativa muy recurrida para establecer relaciones afectivas?

La escritura a través del tiempo ha tomado mayor fuerza, la imprenta, la televisión y el internet abrieron paso a lo visual y textual, transformando nuestra manera de comunicarnos y relacionarnos, en el caso de las redes sociales cibernéticas como Facebook, todo el tiempo 
se escribe y se lee con ayuda de imágenes y textos y lo compartido es destinado a un público invisible; así que todo esto se trata de un proceso en la comunicación donde la escritura se interioriza en nuestra vida cotidiana, por lo tanto, la tecnología es otra forma de usar las palabras (Ong, 2016; Gordo, 2006), ¿Será que debido al uso continuo de estas redes nuestras relaciones cara a cara están siendo desplazadas? No se desplazan, las tecnologías son herramientas de comunicación (Gordo, 2006), son el espacio de la relación pues posibilita que las personas estén juntas, por ejemplo, cuando están fuera de su país o de casa la conexión a estas redes genera cercanía (Gil-Juárez, 2007).

Asimismo, para Pascual (2016) y Estébanez (2015), indagar en otros ámbitos de la vida cotidiana como los medios de comunicación (aunque este punto no se abordará en la investigación), es una ventana para conocer las formas de sociabilización y dan mensajes para entender qué es el amor en una cultura como la nuestra, por ejemplo, en las películas y las telenovelas transmitidas en televisión abierta o por cable, muestran cómo es el noviazgo heterosexual donde se busca un "y vivieron felices para siempre" y un amor romántico cargado de roles sociales a seguir.

De acuerdo con Arnheim, (1971), para comprender nuestra vida cotidiana es necesario el lenguaje, a través de él podemos acercarnos a los objetos físicos y no físicos que conforman nuestro entorno, por lo tanto, critica la idea de un naturalismo puro donde se sostiene la división entre el pensamiento y el lenguaje, es decir, cuestiona un mundo natural externo y defiende la postura de una realidad construida a partir de nuestras experiencias y el lenguaje activo que define y conceptualiza, así pues hemos construido a lo largo de la historia lo que significa que "es" el amor, que va de la mano con ciertas prácticas sociales como el llevar flores a la mujer amada, llevar serenata al pie de la ventada de su casa, tener salidas a ciertos lugares públicos, así como conocer a su familia, sin embargo, esto ha cambiado un poco debido a la incorporación de las nuevas tecnologías, en algunos casos ya no se conocen de manera presencial y sus citas se llevan a cabo a través aparatos electrónicos, transformando y reconstruyendo la concepción de las relaciones afectivas como el noviazgo, así como de igual manera cambia el significado de la presencia física.

Estas comunidades que se crean a partir de la interacción por vía internet, dejando de lado la parte física, se les denominan comunidades sociales abstractas, ya que no son directas 
pero que también comparten sentidos y significados de las situaciones sociales cotidianas, es decir, el tejido social y lo urbano se desarrollan en todas partes como en los medios tecnológicos (Piccini, 1996).

De acuerdo con Simmel (1908), nuestras relaciones sociales están mediadas también por los sentidos sensoriales, como una forma de lenguaje que construye significados sobre las prácticas sociales dentro de situaciones, así la parte física se vuelve importante en nuestra sociabilidad. En el mundo virtual, como en el mundo presencial se requiere de nuestros sentidos para comunicarnos e informarnos, la vista se vuelve relevante para comprender la información generada, la usamos para leer y apreciar las imágenes que se comparten en Facebook, es el acceso a la información cibernética, posteriormente recurrimos a los otros sentidos como el tacto y el oído, pues realizamos llamadas y videollamadas, vemos vídeos o imágenes con movimiento o sonido.

Las relaciones de noviazgo mantenidas en Facebook algunas veces optan por recursos tecnológicos para interactuar a través del tacto, por ejemplo, la creación de un dispositivo electrónico para besar diseñado por algunos científicos japoneses, la cual funciona por conexión USB y con ella ambas personas lejanas físicamente pueden posar sus labios y experimentar la sensación de ser besados (Expansión 2011), por lo tanto, la forma de concebir el cuerpo en este mundo virtual se ha ido transformando. En el conocimiento del otro, aun en el ciberespacio, los sentidos conforman el acceso a este mundo de sensaciones, de pensamientos y de prácticas sociales que le dan sentido a los encuentros amorosos.

Entonces, estamos cargados de todo eso que aprendemos durante la sociabilidad física, así que cuando la persona se encuentra frente a una computadora, eso aprendido se tomará como guía para interactuar en redes sociales como Facebook; para Mead (1973), a esto se le llama el Otro Generalizado, pues se necesita de los otros para comprender (en este caso) cómo es una relación de noviazgo y llevarla al mundo virtual.

Como seres sociales, tenemos esa capacidad de crear y transformar nuestro ambiente (para Mead se trata del $Y o$ ), y este es un claro ejemplo, hemos expresado nuestras creencias, costumbres, representaciones sociales, pensamientos sociales, prácticas sociales y acciones a este medio que parece tan efímero y aparente obstáculo para la interacción cara a cara, pero que ahora forma parte de nuestra realidad social. Como el contexto está en constante cambio, 
no sabemos hasta qué punto la tecnología formará parte de nuestra vida social, pero es un hecho que ha modificado nuestras relaciones interpersonales.

\subsection{Afectividad Colectiva}

Para Fernández (2000), un afecto, una emoción, una pasión o una sensación son todos sentimientos, es decir, todos son todos, y definir cada uno es un proceso del positivismo, ya que constituyen lo que las palabras no pueden alcanzar a explicar, son físicos, pero también son psíquicos. La afectividad es difusa y general, cuando se habla de amor se puede hablar de solidaridad, de felicidad, etc., en otras palabras, están relacionados por lo tanto, es complicado diferenciarlos.

Así pues, los sentimientos son objetos que no tienen nombre, y la única vía para comprenderlos un poco es por medio del lenguaje, pero este se queda corto, ya que se relacionan con una diversidad de elementos como lo vivencial, lo corporal y lo intuitivo. Entonces, las personas no se refieren a los sentimientos en sí cuando dicen cómo se sienten, si no que defienden ciertas determinaciones, es decir, "sabemos" qué es el amor, porque es lo que hemos construido a través de nuestras interacciones y lo hemos escuchado en los discursos que vemos en las películas de Disney o en frases célebres, ¿entonces el amor que experimentamos en el mundo virtual es parecido al experimentado en la vida presencial? Puede ser que sí, ya que como había comentado partimos de lo aprendido en la vida offline para interactuar y comprender algunos significados que se crean en Facebook, sin embargo,

párrafos más adelante desarrollaré la idea de que si vivimos el amor en el ciberespacio, la situación cambia y como dice Pablo Fernández (2000), los sentimientos son singulares debido a las situaciones que enfrentamos en la vida cotidiana.

Explicado lo anterior, las emociones, por lo regular se asocian al cuerpo, a procesos biológicos, pero desde una perspectiva construccionista (Gil-Juárez, 2002) nuestro sentir se construye de manera social, por lo tanto, el significado de la felicidad, la tristeza, la irá es acordado y negociado en la sociedad en la que vivimos, es decir, son las expresiones de los valores de un determinado contexto social, y ¿cómo se construyen?

Por medio del discurso, las palabras construyen sentidos, a través de ellas comprendemos a los otros, entendemos lo que significa estar enamorado ¿quién nos dijo que 
se siente tener mariposas en el estómago? Se debe a la negociación, a la creación de significados, y como se había señalado anteriormente, el poder del lenguaje para construir realidades tan indiscutibles para el ser social.

Tiene un lado pragmático, no se puede negar la participación del cuerpo, pues a través de él se expresan y se anuncian las emociones, pero las emociones son de origen social, porque se generan en las conversaciones, en la intersubjetividad, en el intercambio de significados y sentidos, reflexionando que el sentir individual no es íntimo y privado, pues es compartido dependiendo del contexto sociohistórico.

Para Pablo Fernández (1994), los sentimientos son válidos, correctos y admitidos debido a que son enunciados y son compartidos por todos en la vida cotidiana, es decir, los sentimientos se encuentran en los marcos del lenguaje. Siguiendo esta línea argumentativa, según Blondel (citado en Fernández, 1994), las pasiones, los afectos y los sentimientos están dictados por el pensamiento colectivo, es decir, hay una determinada sensibilidad debido a la cultura sentimental de cada sociedad.

Es decir, compartimos por medio del lenguaje lo que es estar enamorado, feliz, triste e incluso el dolor, etc., el lenguaje evoca, provoca y transmite los sentimientos, y en el mundo virtual compartir emoticones, expresiones faciales socialmente construidas como emociones ayuda a entendernos, ¿cómo sabemos que una cara con ojos en forma de corazones es estar enamorado o expresa amor? De acuerdo con Blondel (citado en Fernández, 1994), una vez definidas esas emociones se construyen patrones, los cuales servirán como guía en las interacciones sociales.

Las personas sienten de acuerdo a la colectividad, por ende, el lenguaje crea modelos de afectividad, posiblemente a través de los años, ya no se asociará la frase "siento mariposas en el estómago" al enamoramiento, transformándose así las emociones y su forma particular de definirlas y de sentirlas, en pocas palabras, cada contexto social construye una manera determinada de convenciones sentimentales (Fernández, 1994).

Por lo tanto, la afectividad es una entidad rodeada del lenguaje, pero como había señalado al principio, este no alcanza para comprenderla del todo, definir los sentimientos no es suficiente para conocer su esencia, para Pablo Fernández (2000) por muy tipificados que 
estén no se experimentan de la misma manera, así pues, las situaciones que conforman nuestra vida social son únicas y singulares. Entonces, los sentimientos son singulares, sociales y relativos, ya que son definidos por las personas durante el proceso de sociabilidad y no se experimentan de la misma manera porque cada situación en la vida cotidiana nos hace sentirlos de diferente manera.

Si estamos hablando que nos encontramos ante un mundo virtual donde se establecen y mantienen relaciones de noviazgo, y el sentimiento de amor se hace presente, sería interesante conocer cómo se construye esta emoción a través de un lenguaje visual y escrito, y que la única manera de orientarnos en este mundo es con ayuda de lo aprendido con anterioridad en las interacciones cara a cara ¿se construyen los conceptos de amor y de noviazgo de la misma manera en el espacio virtual como en el presencial?

\subsection{Sobreentendidos}

Peter Hofstatter fue un psicólogo social austriaco que en su obra Introducción a la Psicología Social (Hofstatter, 1966) abordo el término de los "sobreentendidos", los cuales se referían a esas acciones cotidianas que se convierten en lógicas, racionales y validas debido a su realización continua y como acuerdo dentro de los grupos sociales, es decir, se construye una dinámica social de interacción: qué se espera que se haga en determinadas circunstancias. La homogeneidad es una de sus características ya que esos entendidos o formas de comportarse o pensar son de uso común en un sistema social, convirtiéndose en la base para el entendimiento imponiendo pautas de acción.

En el mundo virtual aparentemente existe la noción de controlar la imagen pública y tener "libertad" de mostrar un "yo", a partir de diseñar tu propio perfil, pero está permeado por normas o reglas consolidadas, es decir, Facebook es un espacio con reglas y normas sociales creadas y validadas por los usuarios, donde cada uno de ellos participa en la construcción de una guía de interacción dentro de esta red social; así pues, se sabe qué fotos subir, qué información publicar y qué memes compartir.

Cada sociedad desarrolla sus entendidos (Hofstatter, 1966), para Facebook la dinámica de crear tu perfil, qué fotos (de todas las que se toman) se "debe" subir, si se muestra donde se vive y qué lugares se frecuentan, si se expresa que se tiene una relación de pareja 
con alguien y muchas pautas más, generan normas sociales, ¿cómo nos damos cuenta de que al recibir una solicitud de amistad no se trata de alguien que pretende secuestrarme o no es la persona que dice ser?

Esas orientaciones de seguridad, de "constatar" quién está detrás de cada perfil se desarrollan a partir de la experiencia propia y la de los demás usuarios; si vemos un perfil donde no se muestra fotos de personas, que oculta información personal, los amigos que tiene agregados y los lugares que frecuenta, aparte tiene un nombre de perfil con símbolos en otro idioma, es poco probable que se acepte, debido a que hay una lógica dentro de Facebook si muestra fotos e información de quién es la persona, es probable que sea alguien que no oculte quién es ni lo que hace.

Los sobreentendidos sirven para orientarnos en la vida cotidiana, qué modas o acciones "debemos" seguir para encajar o ser parte de colectivos; en Facebook hay tendencias y formas de uso, por ejemplo, el Messenger es llamado Inbox, los términos utilizados se van modificando. Ahora entendemos la palabra "crush" como ese amor idealizado o imposible (platónico) pues tal vez nunca se conozca físicamente o jamás se concrete una relación amorosa, sin embargo, gracias a las redes sociales se puede saber de la persona y de lo que hace cotidianamente (Checcori, et. al. 2017).

Otro concepto muy usado en estos momentos es el "pack", un tipo de fotografía donde se muestra hombres o mujeres posando con poca o nada de ropa y que posteriormente se envía a otra u otras personas (Santa, 2017), y por último, también se habla de "la barajita" que es cuando se pide en algún grupo de Facebook que cada integrante publique una foto acompañada de información personal con la finalidad de conocerse mejor entre esa comunidad (en el capítulo 6 se hablará con más detalle de este término); esos múltiples modos de referirse a las acciones sociales van construyendo entendidos que solo los usuarios pueden comprender y difundir a los demás.

Esas normas que creemos inquebrantables o inamovibles llegan a tener cambios y esos pequeños desvíos harán una nueva regla, es decir, los sobreentendidos están en constante cambio, emergen debido a la dinámica social, a la sociabilidad que comienzan a darle otro sentido a las nuevas acciones, por ejemplo, el modo de tomarse selfies, en algún momento era común tomarse fotografías en los baños, después fue cambiando. Subir una foto de cuerpo 
completo tiene cierto significado, subir fotos solo mostrando la cara y busto tienen otro sentido ¿cómo queremos que nos vean los demás?, ¿qué esperan de nosotros?, ¿bajo qué condiciones muestro mi relación de pareja, muestro los lugares a los que voy o expreso mis estados de ánimo?

Facebook es un ámbito donde acatamos las normas validadas, pero también experimentamos sus transformaciones muchas veces sin darnos cuenta, ya que en la actualidad no tener una cuenta de Facebook puede ser considerado fuera de la norma, un desviado que no se ha incorporado a la vida online.

Por otro lado, también tenemos sobrentendidos de cómo debe ser el amor de pareja, bajo qué condiciones e indicadores “debemos” guiarnos, qué pautas de acción hay que seguir sobre todo en este espacio virtual, donde se carece de contacto físico pero que la misma dinámica ha construido caminos para "recompensar" un poco esa ausencia, ¿qué se espera del otro cuando hay un interés amoroso, pero no pueden verse físicamente? Cuando logran verse físicamente ¿qué acciones hay que realizar?, ¿cómo mostrar afecto de manera pública y privada a través de Facebook?, ¿cómo se sabe que se está frente a un ligue o coqueteo?, ¿cómo sé que es mi novio o novia?

En nuestra vida cotidiana hemos aprendido y comprendido qué es el amor (acorde con esas transformaciones de pensamiento a través de los años) ya incorporado en esta red social, pues se consolidan acciones y se denominan las experiencias en el manejo de la cuenta de perfil y con ello se crean los sobreentendidos.

Esta investigación se interesa en esas formas de acción, comprender cómo se mueven las personas en Facebook, cómo expresan el amor de pareja, cómo lo entienden y por qué lo entienden, apoyados en el lenguaje visual y ¿por qué no? en los encuentros físicos, pero sobre todo conocer las prácticas sociales que se vuelven comunes y que conforman una guía en la interacción social. 


\section{CAPÍTULO 5. METODOLOGÍA}

5.1. Tipo de estudio

- Cualitativo

- Exploratorio

\subsection{Población}

Se entrevistó 4 hombres y 6 mujeres heterosexuales entre 21 a 43 años (pues de acuerdo con las estadísticas de Mediaclick, (2018) y We are social (2019), es el rango de edad con mayor porcentaje de usuarios que navegan en Facebook), que iniciaron un noviazgo a través de Facebook (que su pareja y ellos no se hayan conocido físicamente de manera previa y que su relación sea considerada noviazgo, es decir que esté presente el rol de novionovia). Estas características se tomaron en cuenta porque de acuerdo a lo señalado en el capítulo 1, este tipo de relación de pareja como el noviazgo heterosexual y guiado por el amor romántico, se ha ido transformando su sentido y su construcción; por otra parte, el por qué el inicio del noviazgo sea por medio de Facebook, es decir, no se hayan conocido previamente de manera física es por el papel que juega la presencia física para el primer encuentro, pues de acuerdo con Illouz (2007), la interacción cara a cara influye en el desarrollo de la relación.

Las personas entrevistadas fueron contactadas a través de otros contactos, es decir, amigos o conocidos me sugirieron a una persona que ellos conocían (bola de nieve), por otro lado, cuando termine esas entrevistas, opte por lanzar una convocatoria (Anexo 3), la cual exponía la búsqueda de personas que quisieran cooperar con el proyecto de investigación, así pues, les proporcione un correo electrónico para poder establecer una conversación y acordar la cita de la entrevista. Considero que las personas interesadas en participar en mi proyecto fueron pocas, y aun así pude concretar 10 entrevistas, no contando aquellos que no entraban en los criterios que necesitaba y los otros casos donde las citas no se concretaron (estas dificultades las abordaré en el apartado del procedimiento).

Finalmente, sobre el tema de la confidencialidad de los datos, a mis informantes antes de comenzar les preguntaba si estaban de acuerdo en ser grabados por audio, así como considerar exponer su nombre real o usar algún seudónimo (aunque al final se decidió no 
incluir las transcripciones completas como anexo, solo se visualizan fragmentos expuestos en el análisis $)^{2}$, por último, explique que la información otorgada se utilizará solo para fines de investigación, por lo tanto, ellos pueden disponer de una copia del escrito final si así lo desean.

\subsection{Herramientas}

- 10 Entrevistas estructuradas.

\subsection{Procedimiento}

Si entendemos que el contexto social, cultural, económico y político está en constante transformación, y con ello las relaciones sociales también atraviesan por cambios en las prácticas sociales, considero que como investigadora debo actualizarme en cuanto a la manera no solo de concebir al sujeto conocido, sino la forma de abordarlo, por lo tanto, haciendo uso de la entrevista estructurada me ayudará a dar un panorama más amplio del fenómeno, en otras palabras, conocer cómo ellos lo inician, cómo lo mantienen incluso como lo terminan, identificando los sentidos y los sobreentendidos que ellos construyen a través de Facebook.

También es importante situar mi objeto de estudio y a mis sujetos de estudio, comprender que se trata de un contexto mexicano, donde se habla español a la mexicana y que actualmente se ha incorporado en nuestra vida cotidiana el uso del teléfono móvil, por otro lado, estamos ante una situación de violencia e inseguridad donde se puede usar las redes sociales como medio para la extorsión, secuestro y robo.

En los meses de enero, febrero y marzo del presente año indague y contacte a las personas con las características que me interesaban. El número de entrevistas estructuradas fue en total de 10, 6 mujeres y 4 hombres, esto fue acorde a lo entendido como metodología cualitativa, el proceso de realización y escucha de las entrevistas para contemplar la

\footnotetext{
2 Esto se decidió porque al plantear el consentimiento informado, los participantes no querían hablar de situaciones muy íntimas (relaciones sexuales o el nombre de sus parejas), así que se optó por mencionar que toda la entrevista sería escuchada y leída solo por mi director de tesis (por ser quién revise que las entrevistas se hayan llevado a cabo correctamente) y por mí (por ser la entrevistadora). Entonces, no quise exponer su vida privada de manera explícita y completa.
} 
saturación teórica, es decir, si las entrevistas posteriores no agregaban elementos nuevos a la indagación, se vuelve un indicador para darle fin a la parte metodológica; Glaser y Strauss (citados en García y Manzano, 2010) señalan que los límites empíricos de los datos se presentan cuando el investigador ya no encuentra más información que contribuya al desarrollo de la investigación.

Sobre las conclusiones de mis notas de campo, por ejemplo, uno de los problemas que alcance a reflexionar se trata de mi poca eficacia para aclarar algunos detalles en las características (de mis informantes) expuestas en la convocatoria.

Pude darme cuenta lo extenso que es el tema y lo importante de acotar y especificar correctamente lo que quiero investigar, porque de lo contrario caigo en estos errores de inclusión, los cuales solían ser difusos para las personas, es decir, di por hecho que cuando escribí el criterio "hayas iniciado una relación de noviazgo por Facebook" se entendía a lo que me refería (ausencia física de manera previa) pero me encontré con 2 casos, en los cuales señalaban haber visto a la muchacha cara a cara y después la buscaron por Facebook, los cuales no incluí en el análisis, pues la primera atracción inició de este encuentro físico para después tener algún contacto o comenzar una conversación a través de redes sociales, recordemos que la construcción de la relación de noviazgo para esta investigación se enfoca en comprender la dinámica que se genera al buscar a la persona solo por Facebook y todo lo que acontece durante esa interacción meramente virtual, ya que se crean representaciones del "yo" a partir de las fotos y de la información personal que se comparte, generando incertidumbre o curiosidad de saber de quién se trata, donde vive y quiénes son las personas que lo rodean.

De lo contrario, si el primer contacto se da a través de un encuentro en algún lugar físico, entonces, se constata el género de la persona así como los lugares que quizá frecuenta eliminando un poco la cuestión del anonimato.

Me parece que las entrevistas se desarrollaron de buena manera a pesar de los contratiempos pues varias veces mis entrevistados postergaban las citas y en algunas ocasiones querían cambiarla para cierta fecha, pero justo en ese día ya tenía agendada otra. Durante la búsqueda noté que los hombres estaban menos interesados en contar estas 
cuestiones, ya que recibí muchas respuestas de mujeres. Esto se hace visible en el número de entrevistas realizadas (6 mujeres y 4 hombres).

Por otro lado, algunos de los hombres que entrevisté durante nuestra conversación observé comentarios curiosos, es decir, hablaban del comportamiento "típico" que tenemos las mujeres e incluso me trataban de dar consejos (se puede ver en las transcripciones). Considero que mi condición de ser mujer influyó en ellos, tanto empatía para las mujeres como el sexo opuesto para los hombres. Es decir, entrando en un estado de reflexividad como diría Bourdieu (2003), me hace pensar qué características tengo cómo persona, y cómo influyo en mis entrevistados y cómo ellos influyen en mí.

Decidí que mis informantes me indicaran el lugar óptimo para realizar la entrevista, exponiéndome a la inseguridad que enfrenta el país, sin embargo, no presente situaciones peligrosas. Aunque ir a Texcoco y Chalco fue complicado porque no sabía dónde me encontraba y teniendo en mente los peligros que enfrentan hoy en día las mujeres jóvenes, realmente lo pensé para trasladarme a ese tipo de lugares. Siempre trate de llegar temprano, y de despedirme a una hora adecuada, es decir, evitar caminar por las calles de la ciudad en la oscuridad. Eso me ayudó bastante por si me llegaba a perder o no encontraba el lugar que me señalaron y tener un retorno seguro a casa.

\subsection{Escenarios}

- Perfiles de Facebook

- Vida cotidiana

5.6. Tipo de análisis

- Cualitativo-interpretativo

- Exploratorio 


\section{CAPÍTULO 6. ANÁLISIS DE RESULTADOS}

Las características generales de las mujeres y los hombres entrevistados se encuentran en el Anexo 4.

\section{Interpretación de los códigos}

Antes de comenzar con el desarrollo del análisis, cabe señalar que, para la realización de las entrevistas, se utilizó un guión, el cual se encuentra en el Anexo 2, donde se aborda cada uno de los objetivos específicos y aspectos teóricos; por otro lado, momentos previos de comenzar cada una de ellas, se llevó a cabo el consentimiento informado de forma verbal, de esta manera se abrió paso a la grabación de voz ${ }^{3}$.

Así pues, después de recopilada la información de las entrevistas estructuradas a 10 participantes, 6 mujeres y 4 hombres que iniciaron un noviazgo a través de Facebook (que su pareja y ellos no se hayan conocido físicamente de manera previa y que su relación sea considerada noviazgo, es decir que esté presente el rol de novio-novia), se transcribieron para luego ser analizadas.

El programa ATLAS.ti (un programa de análisis cualitativo que permite crear y asociar códigos/etiquetas en textos como las transcripciones, para posteriormente, ser analizados de manera interpretativa o estadística (Gallardo, 2014)) se utilizó para importar la transcripción de cada entrevista y en cada respuesta se usó la codificación abierta, axial y selectiva (Strauss \& Corbin, 1990) (la lista de estos códigos se encuentra en el Anexo 5). Lo importante de la codificación radica en encontrar conexiones entre las diferentes partes de toda la información, por lo que, me apoyaré en el Análisis de Contenido Cualitativo, ya que es una técnica de investigación que pretende identificar temas, palabras o conceptos asociados para posteriormente obtener sentido (Brito, 2012). Entonces, se tomó 8 códigos (categorías) como base, para estructurar la comprensión del proceso de relación de pareja y sus ejes centrales (figura 1, Anexo 6).

\footnotetext{
${ }^{3}$ La razón del por qué se hizo el consentimiento antes de comenzar la grabación de voz, se debe a que mientras no se tenga autorización de ser grabados es necesario primero preguntarlo, y cómo ya se había acordado, no creí necesario repetirlo; asimismo, el por qué no les proporcione un documento para que lo firmaran, se debe a que en ocasiones se realizaron las entrevistas de manera virtual, ya que los participantes son residentes de otros estados de la República Mexicana.
} 
Estos códigos fueron considerados como ejes centrales porque marcan una Densidad (esto se refiere con qué otros están relacionados) de 9, 6, 5, 4 y 3, así que aunque no estén vinculados con diversos códigos, son relevantes en la explicación del proceso de la relación de pareja, pues marcan pautas de acción para el siguiente paso en la relación. Así entonces, se toman como referencia los siguientes códigos: Amor y la pareja, Otro cotidiano, Agregar amigos, Interacción, Inicio de la relación, Mantenimiento del noviazgo, Primer encuentro y Final de la relación (figura 2, Anexo 6).

Los datos obtenidos se construyeron en un primer momento a partir del análisis de contenido y posteriormente, se realizó un Mapa de Redes (con ayuda del programa Atlas-ti) para mostrar la vinculación entre códigos, con ello, se irán respondiendo las preguntas centrales de la presente investigación, así como visualizar el proceso de la relación de pareja.

Además, en los siguientes apartados, se muestran los fragmentos de cada entrevista, (con algunas figuras ubicadas en el Anexo 6), con el objetivo de simplificar y mostrar la información para su mayor entendimiento.

\section{1) CONCEPCIÓN DEL AMOR Y LA PAREJA}

\section{El Amor a través de Metáforas}

Cabe señalar que uno de los elementos preguntados en las entrevistas, fue conocer qué es el amor, porque dentro de nuestra interacción cotidiana cara a cara conocemos y compartimos la idea del amor como aquel sentimiento por el que se sostiene la relación de pareja (Finkel, et al., 2014), entonces, para estos participantes ¿qué es lo que piensan específicamente sobre esta emoción? Pues bien, comienza a partir de la dedicación, conocer al otro de manera íntima para crear confianza, es decir, se visualiza como un proceso de dedicación y conocimiento del otro, y esto se expresa a partir de Metáforas; de acuerdo con Lakoff y Jonhson (1998) manifestamos analogías para entender nuestra realidad, en este caso el amor puede ser una carrera universitaria, la profesión de un jardinero o un chef que invierte tiempo y dedicación a sus creaciones, o ser una estatua que al conocerla íntimamente se fracturan el encanto y la idealización, y acorde con esta evaluación, también se considera como probar una plancha (si está caliente). Los participantes usan estos recursos para entender y expresar qué es el amor: 


\begin{tabular}{|c|c|}
\hline Participante 1, Mujer & $\begin{array}{l}\text { "(...) esperar, paciencia porque en la maestría o en la universidad tienes que ser } \\
\text { paciente no sabemos lo que va a pasar, tienes que ir construyendo poco a poco, } \\
\text { comprometida en tus calificaciones, en las relaciones de irlo conociendo, ver } \\
\text { cuando está de buenas y cuando está de malas..." }\end{array}$ \\
\hline Participante 3 , Hombre & $\begin{array}{l}\text { “(...) yo si empiezo a andar con alguien la veo como una estatua, es perfecta, } \\
\text { totalmente perfecta para mí, (...) pero de repente (...) hay algo que quiebra esa } \\
\text { estatua y es una grieta que (...) hace más grietas pequeñas y empiezo a ver que } \\
\text { las personas ya no es como yo pensaba y es cuando yo decido terminar (...) yo } \\
\text { decía que era la táctica de la plancha, bueno no puedes tocar una plancha así } \\
\text { luego, luego, porque puede estar caliente, iba poquito a poquito, pregunta por } \\
\text { pregunta, y cada vez las preguntas acercaban más al punto y cada vez empezaba } \\
\text { más a cortejar...”. }\end{array}$ \\
\hline Participante 4, Hombre & $\begin{array}{l}\text { “(...) cómo un escritor escribe palabras es por amor a la escritura o a las } \\
\text { palabras, o sea una palabra puede contener quién sabe cuántos pensamientos, un } \\
\text { chef en sus platos le da amor o sea porque es algo que le gusta, algo que le nace, } \\
\text { un jardinero como quiere a sus plantas, las riega (...) eso, es amor, es... le das } \\
\text { todo ¿no? o sea le das todo a esa planta... (...) o sea que el amor contiene } \\
\text { dedicación (...) es un amor puro así como las mamás o sea tienen un bebé que no } \\
\text { sabe cómo va a ser pero ya se enamoraron de él, van a dar su vida así, como los } \\
\text { manantiales ¿no? pues es agua pura así (...) porque no es como de las personas } \\
\text { de que ves esa chica y me gusta su cara y quisieras conocerla ¿no? en este aspecto } \\
\text { fue al revés me gustó el cómo me trató a través de palabras...” }\end{array}$ \\
\hline
\end{tabular}

En este punto, la relación de pareja parte del gusto por alguien, pero conocerse es un paso dentro de la interacción, pues se invierte tiempo a lo que se ama, con ello se evalúa si puede darse o mantenerse el noviazgo, Otro ejemplo de esto, es lo mencionado por el participante 4, Hombre que después de conocer a su pareja a través de Facebook lo considera como algo "puro" ya que aún con la ausencia física conoce a la persona y siente amor por ella, todo de acuerdo con la forma en que interactúan y se conocen.

Como podemos observar en estos ejemplos, optan por definir el amor apoyándose en las metáforas, las cuales implican una idealización y lo que se espera de este sentimiento, entendiendo la interacción como generadora del amor. 
Concepción del amor y la pareja: ¿Qué se espera?

Ahora que ya hablamos respecto al concepto del amor a partir de metáforas, ¿cómo ellos consideran la pareja y este sentimiento llevados a la práctica? Como seres sociales establecemos y mantenemos relaciones con otras personas influyendo en la manera de concebir la realidad, es decir, gracias al otro generalizado (Mead, 1973) y al lenguaje que se comparte y se resignifica a través de la interacción social (Fernández, 2004), es como se comprende a que nos referimos con noviazgo, el amor y las prácticas sociales que conllevan.

Para Finkel, et al. (2014), a través de los años, como sociedad (o sociedades) hemos construido varios modelos de pareja, uno de ellos se da en el siglo XIX donde surge la idea del amor y el compañerismo, que da cabida a la construcción de la pasión y la experiencia sexual; y para 1965 hasta nuestros días, hemos pensado la relación de pareja para obtener autorealización, felicidad y satisfacción a través de la idea del amor y la construcción de la intimidad (conocer al otro), enmarcados por el individualismo y enfatizados en la autosuficiencia y autodeterminación como trayectoria del crecimiento personal.

De acuerdo con Gil-Juárez (2002) nuestro sentir se construye de manera social, pues el significado de las emociones es acordado y negociado en la sociedad en la que vivimos, es decir, son las expresiones de los valores de un determinado contexto social, ¿a qué voy con esto?

Los elementos arriba señalados están presentes en la narración de los entrevistados, haciendo referencia a la reciprocidad, la autorealización, satisfacción, fidelidad, confianza y felicidad como parte de lo que se espera en la relación de pareja y lo que consideran como "amor"; en otras palabras, este sentimiento se vuelve pragmático, porque se esperan ciertas acciones que "demuestran" qué es amor, acorde al contexto en el que vivimos:

\begin{tabular}{|c|l|}
\hline Participante 1, Mujer & $\begin{array}{l}\text { “(..) entonces, sería lealtad, fidelidad, comprensión, sinceridad, confianza, } \\
\text { comunicación y tal vez podría ser esperanza...” }\end{array}$ \\
\hline Participante 2, Mujer & $\begin{array}{l}\text { "(..) para mí el amor es convivir, dar un tiempo más con una persona que te } \\
\text { llamción tanto físicamente como psicológicamente y en alguien que } \\
\text { puedes confiar o puedes llegar a confiar...” }\end{array}$ \\
\hline Participante 4, Mujer & $\begin{array}{l}\text { "(...) el amor es más como el tenerse la confianza, el poder estar con una persona, } \\
\text { el saber que cuentas con esa persona siempre y sobre todo que hay fidelidad...." }\end{array}$ \\
\hline
\end{tabular}




\begin{tabular}{|c|c|}
\hline Participante 6, Mujer & $\begin{array}{l}\text { "(...) bueno debes tener mucha confianza y sentir mucho apoyo por parte de la } \\
\text { persona o con quién estés y sentirte a gusto más que nada, y que te guste como es } \\
\text { su personalidad y todas sus ideas." }\end{array}$ \\
\hline Participante 1, Hombre & “(...) Es pensar en la felicidad de esa persona en vez de la tuya...” \\
\hline Participante 2, hombre & $\begin{array}{l}\text { "(...) que sea fiel, que sea sincero, honesto, (...) el amor debería ser recíproco } \\
\text { para mi (...) englobado eso es el amor, lealtad, reciprocidad, cariño obviamente } \\
\text { también ser paciente, compañero, confidente..." }\end{array}$ \\
\hline Participante 3, Hombre & $\begin{array}{l}\text { "(...) es saber entender a tu pareja que entienda y que juntos sean una mejor } \\
\text { persona (...) yo digo que debes evolucionar con tu pareja..." }\end{array}$ \\
\hline Participante 4, Hombre & $\begin{array}{l}\text { "(...) el amor contiene dedicación, esfuerzo, paciencia, respeto todo eso o sea el } \\
\text { amor es todo..." }\end{array}$ \\
\hline
\end{tabular}

En general, se visualiza que para las y los participantes el amor se mantiene gracias a la confianza, al apoyo y paciencia, entonces, en la relación se busca un bienestar mientras comparten momentos, es decir, sentirse bien con la persona a través de la convivencia. Así entonces, ellos comprenden el amor acompañado de otros sentimientos y acciones, según lo señalado por Fernández (2000), las palabras ayudan a la expresión y comprensión de esas emociones, acompañadas de lo corporal, por lo tanto, el amor es psíquico, pero también físico a partir de la dedicación, de escuchar, apoyar, ser fiel, paciente, etc., nos "dicen" o "indican" que eso es amor.

\section{Diferencias (entre hombres y mujeres)}

Con base al cuadro anterior, hay diferencias entre los géneros; las mujeres enfatizan en la confianza, fidelidad y apoyo, es decir, consideran el amor como monógamo y exclusivo; estos elementos, les permiten tener una idea de una relación estable. Por otro lado, los hombres se centran en describir que el amor y las relaciones de pareja se basan en el respeto, la reciprocidad, la felicidad, la paciencia y una convivencia donde ambas partes mejoren como personas, pero no entran en detalle sobre la confianza o fidelidad.

\section{2) EL OTRO COTIDIANO}

Ahora bien, ¿cuál son los medios de partida para construir estas definiciones? Por una parte, se encuentran los medios de comunicación que emiten mensajes respecto a lo que se espera en el noviazgo (Estébanez, 2015), en este caso, el cine y la música son elementos para 
conocer qué es el amor romántico. Para el participante 3, Hombre, las maneras de interactuar en pareja se conocen a partir de las películas románticas y la música, en donde el amor es conceptualizado de manera diferente a través de los roles sociales, pues se considera a la mujer como emocional y sentimental, mientras que, los hombres pueden ocultar sus emociones:

\begin{tabular}{|l|l|}
\hline Participante 3, Hombre & $\begin{array}{l}\text { “(...) como que el romanticismo (...) yo conozco tanta música de amor o películas } \\
\text { de amor porque (...) yo congenio a veces más con las mujeres por esa parte, le } \\
\text { digo como que tengo mi lado femenino....” }\end{array}$ \\
\hline
\end{tabular}

El papel de la Madre

Entonces, por una parte se encuentran los medios de comunicación que nos dicen cuáles son las pautas de acción a seguir en la relación de noviazgo de acuerdo con el género al que se pertenece, pero ¿cuál es el otro medio que también influye en la construcción de esas ideas acerca del amor y lo que esperan de una pareja? ¿Y qué pasa cuando su noviazgo inicia y se mantiene a través de los medios virtuales como Facebook? Bueno, estas concepciones están construidas a partir de lo que ven y escuchan en su entorno (bajo un contexto socio histórico en específico); para los participantes de esta investigación lo que digan las personas cercanas como sus familiares, y en algunas ocasiones específicamente la mamá, la cual al mismo tiempo se encuentra dentro de una estructura social en la que difunde y comparte normas, reglas y costumbres, es relevante, pues de acuerdo con Espinoza y Rojas (2015), al tener una estrecha vinculación con sus familiares, la persona reconsidera este tipo de relaciones virtuales ¿pero por qué?

Retomando lo señalado por Finkel, et al. (2014), debido a ciertas transformaciones del pensamiento a través de los años, la idea del amor está relacionada con ciertas pautas de acción, como las citas y los encuentros cara a cara, pues recordemos que el cortejo se llevaba a cabo en espacios físicos como los bailes, el teatro y los restaurantes (en 1920); pero a partir del año 2004 surgen redes sociales cibernéticas como Facebook (Rodríguez, 2017), modificando así, la concepción de la interacción; de acuerdo con algunos participantes, su mamá presenta un rechazo a las relaciones online por esa falta de contacto físico: 


\begin{tabular}{|c|c|}
\hline Participante 4, Mujer & $\begin{array}{l}\text { "(...) "oye ma, pues ya no voy a regresar a Chile, ya se acabó" me dijo "que era } \\
\text { una buena idea que terminará la relación porque pues estaba muy difícil que yo } \\
\text { me fuera hasta allá." }\end{array}$ \\
\hline Participante 5, Mujer & $\begin{array}{l}\text { "(...) yo todo le contaba mi mamá, todo le decía (...) porque si yo quería que él } \\
\text { viniera necesitaba que mi mamá lo conociera, que le tuviera la confianza..." }\end{array}$ \\
\hline Participante 1 , Hombre & $\begin{array}{l}\text { “(...) mi mamá no le gustaba nuestra relación, mi mamá siempre se ha } \\
\text { preocupado mucho por nosotros, (...) es muy inteligente cuando dice "esa no te } \\
\text { queda, no te conviene", tiene razón... y cuando termine con ella me dijo "ya ves, } \\
\text { te dije” (...)" }\end{array}$ \\
\hline Participante 4, Hombre & 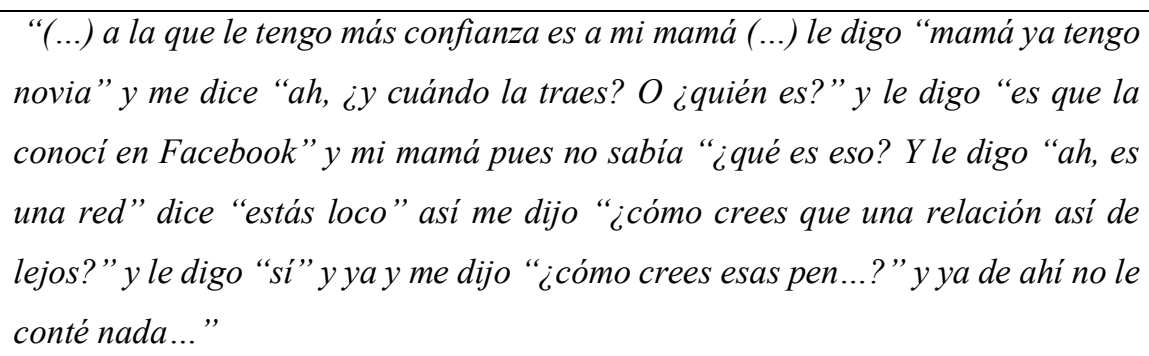 \\
\hline
\end{tabular}

El otro cotidiano (haciendo referencia al Otro generalizado de Mead) contribuye en la concepción de la relación de pareja, incluso crea dudas en su iniciación y continuación. Para los participantes sus relaciones interpersonales y sobre todo las más cercanas como la madre, son importantes en la toma de decisiones.

El papel de los Amigos

También se presentan comentarios por parte de los amigos, los cuales pueden tener una connotación alentadora o pesimista de la relación de pareja establecida a través de Facebook:

\begin{tabular}{|c|c|}
\hline Participante 1, Mujer & $\begin{array}{l}\text { "(...) pues con mis amigos son así, "iay qué bonito!, pues ojala que dure”, pero } \\
\text { hay otros que dicen, “¿y qué tal si tiene otra alla??”, (...) esa es como la } \\
\text { perspectiva que dan a veces..." }\end{array}$ \\
\hline Participante 2, Mujer & $\begin{array}{l}\text { "(...) mis amigos (...) de "ay, felicidades", (...) en ese entonces una de mis } \\
\text { mejores amigas me decía "ay, yo pensé que era su hermano" y le digo "no, no } \\
\text { manches, es mi novio"..." }\end{array}$ \\
\hline Participante 5, Mujer & $\begin{array}{l}\text { “(...) hablé con mi amiga y me decía "no, pues es un buen muchacho, todo está } \\
\text { bien, no pasa nada, tú sigue, si quieres seguir hablando, háblale”..." }\end{array}$ \\
\hline
\end{tabular}




\begin{tabular}{|c|c|}
\hline Participante 6, Mujer & $\begin{array}{l}\text { “(...) sí publicaban que "nos veíamos bien” o que "qué bueno que ya estábamos } \\
\text { juntos” y pues todos decian "ay anden”...", }\end{array}$ \\
\hline Part & “(...) me dijo una amiga "No, que una relación a distancia \\
\hline Parti & $\begin{array}{l}\text { "(...) me decian "ah, qué guapa” "ah qué bien” "hacen buena pareja” eran más } \\
\text { positivas..." }\end{array}$ \\
\hline Participante 3, Hombre & $\begin{array}{l}\text { "(...) una vez un amigo me preguntó “ ¿cómo le haces para hablar con tantas } \\
\text { chavas en Facebook? porque yo te veo que todos los trimestres has tenido una } \\
\text { novia diferente..." }\end{array}$ \\
\hline Participante 4, Hombre & $\begin{array}{l}\text { "(...) mi amiga me dijo "igual pues si a ti te gusta eso pues hazlo ¿no? pero yo } \\
\text { no creo que funcione”..." }\end{array}$ \\
\hline
\end{tabular}

\section{El papel de las Personas Cercanas}

Así pues, están ante una constante interacción con su contexto social (amigos, familiares y personas cercanas) que les dice qué considerar para iniciar y mantener una relación online, que mayoritariamente se concibe como una situación peligrosa y de engaño:

\begin{tabular}{|c|c|}
\hline Participante 1, Mujer & $\begin{array}{l}\text { "(...) alguna prima me va a decir que, ay pues felices los } 4 \text { pero, aun no conoce } \\
\text { la historia" }\end{array}$ \\
\hline Participante 2, Mujer & $\begin{array}{l}\text { "(...) hay unas personas que no creen "Ay, pero es que amor de lejos, felices los } \\
4 " . . . "\end{array}$ \\
\hline Participante 4, Mujer & $\begin{array}{l}\text { "(...) fue un reto porque mis papás no lo aceptaban todavía, o sea “ ¿cómo crees } \\
\text { que vas a ir a ese lugar? Si no conoces a nadie”..." }\end{array}$ \\
\hline Participante 5, Mujer & $\begin{array}{l}\text { “(...) cuando yo empecé a andar con mi novio en la preparatoria recibí } \\
\text { muchísima carrilla y de “que amor a distancia felices los } 4 \text { ”...” } \\
\text { “(...) quien no aceptó mi relación fue mi papá, fue muy difícil (...) me decía } \\
\text { “cómo va venir a esa persona si ni siquiera la conoces?” siempre fue lo mismo } \\
\text { “no lo conoces, no quiero que venga”...” }\end{array}$ \\
\hline Participante 1 , Hombre & $\begin{array}{l}\text { “(...) mis papás (...), siempre van a estar en contra de “no, es a distancia, ¿qué } \\
\text { vas a hacer hasta allá?"” y cuando termine con ella me dijo mi mamá "ya ves, te } \\
\text { dije” "la relación a distancia felices los } 4 \text { "..." }\end{array}$ \\
\hline Participante 2, Hombre & $\begin{array}{l}\text { “(...) el mismo grupito de amigos o de gente que conoces te perjudicaba tu } \\
\text { relación “Felices los } 4 ” y \text { “ ¿cómo sabes?” te metian dudas...” } \\
\text { “(...) ahora arraigado a lo que sus padres no me querían dejar verla...” }\end{array}$ \\
\hline
\end{tabular}


Esto repercute en lo que esperan en la relación, y como vimos anteriormente, la confianza y la fidelidad son importantes para mantener la relación (en el caso de las mujeres); la frase "felices los 4" se refiere a que si la pareja está alejada físicamente puede establecer otra relación sentimental o sexual, ocultando que podrían tener dos relaciones al mismo tiempo, considerándose esta actividad como infiel y pérdida de confianza.

\section{Relaciones Offline y Online}

Entonces, las relaciones online son cuestionadas, y ellos mismos interiorizan estos pensamientos. Por lo tanto, para las y los participantes la presencia física es requerida en una interacción virtual (por ejemplo, a través de vídeollamadas o quedarse de ver de manera física), ya sea para que no se presenten malos entendidos y/o como parte de la construcción de la intimidad (conocerse mutuamente):

\begin{tabular}{|c|c|}
\hline Participante 1, Mujer & $\begin{array}{l}\text { "(...) cuando estas platicando con alguien por WhatsApp, a veces se } \\
\text { malinterpretan las cosas (...) ya cuando se hace video llamada, al menos, ya } \\
\text { puedes ver los gestos con esa persona, no sé, es diferente..." }\end{array}$ \\
\hline Participante 3, Mujer & $\begin{array}{l}\text { "(...) él está a kilómetros (...) es un novio virtual, ni me toca, ni lo veo más que } \\
\text { cuando hacíamos vídeollamadas..." }\end{array}$ \\
\hline 6, Mujer & $\begin{array}{l}\text { "(...) creo que el enamoramiento o el amor de pareja, sí debe ser en persona, } \\
\text { convivir realmente ver realmente cómo es la persona, (...) a lo mejor sí cuando } \\
\text { estás hablando con ellos y no se conocen tú crees que es bonito y todo eso pero } \\
\text { ya cuando se conocen ya te das cuenta de cómo es en realidad..." }\end{array}$ \\
\hline Participante 2, Hombre & $\begin{array}{l}\text { “(...) igual si tienes una relación así no hay que quedarse nada más así de lejos } \\
\text { o de Facebook o virtual, etcétera, pero sí hay que quedarse de verse, si es como } \\
\text { que importante, la neta conocerse más..." }\end{array}$ \\
\hline Participante 3 , Hombre & $\begin{array}{l}\text { "(...) siempre es importante hablar pero también necesitas verte, no es como que } \\
\text { puedas vivir dos meses sin ver a una persona, pues como que no..." }\end{array}$ \\
\hline Participante 4, Hombre & $\begin{array}{l}\text { “(...) Cuando llegan los momentos duros de que quieres estar con ella... te } \\
\text { desesperas no estar ahí entonces yo creo que quieras o no, tal vez el aspecto físico } \\
\text { es algo importante en momentos (...) a mí parecer es que, es como cualquier otra } \\
\text { o sea tal vez la limitante te digo sea lo físico...” }\end{array}$ \\
\hline
\end{tabular}




\section{Diferencias (entre hombres y mujeres)}

En cuanto a la perspectiva entre géneros, las mujeres consideran las relaciones de pareja establecidas a través de Facebook diferentes a las que se establecen presencialmente, por esa falta de contacto y de presencia; en cambio, los hombres reconocen esa falta de presencia física pero mencionan que tanto las relaciones establecidas por Facebook como las presenciales son lo mismo, entendiéndose como un medio solo para comunicarse y que al final las relaciones interpersonales no pierden su esencia. En el cuadro siguiente se muestran las narraciones que ejemplifican estas diferencias:

\begin{tabular}{|c|c|}
\hline Participante 1, Mujer & $\begin{array}{l}\text { “(...) Pues, es que lo ves en tiempo real, es así como las llamadas, pues no es } \\
\text { lo mismo (...), de que puedes tocar a esa persona, molestarla, tocarle el cabello } \\
\text { (...) la interacción humana (...) ya con estas redes sociales ha modificado la } \\
\text { convivencia...” }\end{array}$ \\
\hline Participante 2, Mujer & $\begin{array}{l}\text { "(...) si te pueden enamorar con imágenes y mensajes bonitos pero ya en } \\
\text { persona le tomas importancia (...) si realmente era la persona que a lo mejor te } \\
\text { fue demostrando durante todo este tiempo de plática, todo este tiempo } \\
\text { virtual..." }\end{array}$ \\
\hline Participante 3, Mujer & $\begin{array}{l}\text { “(...) no qué flojera, lo bonito es estar con la persona, platicar así en vivo, salir } \\
\text { a pasear, salir al cine, a comer una paleta de hielo, eso es lo bonito..." }\end{array}$ \\
\hline Participante 6, Mujer & $\begin{array}{l}\text { "(...) prefiero conocer a las personas pues en persona, ver cómo se } \\
\text { comportan..." }\end{array}$ \\
\hline Participante 2, Hombre & $\begin{array}{l}\text { “(...) es igual, es lo mismo para mí, sí hay diferencias que no estés en el mismo } \\
\text { lugar geográfico pero en cuanto a comportamiento y demás no se me hacen tan } \\
\text { diferentes..." }\end{array}$ \\
\hline Participante 4, Hombre & $\begin{array}{l}\text { “(...) es lo mismo solo que sacrificas algo importante (...) pues no ves a la } \\
\text { persona física y te pierdes de muchas cosas físicas pero las emociones son } \\
\text { iguales, no cambian...” }\end{array}$ \\
\hline
\end{tabular}

Por otra parte, de acuerdo con las entrevistas realizadas, surge otro dato, es el hombre quién establece con más frecuencia relaciones afectivas a través de Facebook; si comparamos estas respuestas con lo que piensan sobre las relaciones online, entonces, entendemos que para los hombres es lo mismo, no tienen problema en establecer relaciones por este medio, en cambio, las mujeres como las visualizan diferentes a las offline, prefieren interactuar de manera presencial: 


\begin{tabular}{|c|c|}
\hline Participante 1, Mujer & $\begin{array}{l}\text { “(...) normalmente tengo relaciones, pues con personas que conozco en la vida } \\
\text { real..." }\end{array}$ \\
\hline Participante 4, Mujer & $\begin{array}{l}\text { "(...) fue como mi primer amor o mi primer ilusión, pero no volvería a tener una } \\
\text { relación a larga distancia...” }\end{array}$ \\
\hline Participante 5, Mujer & $\begin{array}{l}\text { "(...) fue el primero que acepte sin conocerlo (...) fue el primero en aceptarlo } \\
\text { como desconocido que me envió solicitud en Facebook y fue el primero en tener } \\
\text { una relación a distancia..." }\end{array}$ \\
\hline Participante 2, Hombre & $\begin{array}{l}\text { "(...) cómo te lo mencione pues si tuve, (...) del mismo México pero de otros } \\
\text { estados, he tenido novias de Puebla, Querétaro, Guadalajara, Tequila, ¿qué } \\
\text { otras? Se me está olvidando una, Zacatecas. (...)” }\end{array}$ \\
\hline Participante 3, Hombre & $\begin{array}{l}\text { "(...) ya estaba hablando con la segunda con la que iba a andar, cuando estaba } \\
\text { con la primera, después empecé hablar andar con la segunda ya hablaba con otra } \\
\text { chava, terminé con ella porque ya quería andar con otra chava..." }\end{array}$ \\
\hline
\end{tabular}

Para ilustrar todos los puntos señalados en estos primeros dos apartados sobre la conceptualización del Amor y la Pareja, y el Otro Cotidiano, se muestra la primera parte del Mapa de Redes (realizado y diseñado con ayuda del programa Atlas-ti), visualizando la vinculación entre los códigos:

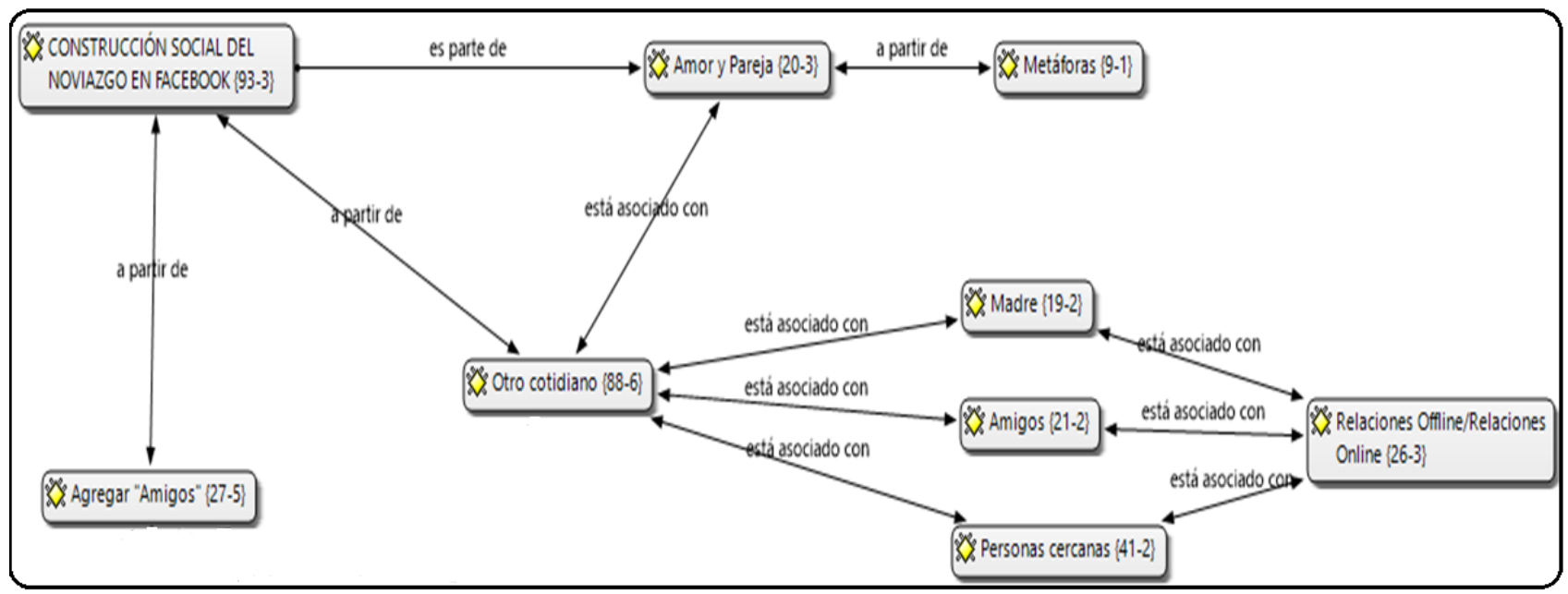

Figura 3. Mapa de Redes "Primera Parte: Construcción del pensamiento social"

Entonces, la construcción social del noviazgo en Facebook parte de la concepción que se tiene del amor y la pareja, de acuerdo con esto, entendemos lo que se quiere y se espera de esta relación afectiva. Los entrevistados se apoyan de metáforas haciendo hincapié en la evaluación de la interacción, pues es necesario invertir tiempo al otro para conocerse y sentir amor. Asimismo, estas concepciones difieren a partir del género, ya que las mujeres buscan 
fidelidad y confianza, en cambio, los hombres lo piensan a partir del respeto, la reciprocidad, la paciencia y mejorar como personas, pero ¿por qué sus pensamientos son diferentes? Recordemos que a partir del Otro Generalizado (medios de comunicación, familiares, amigos y personas cercanas), se genera una guía de acciones a seguir para entender que es un noviazgo y lo que se espera de cada género, como, por ejemplo, el sentimentalismo de las mujeres (al pensar en una relación monógama) y la experiencia de los hombres (tener relaciones reciprocas y pacientes). Por otra parte, si son los otros los que nos ayudan a construir pensamientos y posturas sobre el amor ¿qué se piensa de las relaciones de noviazgo iniciadas en Facebook? Los participantes se encuentran en un contexto socio histórico que compara la vida offline con la vida online, estando en contra de las segundas debido a esa falta de contacto físico, pues es parte "relevante" en la formación de lazos afectivos, es decir, el mundo virtual "trasgrede" las costumbres y tradiciones que los padres o personas cercanas tienen arraigadas; por lo que, esto influye en sus posturas respecto a aceptar o no noviazgos establecidos a través de Facebook.

\section{3) AGREGAR "AMIGOS"}

La primera concepción que se tiene sobre este tipo de relación está conformada de oposiciones en comparación con las relaciones offline, ¿qué pasa cuando se acepta el riesgo y cómo se va conformando la relación?, además, ¿cómo comprendemos este mundo virtual si lo aprendido se lleva a cabo en nuestras relaciones cara a cara? Bueno, se va aprendiendo a través de las experiencias propias y la de los demás, en otras palabras, vemos lo que los otros hacen, se crean los sobreentendidos (Hofstatter, 1966) como las reglas que se siguen en este ámbito virtual, por ejemplo, para los participantes lo qué se considera para aceptar o no a alguien como contacto o "agregarse" en Facebook se lleva a cabo bajo ciertos elementos, ya sea que se interactúe primero por un grupo (por lo regular de gustos musicales o personas de interés) o tengan personas o lugares en común; en el siguiente cuadro se exponen los fragmentos que ilustran lo comentado:

\begin{tabular}{|c|l|}
\hline Participante 1, Hombre & $\begin{array}{l}\text { “(...) A ella la conocí exactamente igual por Facebook, (...) fue por un grupo, } \\
\text { (...) empecé a hablar mucho con ella ...” }\end{array}$ \\
\hline Participante 6, Mujer & $\begin{array}{l}\text { "(...) pues si eran personas que tenían amigos en común de la escuela o de mi } \\
\text { familia o lo que sea sí los aceptaba...” }\end{array}$ \\
\hline
\end{tabular}




\begin{tabular}{|l|l|}
\hline Participante 3, Hombre & $\begin{array}{l}\text { "(...) me metía en los perfiles de mis amigos y veía su lista de amigos y decía "ah, } \\
\text { esta chava está bonita y es de la escuela” la agregaba..." }\end{array}$ \\
\hline
\end{tabular}

Entonces, existen 3 medios para agregar a alguien en Facebook: grupos/páginas, personas en común y lugares. Y de acuerdo con los 10 entrevistados, 6 de ellos conocieron a su pareja por medio de los grupos/páginas, mientras que 3 participantes su interacción comenzó por medio de amigos en común, y por último, 1 consideró los lugares físicos en común para establecer comunicación (figura 4, Anexo 6); por lo tanto, los entrevistados mencionan que recurren más a los grupos/páginas para comenzar la interacción y solo uno considera los lugares físicos como referencia, en seguida se muestran los fragmentos que visualizan las diferencias entre géneros.

\section{Diferencias (entre hombres y mujeres)}

La forma de comenzar la comunicación, en el caso de las mujeres mayoritariamente se da por medio de las publicaciones escritas en los grupos o páginas públicas, y en otros casos explicaron que la comunicación comenzó a partir de amigos en común; en cambio, los hombres inician la interacción a través de los grupos/páginas, de personas en común o a partir de compartir un espacio físico (figuras 5 y 6, Anexo 6).

\section{Grupos/Páginas de Facebook}

A continuación, se muestran los fragmentos de las entrevistas en las cuales los participantes señalaron los grupos/páginas de Facebook como medio inicial para la interacción y comunicación:

\begin{tabular}{|c|c|}
\hline Participante 1 , Mujer & $\begin{array}{l}\text { "(...) fue del grupo la Isla de Benshortiana, él hizo una publicación, (...) de que } \\
\text { él estaba en Guadalajara (...)” }\end{array}$ \\
\hline Participante 2, Mujer & $\begin{array}{l}\text { "(...) lo conocí por Lacrimosa, buscando la música de Lacrimosa, entonces, lo } \\
\text { agregue, creo que igual estaba en otro grupo, de otro foro del grupo (...)” }\end{array}$ \\
\hline Participante 3, Mujer & $\begin{array}{l}\text { "(...) eso fue porque me metí a una página que se llama "Cuarentones, } \\
\text { cincuentones, divorciados, solteros y viudos" ..." }\end{array}$ \\
\hline Participante 4, Mujer & $\begin{array}{l}\text { "(...) había un youtuber que nosotros seguíamos (...) entonces a los dos nos tenía } \\
\text { agregados en Facebook..." }\end{array}$ \\
\hline Participante 1, Hombre & "(...) de hecho yo estaba en un grupo de reggae..." \\
\hline
\end{tabular}




\begin{tabular}{|l|l|}
\hline Participante 2, Hombre & $\begin{array}{l}\text { "(...) estoy en un grupo, (...) de un cuate que es youtuber que se dedica a directos } \\
\text { en vivo..." }\end{array}$
\end{tabular}

\section{La "Barajita"}

Al mencionar los grupos o páginas públicas en Facebook, es necesario describir la dinámica que sucede dentro de este tipo de interacción virtual, como es el caso de solicitar que los seguidores publiquen sus fotos y proporcionen algunos datos personales para que esa comunidad en específico se conozca y así comience el primer acercamiento, a esta presentación de gustos acompañada de fotos se le denomina "Barajita", de acuerdo con la participante 2, Mujer:

\begin{tabular}{|l|l|}
\hline Participante 2, Mujer & $\begin{array}{l}\text { “(..) para estar ahi permanecer en el grupo pues tienes que poner una foto tuya } \\
\text { e ir diciendo qué es lo que te gusta, qué es lo que buscas, etc., ellas le llaman las } \\
\text { barajitas, "sube tu barajita si no te sacamos”...” }\end{array}$
\end{tabular}

\section{Likes y Comentarios}

Las fotos mostradas en los grupos/páginas son una forma de presentación (Pedroza, 2017), mientras los likes y los comentarios son parte de la primera interacción virtual (Rodríguez y Rodríguez, 2016); para los usuarios estas dinámicas conforman el inicio de la comunicación. El papel que juegan los "likes" y los comentarios de las publicaciones entre los administradores de las páginas y sus seguidores hacen posible la comunicación entre todos, ahí se da el momento de leer los comentarios, de revisar los "likes" y se entra a los perfiles para conocer de quién se trata; se observa la foto y los datos personales del perfil para después enviarle o aceptar la solicitud de amistad:

\begin{tabular}{|c|l|}
\hline Participante 1, Hombre & $\begin{array}{l}\text { “...) de hecho yo estaba en un grupo de reggae, (...) subí una foto que tengo y } \\
\text { ella le dio me gusta, en ese tiempo que no existían las reacciones y pues me mando } \\
\text { solitud...” }\end{array}$ \\
\hline Participante 2, Mujer & $\begin{array}{l}\text { (...) también le comenté en su foto me sentí de “bueno ya me lo comentó, yo se lo } \\
\text { comento” dije “ ¿quién será?” también me dio curiosidad “ ¿será del grupo o qué } \\
\text { onda? Pero sí vi que ya estaba su foto y su información por eso fue que seguimos } \\
\text { la plática..., }\end{array}$
\end{tabular}




\begin{tabular}{|c|c|}
\hline Participante 3, Mujer & $\begin{array}{l}\text { “(...) me metí a una página que se llama "Cuarentones, cincuentones, } \\
\text { divorciados, solteros y viudos" y yo subí una foto, "ay, qué guapa" (...) y ahí fue } \\
\text { donde me contactó esa persona, igual le di a su perfil y dije "Ah, mira ese cuate”, } \\
\text { en la foto que aparecía él dije "ay, qué guapo está el señor" entonces le regresé } \\
\text { "qué guapo se ve usted en esa foto" y así fue como inició todo..." }\end{array}$ \\
\hline
\end{tabular}

Hay formas de navegar en Facebook y se debe a la comprensión y difusión de normas sociales dentro de este mundo virtual, comienza la construcción del sentido de los "likes" como parte del interés hacia alguien, para Mead (1973) el Otro Generalizado, fundamos símbolos significantes que nos ayudan a entendernos dentro de la sociabilidad, en este caso Facebook tiene sus pautas de acción y un lenguaje construido a partir de reacciones ("me gusta", "me encanta", "me divierte", "me entristece", "me enoja") que ayudan al origen del interés y de la posible relación de pareja; también esto lo podemos teorizar a partir de los Sobreentendidos (Hofstatter, 1966), como esas normas sociales que seguimos para comprender las acciones de los otros, ¿cómo sé que le agrado?, ¿por qué le dio "like” a mi foto? Etc., esas acciones para ellos "refieren" a una atracción o interés, en otras palabras, comienza la coquetería (este tema se abordará a profundidad más adelante), se interpretan como un halago, una forma de decir "me atraes físicamente", eso es para los usuarios una indicación de que "algo quiere" y es una forma para agregarse como "amigos" o iniciar conversaciones:

\begin{tabular}{|l|l|}
\hline Participante 1, Hombre & $\begin{array}{l}\text { "(...) ella vio mi foto y le dio like, me mando solicitud, me mandó un mensaje y } \\
\text { me dijo que le parecía muy atractivo...." } \\
\text { “(...) para hacer notar mi atención, yo le empezaba a dar like a lo suyo, así fue } \\
\text { Participante 3, Hombre empezamos a salir y andar (...) veía que una chava le empezaba a dar } \\
\text { mucho "like” a mis cosas era porque la chava quería conocerme o quería platicar } \\
\text { (...), era como de "mira yo también te estoy hablando por aqui" y ya empezamos } \\
\text { a hablar..." }\end{array}$
\end{tabular}

\section{Personas en común}

Por otra parte, se encuentra el factor "las personas en común" para aceptar o no la solicitud de alguien, y esto está relacionado con la búsqueda de contactos y amistades, que a 
su vez es un elemento relevante para saber quién es la otra persona a partir de conocer de quién es amigo. Los siguientes fragmentos ilustran esto:

\begin{tabular}{|c|l|}
\hline Participante 5, Mujer & $\begin{array}{l}\text { “...) me dice (su novio) “es que miré fotos contigo y Michelle y me gustaste”... } \\
\text { te digo que me mandó solicitud (...) me dijo “si conocía a Michelle” y le dije "sí, } \\
\text { es mi mejor amiga”...” }\end{array}$ \\
\hline Participante 6, Mujer & $\begin{array}{l}\text { “...) yo aceptaba aunque no lo conociera pero pues si eran personas que tenían } \\
\text { amigon común de la escuela o de mi familia (...) teníamos amigos en común } \\
\text { porque íbamos en la misma escuela, solo que íbamos en turnos diferentes }(. . .) \text { yo } \\
\text { lo veía a veces de lejos y veía cómo era con sus amigos” }\end{array}$ \\
\hline Participante 4, Hombre & “...) yo agregué a su amiga (...) porque a mí, me gusta hacer amistades...”” \\
\hline
\end{tabular}

\section{Lugares}

Por último, se presenta el fragmento donde se consideró a los lugares físicos como una guía para iniciar una comunicación; aunque también el participante mencionó agregar a personas a partir de sus contactos, en otras palabras, se hace una combinación de ambas tácticas para conocer mujeres. Sin embargo, para él, el motivo por el que se elige agregar a alguien a partir de los lugares en común se debe a que si comparten un mismo espacio físico hace posible los encuentros presenciales:

\begin{tabular}{|l|l|}
\hline \multirow{5}{*}{ Participante 3, Hombre } & $\begin{array}{l}\text { “...) me salían sugerencias de personas que vivían ahí (...) yo vivía ahí en } \\
\text { Cuautitlán Izcalli... me metía en los perfiles de mis amigos y veía su lista de } \\
\text { amigos y decía “ah, esta chava está bonita y es de la escuela” la agregaba (...) } \\
\text { Nunca recomiendo el amor a distancia ese sí no (...) o sea que viva en otro estado } \\
\text { no, porque es importante hablar pero también necesitas verte....” }\end{array}$ \\
\hline
\end{tabular}

En Facebook conocer personas a través de grupos/páginas (gustos similares) o tener amigos o lugares en común puede propiciar un flechazo cibernético (Roca, 2011), como se había comentado en el capítulo 1, ya no hay un chaperón presencial, pero los usuarios agregados o los gustos juegan un papel relevante para iniciar o establecer relaciones interpersonales. 


\section{Diferencias (entre hombres y mujeres)}

Ahora, es oportuno hablar sobre las diferencias que se presentan entre hombres y mujeres, ya que aunque ambos pueden utilizar estas diferentes formas de enviar o aceptar solicitudes de amistad, pero de acuerdo a lo narrado por los participantes, la mayoría de los casos fueron los hombres quienes iniciaron la comunicación a través de los likes, comentarios y solicitudes de amistad (figuras 7 y 8, Anexo 6); si recordamos lo mencionado anteriormente, sobre la concepción del amor y la pareja, y las prácticas sociales que conllevan, tradicionalmente la idea amor romántico, mantiene que las mujeres son las pasivas y ligadas al sentimentalismo, en cambio, los hombres son activos y prácticos en sus relaciones afectivas o sexuales (Estébanez, 2015). Por lo tanto, esta pauta de acción se muestra en la primera interacción virtual:

\begin{tabular}{|c|c|}
\hline Participante 1, Mujer & $\begin{array}{l}\text { “(...) le había comentado en la publicación y empezamos así a interactuar y ya } \\
\text { fue cuando él me hablo’”...” }\end{array}$ \\
\hline Participante 2, Mujer & $\begin{array}{l}\text { "(...) de repente me llegó su solicitud de amistad y ya lo agregué (...) recuerdo } \\
\text { que él me dijo "Hola, ¿cómo estás? Veo que publicas tales canciones, ¿qué } \\
\text { música te gusta?”..." }\end{array}$ \\
\hline Participante 3, Mujer & $\begin{array}{l}\text { "(...) busqué a toda la gente que le dio like a la foto, ahí fue donde me contactó } \\
\text { esa persona (...) y me puso yo soy de acá (...) y después él me mandó solicitud, } \\
\text { yo sabía quién era, la acepté, y así empezó a ver publicaciones que yo subí y yo } \\
\text { de él...” }\end{array}$ \\
\hline Participante 4, Mujer & $\begin{array}{l}\text { "(...) él vio que yo le publique al youtuber y fue como de "ah, qué buena fan eres, } \\
\text { yo también lo admiro” y ahí fue cuando, pues me encontró y me agregó..." }\end{array}$ \\
\hline Participante 5, Mujer & "(...) Él fue el que me mandó la solicitud...” \\
\hline 6, Mujer & “(...) la verdad ni siquiera me acuerdo si yo lo agregue o él me agregó...” \\
\hline , Hombre & $\begin{array}{l}\text { "(...) me mandó solicitud (...) subí una foto que tengo y ella le dio me gusta, y } \\
\text { pues me mando solitud y me mandó un mensaje (...) y empezamos a platicar..." }\end{array}$ \\
\hline Participante 2, Hombre & $\begin{array}{l}\text { "(...) después de un directo vi que metieron a alguien al grupo y vi que era } \\
\text { argentina y dije "ah pues es de Argentina” (...) entonces ya vi su perfil su foto de } \\
\text { ella y todo eso, me pareció muy bonita (...) y dije "Ah, está bien bonita le voy a } \\
\text { hablar"..." }\end{array}$ \\
\hline Participante 3, Hombre & $\begin{array}{l}\text { "(...) me metía en los perfiles de mis amigos y veía su lista de amigos y decía "ah, } \\
\text { esta chava está bonita y es de la escuela” la agregaba (...) de repente ya veía "ha }\end{array}$ \\
\hline
\end{tabular}




\begin{tabular}{|l|l|}
\hline & $\begin{array}{l}\text { aceptado tu solicitud de Facebook" (...) y ya empezamos a hablar, bueno le } \\
\text { empezaba a mandar mensajes..." }\end{array}$ \\
\hline Participante 4, Hombre & $\begin{array}{l}\text { (...) y la agregué, y empecé a hablar con ella (...) le mande "hola, ¿tú eres amiga } \\
\text { de Michelle?" y dijo "ah, sí ya me habia hablado de ti”...." }\end{array}$ \\
\hline
\end{tabular}

\section{Stalkeo}

Pero antes de agregarse o de comenzar una conversación, se presenta el stalkeo, el cual se define como aquella revisión que se da a los perfiles ya sea parar mirar sus fotos o su información con la finalidad de saber quién es la persona (Quintana, 2016):

\begin{tabular}{|c|c|}
\hline Participante 2, Mujer & $\begin{array}{l}\text { "(...) si Perengano me mandó una solicitud revisó el perfil y veo si tiene más fotos } \\
\text { de esa persona..." }\end{array}$ \\
\hline Parti & $\begin{array}{l}\text { "(...) busqué a toda la gente que le dio like a la foto }(. . .) \text { le di a su perfil y dije } \\
\text { "Ah, mira ese cuate"..." }\end{array}$ \\
\hline Part & “(...) vi su foto y me gustó mucho dije "ah, e \\
\hline Participante 3 , Hombre & $\begin{array}{l}\text { “(...) me metía en los perfiles de mis amigos y veía su lista de amigos y decía "ah, } \\
\text { esta chava está bonita y es de la escuela” la agregaba...” }\end{array}$ \\
\hline Participante 4, Hombre & $\begin{array}{l}\text { "(...) yo agregué a su amiga, ya sabes "ah pues voy a buscar amigos”, (...) solo } \\
\text { me acuerdo que la agregué y que se me hizo bonita dije "se me hizo bonita, ah } \\
\text { vamos a agregarla”..." }\end{array}$ \\
\hline
\end{tabular}

\section{Diferencias (entre hombres y mujeres)}

Como podemos observar en el cuadro anterior, las 2 mujeres utilizan el "stalkeo" para conocer al usuario que le envío solicitud o le dio "like" a una de sus publicaciones, a través de evaluar su foto de perfil y su información personal; mientras los 3 hombres son quienes navegaban y revisan los perfiles para ver fotos y contactos, valorando a quién enviarle solicitud a partir de la foto de perfil y su aspecto físico (si la consideran "bonita"), entonces, se revisa los muros en cuestión y así se decide aceptar o mandar la solitud de amistad.

En otras palabras, mientras las chicas están interesadas por saber quién pretende tener comunicación con ellas, revisando los perfiles, los hombres son quienes evalúan las fotos (a partir de la apariencia física) y la información para después enviar solicitudes de amistad. 
Para Estébanez (2015), la relación de pareja está regida de pautas tradicionales de género, y en este caso, culturalmente son los hombres quienes toman la iniciativa.

\section{Fotos Públicas: Atracción Física, Cuentas Falsas y Cuentas Reales}

Como vemos, las fotos públicas son la carta de presentación, es decir, es el primer recurso con el que se cuenta para saber de la persona, tanto para evaluar su físico como para saber si es lo que dice ser. Retomando a Puma (2012), el atractivo físico es un elemento importante para la elección de pareja, así que este aspecto se relaciona con la evaluación de las fotos que los demás muestran o publican, para posteriormente comenzar la interacción y el coqueteo (del cual hablare más adelante):

\begin{tabular}{|l|l|}
\hline Participante 1, Hombre & $\begin{array}{l}\text { “...) ella vio mi foto y le dio like, me mando solicitud, me mandó un mensaje y } \\
\text { me dijo que le parecía muy atractivo.... }\end{array}$ \\
\hline
\end{tabular}

Igualmente si se evalúan las fotografías públicas ¿cómo se dan cuenta de que la persona es quién dice ser? De acuerdo con los participantes, para identificar una cuenta falsa se basan en las fotos y en la tipificación de las acciones, es decir, ellos dicen "una mujer hace esto", si realiza lo contrario es que la cuenta es falsa, entonces, por medio de las reglas o normas de género es que se guían ante este mundo lleno de posibilidades:

\begin{tabular}{|c|c|}
\hline Participante 2, Mujer & $\begin{array}{l}\text { "(...) reviso el perfil y veo si tiene fotos propias por así decirlo, si son puras } \\
\text { imágenes así como de tomadas de internet, no, mejor no los acepto..." }\end{array}$ \\
\hline Participante 1 , Hombre & $\begin{array}{l}\text { "(...) Yo puedo identificar perfiles falsos ¿cómo? Sus intenciones, una foto, la } \\
\text { forma en cómo te habla porque cuando es un perfil falso luego, luego "hola, } \\
\text { guapo, oye y esto, me gustas y me gustaría conocerte", es un perfil falso, es una } \\
\text { persona que te quiere extorsionar..." }\end{array}$ \\
\hline Participante 3 , Hombre & $\begin{array}{l}\text { (...) cuando un hombre se hace pasar como una mujer era tan obvio, porque me } \\
\text { empezaba a lanzar "hola, guapo" y decía "una niña jamás va a decir eso" (...) } \\
\text { me empezaban a comentar mis fotos de "guapo" y decia "ah, este es falso, no es } \\
\text { una chava, no era su Face" (...) y aparte ponían fotos hasta ... eran idiotas porque } \\
\text { ponían fotos de mujeres exuberantes y así en bikini y decía "esta mujer jamás me } \\
\text { agregaría en la vida obviamente"..." }\end{array}$ \\
\hline
\end{tabular}


La idea de "realidad" toma fuerza, para los usuarios es importante constatar de quién se trata y los recursos más acudidos son las fotos y la información. Se originan criterios para evaluar la información que se lee, una forma de guía para iniciar o no una interacción social "si lo veo "sospechoso", me alejo" porque ya se comprendieron los elementos que hay que tomar en cuenta para agregar o no a alguien; a continuación, como podemos observar ambos géneros toman sus precauciones al momento de agregar a alguien:

\begin{tabular}{|l|l|}
\hline Participante 2, Mujer & $\begin{array}{l}\text { “...) yo siempre antes de agregar una persona analizó todo el perfil, fotos si } \\
\text { realmente es esa persona si no termino la interacción y la comunicación, me voy } \\
\text { distanciando...” }\end{array}$ \\
\hline
\end{tabular}

\section{Afectividad Colectiva (Emociones)}

Asimismo, en este proceso, se experimentan emociones. Para Blondel (citado en Fernández, 1994), las pasiones, los afectos y los sentimientos están dictados por una determinada sensibilidad de acuerdo a la cultura sentimental de cada sociedad; en este caso, la primera emoción que sienten es el miedo, porque estamos ante una sociedad donde la delincuencia, los secuestros y la violencia están presentes (citado en Excelsior, 2018), esto los hace pensar en la incertidumbre de no saber de quién se trata y cuáles son sus intenciones, sin embargo, esto va cambiando conforme se lleva la conversación, pues la construcción de la confianza y la intimidad genera un conocimiento del otro y lo que le rodea (este punto lo abordaré en el siguiente apartado):

\begin{tabular}{|c|c|}
\hline \multirow{2}{*}{ Participante 5, Mujer } & $\begin{array}{c}\text { “...) Pues tuve miedo, porque pues como te digo era la primera persona que } \\
\text { decidi aceptarla que no conocía..." }\end{array}$ \\
\hline
\end{tabular}


Ahora se muestra la siguiente parte del Mapa de Redes para observar la vinculación de los códigos de este apartado (Agregar "Amigos"):

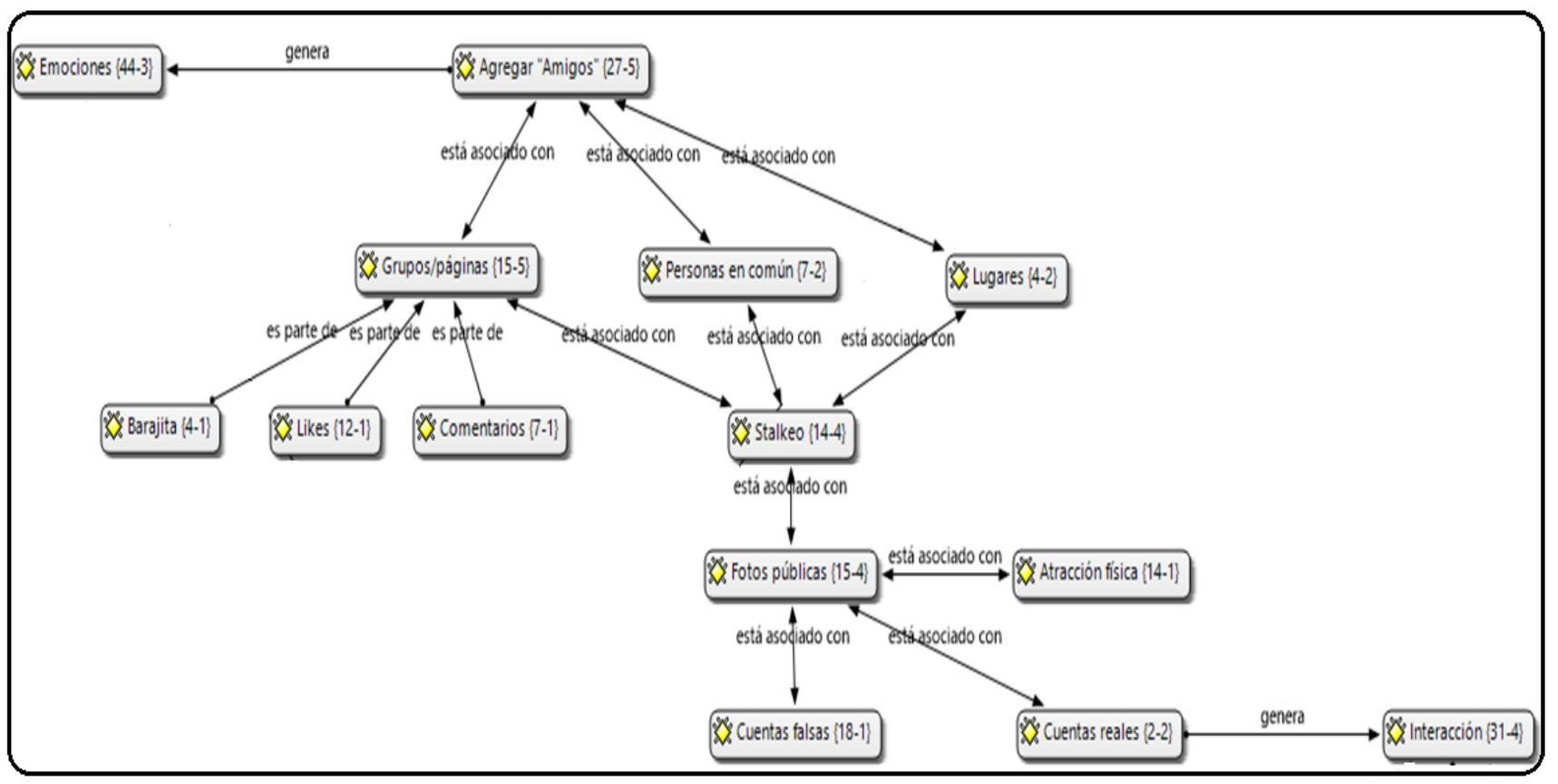

Figura 9. Mapa de Redes "Segunda parte: Formas de agregar amigos"

Para Agregar "Amigos", existen tres formas: por medio de los grupos/páginas, personas en común y/o lugares, los cuales cuentan con dinámicas que ayudan en la primera interacción, a través del papel de las fotos públicas, los likes y los comentarios para dar paso al stalkeo como medio para evaluar los perfiles de los demás usuarios y considerar enviar o aceptar la solicitud de amistad, ya que los participantes comprenden que se encuentran en un contexto social donde la inseguridad está a la orden del día, por lo que, toman sus precauciones; aunque esta evaluación de perfiles (en específico las fotografías) no solo está enfocada en la seguridad sino también en agregar a personas que se consideran están dentro de los estándares de belleza (en el caso de los hombres), es decir, la atracción física por medio de las fotos se hace frecuente, y esto motiva a enviar solicitudes de amistad para después comenzar con la conversación. Entonces, el stalkeo es una forma de seguridad y un medio para agregar personas. 


\section{4) INTERACCIÓN}

Gustos

Cuando se constata que se trata de la persona que dice ser, se acepta o se envía la solicitud de amistad, dando comienzo a la interacción, inicialmente como una presentación de ambas personas involucradas, conocerse de manera más íntima a través de la comunicación privada (llamadas y/o mensajes), aspectos como los gustos y su género de música favorita son los temas más recurrentes:

\begin{tabular}{|c|c|}
\hline Participante 2, Mujer & “(...) Veo que publicas tales canciones, ¿qué música te gusta?”...” \\
\hline Participante 4, Mujer & "(...) platicábamos de música, porque como que los dos éramos muy afines...” \\
\hline Participante 5, Mujer & $\begin{array}{l}\text { "(...) eran llamadas de una hora o } 2 \text { horas donde hablábamos mucho (...) de los } \\
\text { gustos y lo de la música..." }\end{array}$ \\
\hline Participante 3, Hombre & “(...) había confiado tanto en mí, me contaba todos sus gustos (...)” \\
\hline
\end{tabular}

De acuerdo con Finkel, et al. (2014), las relaciones de pareja en nuestra actualidad consisten en la exploración mutua teniendo como fin la autorealización y felicidad; y el amor surge a partir de conocer al otro. Para los entrevistados "hablar diario" es la oportunidad de saber de la vida cotidiana del otro (dónde vive, quién es su familia, qué hace en la escuela o en el trabajo, etc.), y aquellos que mantenían una conversación con personas de otro país, preguntaban sobre su cultura, sus costumbres y los lugares para visitar; así que la comunicación genera un ámbito de intimidad:

\begin{tabular}{|c|c|}
\hline Participante 1, Mujer & $\begin{array}{l}\text { “(...) primero, era más interacción por la página, y después ya de “hola, ¿cómo } \\
\text { estás?, ¿qué haces?”, (...) empezamos a platicar de un tema, nos pasamos a } \\
\text { otro,(...) contando nuestras vivencias, de nuestras relaciones pasadas, amistades, } \\
\text { tecnología, como que eran temas muy variados, pero siempre era por inbox..."” }\end{array}$ \\
\hline Participante 2, Mujer & $\begin{array}{l}\text { “(...) él me dijo "Hola, ¿cómo estás? (...) yo a interactuar con una persona que } \\
\text { me llame la atención pues sería mucho el estar platicando, pues con un "hola, } \\
\text { ¿cómo estás?” a lo mejor durante todo el día, a lo mejor una vez al día...", }\end{array}$ \\
\hline Participante 3, Mujer & $\begin{array}{l}\text { “(...) sí empezamos a platicar "ah, yo soy de acá” "no, pues yo soy acá” "Pues } \\
\text { acá, puedes visitar tal lado” y ya empezamos a decirnos “yo trabajo de esto, no } \\
\text { pues yo de esto” y el clásico ¿no?, “yo estoy con mi esposa pero no me llevo bien } \\
\text { con ella, tengo } 2 \text { hijos” o sea conocí todo de su vida igual yo le platique que yo }\end{array}$ \\
\hline
\end{tabular}




\begin{tabular}{|c|c|}
\hline & $\begin{array}{l}\text { era soltera pero tenía una hija y hasta que un día comenzamos a comunicarnos, } \\
\text { me hablaba por teléfono por WhatsApp..." }\end{array}$ \\
\hline Participante 4, Mujer & $\begin{array}{l}\text { “(...) empezamos a hacer la plática, fue como una plática de } 4 \text { horas seguidas, y } \\
\text { pues ahí empezó como que el afecto, porque nos empezamos a hablar todos los } \\
\text { días, todo el día, entonces, me empecé a acostumbrar a hablar con él y él conmigo } \\
\text { y empezó como que ese cariño de amigos (...) platicábamos (...) de las cosas que } \\
\text { nos pasaban en el día a día, o de nuestras familias (...) de las cosas que nos } \\
\text { hacían gracia...” }\end{array}$ \\
\hline Participante 5, Mujer & $\begin{array}{l}\text { “(...) fue que empezamos a hablar más, como alguien que nos gusta y ahí fue } \\
\text { cuando inició con las llamadas, (...) eran llamadas de una hora o } 2 \text { horas donde } \\
\text { hablábamos mucho, de su trabajo, de nuestra familia también de qué hacía su } \\
\text { familia, los amigos que tenía, mis amigos, la prepa, yo la escuela, él el trabajo, } \\
\text { de qué es lo que queríamos hacer al día siguiente y “¿qué vas a hacer } \\
\text { mañana?”..." }\end{array}$ \\
\hline Participante 6, Mujer & $\begin{array}{l}\text { "(...) le pregunté de qué turno era y así, pues hablamos de cómo nos iba en la } \\
\text { escuela o de dónde vivíamos..." }\end{array}$ \\
\hline Participante 1, Hombre & $\begin{array}{l}\text { "(...) hubo una conexión tan perfecta que nos llevamos muy bien yo y ella, nos } \\
\text { hacíamos videollamadas, (...)" }\end{array}$ \\
\hline Participante 2, Hombre & $\begin{array}{l}\text { “(...) “ ¿de dónde eres?” “ah, pues de un pueblito de aquí de Buenos Aires que } \\
\text { se llama tal” "yo pues soy de la Ciudad de México de la capital de México” "ah, } \\
\text { qué buena onda, a mí me gusta mucho México (...) entonces, empezó de ahí la } \\
\text { conexión con ella "Ah, pues cuando quieras ven yo soy tu guía de turistas”..." }\end{array}$ \\
\hline Participante 3 , Hombre & $\begin{array}{l}\text { "(...), y después de eso ya era diario, y fíjate yo veía que si la plática iba muy } \\
\text { bien nos quedamos hasta las } 3 \text { de la mañana, siempre empezábamos a platicar } \\
\text { tantas cosas que yo sé que sacaban todo conmigo y pues nos complementaba y } \\
\text { platicábamos y estaba muy entretenido y duraba tanto la plática que el otro día } \\
\text { otra vez, ya era diario, pero después de las 3:00 de la mañana ya, sabía que se } \\
\text { había armado todo (...) o sea me confiaban totalmente todo que empezábamos a } \\
\text { llevarnos tan bien..." }\end{array}$ \\
\hline Participante 4, Hombre & $\begin{array}{l}\text { “(...) bueno ahí estuvimos hablando era del diario con esa incógnita de ¿cómo } \\
\text { será? (...) ya empezó el proceso de hablar diario con ella, "Hola, ¿cómo estás?” } \\
\text { (...) entonces, empezamos a platicar de su vida o sea empiezas esa relación de } \\
\text { ¿qué haces?” o “qué tal el día?” diario, y “ ¿a qué te dedicas?” y todas esas } \\
\text { cosas como cualquier persona...” }\end{array}$ \\
\hline
\end{tabular}




\section{Confianza}

Saber del otro como a qué se dedican, incluso cuestiones familiares y gustos se expresan, lo que genera confianza, pues según Esteinou, (2017), para realmente conocer y entender una persona se requiere de una interacción intensa donde se presentan privilegios, es decir, no todos acceden a esa información:

\begin{tabular}{|c|l|}
\hline Participante 1, Mujer & $\begin{array}{l}\text { “...) no se nos acaba el tema de conversación, nos tenemos confianza, (...) } \\
\text { primero nos hicimos muy amigos (...) y empezamos así a conocernos, tenemos } \\
\text { cosas en común y bueno, de repente fue que tenemos esa confianza....” }\end{array}$ \\
\hline Participante 6, Mujer & $\begin{array}{l}\text { "...) él siempre fue muy respetuoso conmigo siempre intentaba ayudarme o sea } \\
\text { si le que tenía un problema siempre intentaba escucharme o apoyarme por } \\
\text { eso creo que le tuve mucha confianza...” }\end{array}$ \\
\hline Participante 3, Hombre & \begin{tabular}{l} 
lograba que confiaran tan rápido en mí....” confiaban totalmente todo que empezábamos a llevarnos tan bien que \\
\hline
\end{tabular}
\end{tabular}

Diferencias (entre hombres y mujeres)

Cabe señalar que se indicó que los hombres dentro de la interacción de conocer a las chicas, ellos tomaban el rol de escucha, pues ellas manifestaban sus problemas:

\begin{tabular}{|c|l|}
\hline Participante 6, Mujer & $\begin{array}{c}\text { “...) si le decía que tenía un problema siempre intentaba escucharme o } \\
\text { apoyarme...” }\end{array}$ \\
\hline Participante 1, Hombre & “(..) de hecho esa muchacha me contó sus problemas...” \\
\hline Participante 3, Hombre & “(...) había confiado tanto en mí, me contaba todo, todos sus problemas...” \\
\hline
\end{tabular}

La intimidad es un conocimiento y una comprensión profunda (Esteinou, 2017), la cual después genera una conexión emocional, así que contar los problemas es considerado una forma de relacionarse más estrechamente, llegando a crear un trato familiar y comprensivo.

\section{Coqueteo y Ligue (flirtear)}

Esto da paso al siguiente elemento: el coqueteo; frases como "me tira la onda" comienzan a tener sentido pues después de haber hablado de manera constante logran conocerse. Comentarios como “estás bonita”, “me gusta cómo eres” “¿soy tu tipo?” y “no 
tengas novio" son frases que ayudan al entendimiento del próximo ligue, señales de interés que se fortalecen con la plática "me gusta cómo eres"; el mundo de significado va orientado a conversar constantemente y hacer ese tipo de comentarios generan una atmosfera de coqueteo y de interés por el otro; de acuerdo con Mead (1973) por medio de la sociabilidad entendemos los gestos de los demás, se adopta el papel del otro (el Mî́) para crear símbolos significantes, en este caso, estas expresiones escritas el otro las entiende como "indicadores" de que se pretende otro tipo de relación afectiva (a esto se le conoce como flirtear):

\begin{tabular}{|c|c|}
\hline Participante 1, Mujer & $\begin{array}{l}\text { "(...) platicábamos casi todo el día y habíamos creado una amistad, que ya } \\
\text { sabíamos que nos gustábamos (...) "no, pues es que quiero conocerte, verte en } \\
\text { persona” (...) fue cuando dijo "espérame, no tengas novio, quiero conocerte } \\
\text { como algo más y me gusta tu forma de ser" "pues a mí también me gusta tu forma } \\
\text { de ser" y dije sería "interesante conocerte”...." }\end{array}$ \\
\hline Participante 2, Mujer & $\begin{array}{l}\text { “(..) nos estábamos escribiendo a lo mejor durante todo el día, de lo que fuera } \\
\text { ¿no? hasta cosas ya más personales "oye me gustas, me gusta como piensas, me } \\
\text { llamas la atención”...” }\end{array}$ \\
\hline Participante 5, Mujer & $\begin{array}{l}\text { “(...) ya éramos amigos, ya nos hablábamos de todo y ya fue que me empezó a } \\
\text { decir "¿qué opinaba de una relación a distancia? Que si creía que estaba bien, } \\
\text { ¿si podríamos llegar a tener una relación así? Y yo le dije "pues nunca he } \\
\text { experimentado eso pero yo creo que sí...” }\end{array}$ \\
\hline Participante 2, Hombre & $\begin{array}{l}\text { "(...) empezamos a hablar así en privado (...) me tiraba la onda, me dijo que "si } \\
\text { era su tipo” (...) "no, pues sí eres mi tipo” (...) pero sí, era demasiado evidente } \\
\text { que ella quería algo porque me mandaba fotos y me decía “ ¿soy tu tipo o no soy } \\
\text { tu tipo?” era muy evidente ¿no?...” }\end{array}$ \\
\hline Participante 3 , Hombre & $\begin{array}{l}\text { "(...) nunca me aventaba totalmente íbamos por partes digo, los "me gusta”, las } \\
\text { pláticas, los primeros mensajes, (...) le decía "ah, en esta foto te ves muy bonita" } \\
\text { y decía "no, cómo crees", (...) me decía "ay, a poco si te gusta" y le digo "sí, me } \\
\text { gusta tu foto" y a como que se veía que íbamos a andar o sea como que nunca fue } \\
\text { al aventón..." }\end{array}$ \\
\hline
\end{tabular}

\section{Diferencias (entre hombres y mujeres)}

Como acabamos de ver en el cuadro anterior, se construye una atmosfera en la cual se crean los sobreentendidos (Hofstatter, 1966), ¿cómo sé que la otra persona también le gustamos?, Para los participantes es la constancia en la comunicación, saber uno del otro y 
decir halagos o directamente exponer su gusto por la otra persona, son señales de interés. Por otro lado, se presenta cómo solo una mujer es quién realiza los primeros comentarios para resaltar el interés que tiene por la otra persona; mientras que los hombres por lo regular son quienes realizan ese tipo de comentarios y las mujeres reciben esas "indirectas". La coquetería para Simmel (citado en Gómez, 2006) es una situación fluida (un va y viene), donde la mujer aprueba lo que se hace o se dice, seleccionando así su próximo ligue (la posibilidad de comenzar una relación de pareja), en otras palabras, es ella quién permite que se dé y se desarrolle este ámbito llamado coqueteo, porque acepta y/o continúa lo dicho por el hombre.

A continuación se muestran otros fragmentos de las entrevistas que ilustran la reciprocidad de los comentarios o acciones que hacen posible el coqueteo:

\begin{tabular}{|c|l|}
\hline \multirow{5}{*}{ Participante 1, Mujer } & $\begin{array}{l}\text { (...) le había dejado claro de que no estaba buscando nada con nadie, como que } \\
\text { él se daba cuenta de que a mí sí me interesaba, ya lo intuía, ya lo sabía pero no } \\
\text { se animaba a decirlo, (...) fue de forma indirecta le dije que no me interesaba } \\
\text { nadie más que él...” }\end{array}$ \\
\hline Participante 3, Hombre & $\begin{array}{l}\text { (...) yo le empezaba a decir (...) “hola, que tengas un excelente día” y ella me } \\
\text { responde “ah, muchas gracias, tú también ten un excelente día” y así como que } \\
\text { creaba la expectativa de que nos gustábamos..., }\end{array}$ \\
\hline
\end{tabular}

En seguida, se presenta la tercera parte del Mapa de Redes en donde se hace referencia a la relación entre los códigos Interacción, Gustos, Confianza, Coqueteo, Ligue/Flirteo e Inicio del noviazgo:

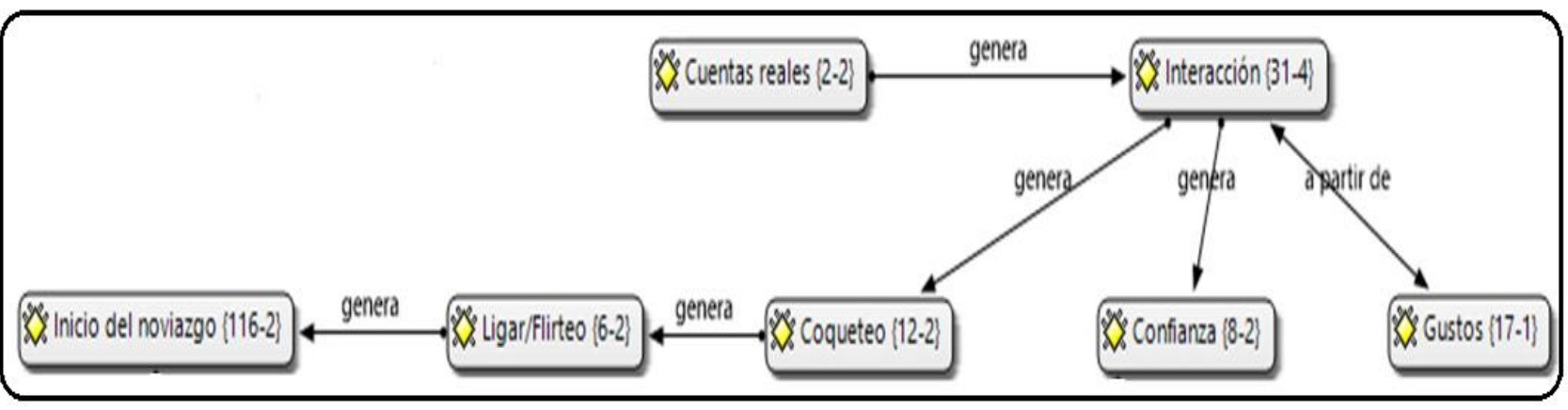

Figura 10. Mapa de Redes "Tercera parte: Primera interacción al inicio de la relación”

Después de constatar que se trata de una cuenta "real" (es la persona que dice ser), los usuarios se agregan para continuar con la interacción, en este caso, las primeras 
conversaciones están relacionadas con conocer al otro a partir de sus gustos, sus problemas o cuestiones cotidianas de lo que sucede en la escuela o en el trabajo; hablar "diario" contribuye a la construcción de la confianza y el coqueteo, indirectas y/o halagos que se vuelven indicadores para dar comienzo al ligue, dando paso a la transformación de la relación amistosa a una de noviazgo.

\section{5) INICIO DEL NOVIAZGO}

Después de mantener por varios días e incluso meses la primera interacción, y se crea el ambiente del coqueteo, se da paso a exponer la frase “¿quieres ser mi novia/novio?”, siendo un elemento normado para el inicio del noviazgo donde toma otro sentido la interacción. El lenguaje construye realidades (Fernández, 2004), por ejemplo, frases como "hay que andar" "me gustaría que fueras mi novia” "¿quieres ser mi novia/novio? Generan otras pautas de acción, cambiando la dinámica dentro de la pareja que comenzaba a conocerse:

\begin{tabular}{|c|c|}
\hline Participante 1, Mujer & 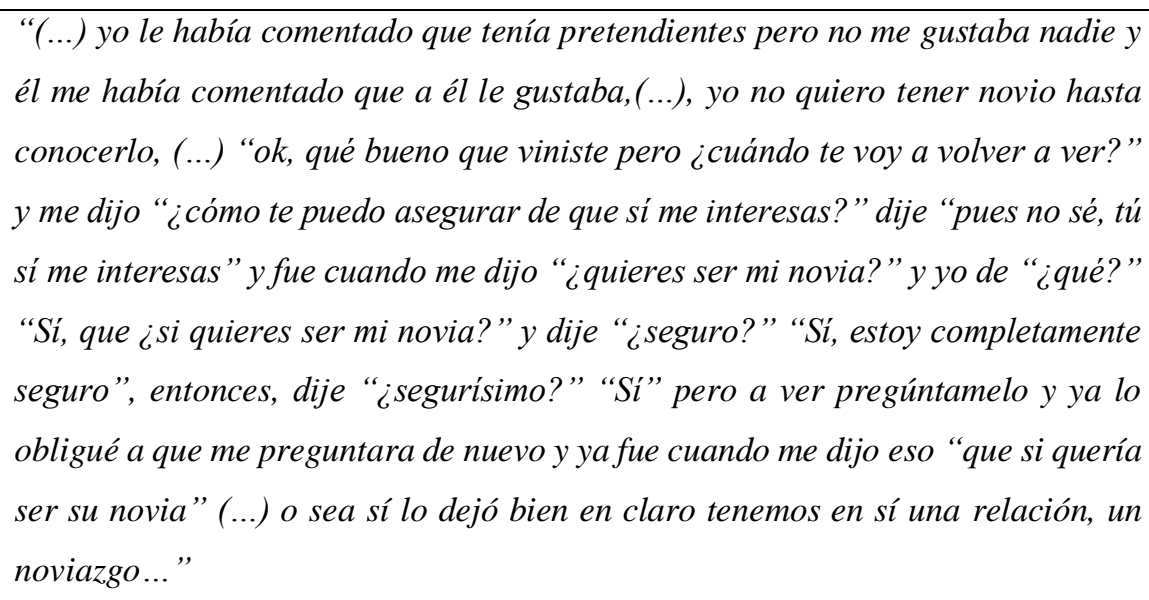 \\
\hline Participante 2, Mujer & $\begin{array}{l}\text { “(...) creo que fue él quien me dijo “ ¿quisieras tener una relación de novios } \\
\text { conmigo? Y yo ¿por qué no?, pues todo el tiempo me la pasaba ahíy dije "bueno”, } \\
\text { entonces, así fue como se fue desarrollando la relación, de hecho él fue quién me } \\
\text { lo dijo, pero fue más por la interacción diaria que teníamos...” }\end{array}$ \\
\hline Participante 3, Mujer & $\begin{array}{l}\text { "(...) comenzamos a comunicarnos, me hablaba por teléfono por WhatsApp y ahí } \\
\text { fue cuando empezó "oye, me gustaría que fueras mi novia” y yo le dije "pero tan } \\
\text { lejos, ni nos vamos a ver ni nada" luego ya nos haciamos vídeollamadas..." }\end{array}$ \\
\hline Participante 4, Mujer & $\begin{array}{l}\text { "(...) estábamos platicando y fue como "oye, pues es que me gustas y siento que } \\
\text { te amo" y yo "pues sí, tú también me gustas, siento algo muy fuerte por ti, aunque } \\
\text { no te tenga cerca" y me dijo "pues, hay que intentarlo" y yo "pues bueno" como }\end{array}$ \\
\hline
\end{tabular}




\begin{tabular}{|c|c|}
\hline & $\begin{array}{l}\text { que lo dude un poquito, porque dije "híjole, es que está muy lejos" pero pues ya } \\
\text { después le dije "órale ¡va!, hay que intentarlo" y pues así sucedió..." }\end{array}$ \\
\hline Participante 5, Mujer & $\begin{array}{l}\text { “(...) yo le di mi celular y en eso me marcó por teléfono de mi mamá y ya fue que } \\
\text { me dijo "que si quería ser su novia” y ya le dije que "si”...", }\end{array}$ \\
\hline Participante 6, Mujer & $\begin{array}{l}\text { “(...) empezamos a salir un poco más porque nos veíamos más en la escuela y } \\
\text { porque me invitaba cuando tocaba en el bar, yo siempre iba a verlo, empezamos } \\
\text { a convivir más, solo empezamos a salir más y ya se dio...” }\end{array}$ \\
\hline Participante 1, Hombre & $\begin{array}{l}\text { “(...) Yo tome el primer paso (...) le dije que "si quería ser mi novia” (...) y me } \\
\text { dijo que sí...” }\end{array}$ \\
\hline Participante 2, Hombre & $\begin{array}{l}\text { "(...) se lo dije así "pues vamos a ser novios, vamos a tener una relación”" pero } \\
\text { sí ella era demasiado evidente que a ella quería algo (...) entonces, le dije "ah, } \\
\text { pues vamos a ser novios, vamos a andar" “no, pues sí, sí quiero ser tu chica”...”, }\end{array}$ \\
\hline Participante 3 , Hombre & $\begin{array}{l}\text { “(...) me gustaba y decirle “ah, pues nos llevamos muy bien podemos empezar a } \\
\text { andar ¿quieres ser mi novia?” y luego se lo decia hasta por Facebook, no siempre } \\
\text { era en vivo...” }\end{array}$ \\
\hline Participante 4, Hombre & $\begin{array}{l}\text { “(..) decirle “¿sabes qué? Me gustas mucho, ¿qué onda?” (...) se lo dije por } \\
\text { teléfono (...) y te digo estuvimos hablando hasta que dije “ ¿sabes qué?, ¿quieres } \\
\text { ser mi novia?” y ella aceptó...”, }\end{array}$ \\
\hline
\end{tabular}

\section{Diferencias (entre hombres y mujeres)}

Respecto a lo expuesto en el cuadro anterior, notamos que los hombres fueron quienes definieron la relación, partiendo de las palabras “¿quieres ser mi novia?”, y las mujeres aceptaron iniciar el noviazgo (figura 11, Anexo 6); y aunque parezca que toma un papel pasivo, hay que entender que ambos crean la atmósfera del coqueteo, así que el hombre no procede a preguntar si ella no da "indicadores" de que siente lo mismo, por lo tanto, ambos géneros interpretan acciones (a partir de comentarios o indirectas) así después el hombre procede a preguntar: ¿quieres ser mi novia? Y la mujer es quien decide el comienzo o no de la relación. Para este punto, se presentan los Sobreentendidos (Hofstatter, 1966), pues ¿cómo sé que es el hombre quién "debe" dar el primer paso? Bueno, estamos inmersos en un contexto sociocultural en el cual la idea del amor y la pareja está regida por acciones dependiendo del género, así que de acuerdo con las pautas tradicionales (históricamente a partir de los aspectos laborales y religiosos (Finkel et. al. 2014; Estébanez, 2015), son los hombres quienes toman la iniciativa. 
De acuerdo con lo señalado anteriormente, el lenguaje (Fernández, 2004) crea realidades, y después de expresar la frase “¿quieres ser mi novia?” surgen nuevas pautas de acción, como dirigirse a la otra persona de "mi amor", etiquetando la forma de definirse mutuamente, transformando así la relación de amistad a una de pareja:

\begin{tabular}{|c|l|}
\hline Participante 4, Mujer & $\begin{array}{l}\text { "(...) seguíamos con las pláticas como si fuéramos amigos, pero le agregábamos } \\
\text { el sufijo de mi amor, mi vida, te amo, pero seguíamos platicando del día a día, de } \\
\text { las cosas que nos hacían gracia, y le platicaba de lo que a mí me pasaba en la } \\
\text { universidad y él me platicaba lo que le pasaba en la escuela..." }\end{array}$ \\
\hline Participante 5, Mujer & $\begin{array}{l}\text { "(...) hablábamos igual, era casi lo mismo pero ya era con nuestros apodos de } \\
\text { "mi amor", "mi cielo” yo creo que al principio si fue normal dentro de lo que } \\
\text { cabe igual a excepción de que ya era éramos novios pero después empezamos a } \\
\text { querer saber más de nosotros..." }\end{array}$ \\
\hline
\end{tabular}

\section{6) MANTENIMIENTO DEL NOVIAZGO}

Las palabras entendidas, para estos sujetos de estudio, como románticas aparecen, y esto es a través de expresiones de "te quiero", "te amo"; estos términos se llevan a cabo a partir de una vía: compartir información de manera pública, es decir, exponer su cariño a través de imágenes, fotos o vídeos con sentido para ellos (porque la canción habla de su situación amorosa, porque se identifican con la imagen, etc.), acompañados de texto como "mira mi amor" y emoticones (corazones), a esto se le conoce como símbolos significantes (Mead, 1973), pues en las conversaciones surgen estos signos que son entendidos por la pareja y el resto de los usuarios, donde se asocia la imagen de un corazón con la idea del amor romántico, por lo tanto, las personas lo utilizan para expresar este sentimiento y dar a conocer su relación a través de este medio virtual:

\begin{tabular}{|c|c|}
\hline Participante 2, Mujer & $\begin{array}{l}\text { "(...) cuando ya teníamos esa relación, usualmente nos dedicábamos canciones, } \\
\text { yo publicaba una canción a lo mejor en su muro en Facebook, y ya lo comentaba } \\
\text { y era de "yo te amo más", "yo más" y emoticones y corazones o igual él hacía } \\
\text { publicaciones de algún vídeo musical, siempre nos demostrábamos ese cariño, } \\
\text { ese amor por medio de la música, pues "ahora te dedico esta canción”, o igual } \\
\text { en las imágenes así bonitas románticas..." }\end{array}$ \\
\hline Participante 6, Mujer & $\begin{array}{l}\text { "(...) subiamos fotos juntos de que salíamos y en la descripción poníamos "te } \\
\text { quiero mucho y corazoncitos"..." }\end{array}$ \\
\hline
\end{tabular}




\section{Información Pública y Privada}

Ahora que se presentan muestras de afecto a partir de las publicaciones ¿todos los entrevistados hacen pública su relación? De acuerdo con lo narrado en las entrevistas (10 casos), 6 de los participantes compartían información sobre su relación en su perfil de Facebook, es decir, la expresaban públicamente por medio de imágenes, comentarios o fotos juntos (figura 12, Anexo 6). Para Rodríguez y Rodríguez, (2016), el objetivo de las fotos o la información compartida como pareja es la búsqueda de reconocimiento, de mostrar que se sienten bien y expresar orgullo de que se encuentran juntos.

\section{Diferencias (entre hombres y mujeres)}

Para entrar más en detalle sobre el número de participantes que exponen su relación de manera pública, a continuación, se presentan los fragmentos que nos ayudan a visualizar como la mitad del total de hombres ( 2 de 4 casos) y más de la mistad de mujeres (4 de 6 casos) hacen pública su relación (figura 13, Anexo 6). Además, el contenido de estas publicaciones se basa en las fotos, en los poemas, en las canciones o escribir su sentir por la otra persona:

\begin{tabular}{|c|c|}
\hline Participante 1, Mujer & $\begin{array}{l}\text { "(...) el primer día, nos empezamos a tomar fotos, y él puso la de perfil de } \\
\text { nosotros en la que salimos juntos (...) cuando él me dijo que iba a venirse para } \\
\text { acá, yo hice una publicación en la página de la Isla Benshortiana, porque él decía } \\
\text { que iba a venir un vecino jarocho a conocerme..." }\end{array}$ \\
\hline Participante 2, Mujer & $\begin{array}{l}\text { “(...) usualmente nos dedicábamos canciones, yo publicaba una canción a lo } \\
\text { mejor en su muro en Facebook, y ya lo comentaba y era de "yo te amo más", "yo } \\
\text { más" y emoticones y corazones, siempre nos demostrábamos ese cariño, ese amor } \\
\text { por medio de la música, pues "ahora te dedico esta canción”, o igual en las } \\
\text { imágenes así bonitas románticas..." }\end{array}$ \\
\hline Participante 5, Mujer & $\begin{array}{l}\text { "(...) siempre he sido más de subir una foto y ahora que están las historias } \\
\text { siempre trato de vez en cuando subir una foto de yo y él, poner una canción nueva } \\
\text { para dedicar (...) en ese tiempo los dos éramos muy detallistas en esos aspectos, } \\
\text { teníamos un momento de poemas y él me escribía poemas..." }\end{array}$ \\
\hline Participante 6, Mujer & $\begin{array}{l}\text { "(...) Sí, pues sí publicamos fotos, pues sí cuando hacíamos algo o salimos a } \\
\text { algún lugar subimos fotos, sí...” }\end{array}$ \\
\hline
\end{tabular}




\begin{tabular}{|c|c|}
\hline Participante 1, Hombre & $\begin{array}{l}\text { "(...) Ella me compartía estados románticos de "hola, te amo mi amor, gracias } \\
\text { por estar" asi ese tipo de estados y yo siempre le comentaba "yo también te } \\
\text { amo..." }\end{array}$ \\
\hline Participante 3 , Hombre & $\begin{array}{l}\text { "(...) Por Facebook yo siempre he puesto la relación... tengo la maña de enviar } \\
\text { la relación o sea "(su nombre) ha cambiado de soltero a tener una relación con } \\
\text { tal persona” siempre me he considerado que he sido una persona muy } \\
\text { romántica..." }\end{array}$ \\
\hline
\end{tabular}

Por otro lado, se dan los casos en los cuales los participantes señalaron no escribir mensajes públicos, solo enviarse información entre ellos como pareja, con la finalidad de mantenerse en contacto y como forma de saber que el otro está ahí (que la relación continua):

\begin{tabular}{|c|c|}
\hline Participante 3, Mujer & $\begin{array}{l}\text { “(...) No, así que pusiera “ay, estoy muy feliz y muy contenta tengo un novio de } \\
\text { Ecuador” No, eso quedo entre nosotros así, ni en la página en la que estábamos, } \\
\text { no, jamás lo expresamos...” }\end{array}$ \\
\hline Participante 4, Mujer & $\begin{array}{l}\text { "(...) cuando nos hicimos pareja, no éramos como de publicarnos en el muro de } \\
\text { Face, nos decíamos todo por mensaje..." }\end{array}$ \\
\hline Participante 2, Hombre & $\begin{array}{l}\text { "(...) me empezó a decir que "no, que Facebook es una porquería, no me } \\
\text { agregues"..." }\end{array}$ \\
\hline Participante 4 , Hombre & $\begin{array}{l}\text { “(...) teníamos un grupo (privado), hicimos un grupo y subimos fotos y "buenos } \\
\text { días, espero te vaya bien” cosas que hicieran que la relación se impulsará, } \\
\text { expresábamos lo que sentíamos, lo que queríamos que sintiera la otra persona y } \\
\text { que le fuera bien, era del diario "buenos días"..." }\end{array}$ \\
\hline
\end{tabular}

Vinculación con otras Redes (WhatsApp)

La integración del WhatsApp, se vuelve elemental y complementaria, pues se recurre a Facebook y a él para conversar: el primero para conocerse y el segundo para intercambiar información privada a partir de mensajes ligada a los recursos visuales (fotos, textos y vídeos). Asimismo, la construcción de la confianza, proporciona la oportunidad de compartir el número telefónico personal:

Participante 1, Mujer

“(...) todos los audios son por Whatsapp, incluso las video llamadas (...) creo que hicimos como una separación, para memes y publicaciones tenemos 


\begin{tabular}{|c|l|}
\hline & $\begin{array}{l}\text { Facebook, pero más para comunicación, hablarnos, audios, son para } \\
\text { Whatsapp...” }\end{array}$ \\
\hline Participante 2, Mujer & $\begin{array}{l}\text { “(..) se fue prestando la situación en que yo le diera esa confianza de pasarle el } \\
\text { número de teléfono.... }\end{array}$ \\
\hline Participante 3, Mujer & “(...) ya empezó a ser así por WhatsApp, no por Facebook...” \\
\hline Participante 4, Mujer & $\begin{array}{l}\text { “(...) me empezó a hablar por Whats, y yo le dije “me parece más cómodo hablar } \\
\text { por Whats que por Face”.... }\end{array}$ \\
\hline Participante 5, Mujer & “(...) hay más posibilidad de hablamos porque ya está el WhatsApp...” \\
\hline Participante 2, Hombre & “(...) Por Whats nos hablábamos y por el Face...” \\
\hline
\end{tabular}

\section{Diferencias (entre hombres y mujeres)}

Con relación al uso de otras formas de comunicación acompañando los textos y las imágenes; ahora los usuarios disponen y hacen uso de otros medios como las llamadas, las vídeollamadas y los audios. Para los participantes, son los hombres quienes utilizan más las vías de comunicación privadas, en las cuales solo los involucrados tienen acceso a esa información (figura 14, Anexo 6).

En seguida se muestran los fragmentos que ilustran lo expuesto en el párrafo anterior:

\begin{tabular}{|c|c|}
\hline Participante 1, Mujer & $\begin{array}{l}\text { "(...) él siempre esta como comunicándose, hasta cuándo va con su familia, o me } \\
\text { graba audios de lo que hace..." }\end{array}$ \\
\hline Participante 2, Mujer & $\begin{array}{l}\text { "(...) diario me mandaba un mensaje "Hola, buenos dias, bonita” "te quiero } \\
\text { mucho"..." }\end{array}$ \\
\hline Participante 3, Mujer & $\begin{array}{l}\text { “(...) me dijo "¿qué te parece si hacemos una vídeo llamada? Así más o menos } \\
\text { te veo” y le digo "Bueno, márcame” (...) él me marcaba por lo regular en las } \\
\text { mañanas..." }\end{array}$ \\
\hline Participante 4, Mujer & $\begin{array}{l}\text { “(...) éramos más por mensaje, nos decíamos todo por mensaje y yo tenía la } \\
\text { contraseña de su Facebook y él tenía la contraseña de mi Facebook, entonces } \\
\text { cuando él me quería publicar algo se metía desde mi Facebook y escribía una } \\
\text { publicación, pero la ponía en privado para que solo yo la viera, entonces, así era } \\
\text { la forma en la que nos publicábamos...” }\end{array}$ \\
\hline Participante 5, Mujer & $\begin{array}{l}\text { “(...) para esas fechas ya me marcaba por teléfono, pero le marcaba al teléfono } \\
\text { de mi mamá y él tampoco no ganaba mucho pero me decía “ ¿te puedo hacer una } \\
\text { llamada? Al mes de una hora o dos horas para aprovechar”...” }\end{array}$ \\
\hline
\end{tabular}




\begin{tabular}{|l|l|}
\hline Participante 2, Hombre & $\begin{array}{l}\text { “(...) Tengo el cable con llamadas ilimitadas, ya puedo estar ahí todo el día } \\
\text { hablándole y no me cobran más, hacíamos llamadas videollamadas también por } \\
\text { el Whats todo mensajes...” }\end{array}$ \\
\hline Participante 3, Hombre & "(...) les enviaba de "buenos días”, así con imágenes o les tomaba foto...”" \\
\hline Participante 4, Hombre & $\begin{array}{l}\text { "(...) en ese tiempo no había esta cuestión de contratar internet, entonces, yo al } \\
\text { mes tenía mi límite de tiempo de hablar con ella una hora al mes o sea a } 60 \\
\text { minutos por teléfono y lo demás fue por internet...” }\end{array}$ \\
\hline
\end{tabular}

Los mensajes juegan un papel relevante en la relación, pues con ellos siguen conociéndose el uno al otro, se presenta el sexting, los packs, los audios, las llamadas, las vídeollamadas, los vídeos etc.; en otras palabras, a través de estos medios privados, los participantes comunican aspectos más personales y sexuales; así como los conflictos y las rupturas como pareja. De acuerdo Bernal et al. (2015), estamos en la búsqueda de la exhibición y reconocimiento, las relaciones de pareja que se expresan a través de Facebook serán blanco de críticas, por lo que, a través de las publicaciones se trata de mostrar un tipo de amor ideal, donde los conflictos y las cuestiones íntimas se discuten a través de mensajes privados, donde nadie más que ellos pueden saberlos:

\begin{tabular}{|c|c|}
\hline Participante 3, Mujer & $\begin{array}{l}\text { "(...) Fue por WhatsApp porque ya no quise hablar con él, entonces, le mandé un } \\
\text { WhatsApp en donde le dije "ya no quiero nada contigo, y él me dijo "pero ¿por } \\
\text { qué? Si estábamos tan bien”, "no, la verdad es que esto no lo veo para ningún } \\
\text { lado”..." }\end{array}$ \\
\hline Participante 5, Mujer & $\begin{array}{l}\text { "(...) él grababa cuando nos mirábamos por webcam donde yo me acercaba asî } \\
\text { como si me fuera a dar un beso y él grababa un vídeo, entonces, esos videos los } \\
\text { subí a ese grupo (privado)..." }\end{array}$ \\
\hline Participante 2, Hombre & $\begin{array}{l}\text { “(...) teníamos nuestros momentos cachondos, sexuales lo que sea, mandarnos } \\
\text { fotos, vídeos, audios, de todo pero ya así sexual ¿no? con la otra también tuvo } \\
\text { cosillas sexuales pero no tanto...” }\end{array}$ \\
\hline Participante 3 , Hombre & $\begin{array}{l}\text { "(...) utilice el Facebook para terminar, le mandé un mensaje por Facebook de } \\
\text { hecho nunca las terminé en vivo (...) les mande un mensaje que era muy } \\
\text { depresivo..." }\end{array}$ \\
\hline
\end{tabular}


La vida pública y la vida privada aquí se manifiestan, por un lado, las publicaciones acompañadas de vídeos, imágenes, canciones y con frases de "te quiero" generan la presentación de la pareja. Pero no se expresan en las publicaciones en el muro cuestiones como problemas entre la pareja o situaciones sexuales, por lo tanto, hay una división y un criterio de ¿qué se publica y qué no? Habrá cuestiones que solo se quedan para ellos y otras serán mostradas al público, a sus seguidores y amigos. A continuación, se presenta la cuarta parte del mapa, el cual visualiza las conexiones entre los códigos mencionados en los apartados "Inicio del noviazgo" y "Mantenimiento del Noviazgo":

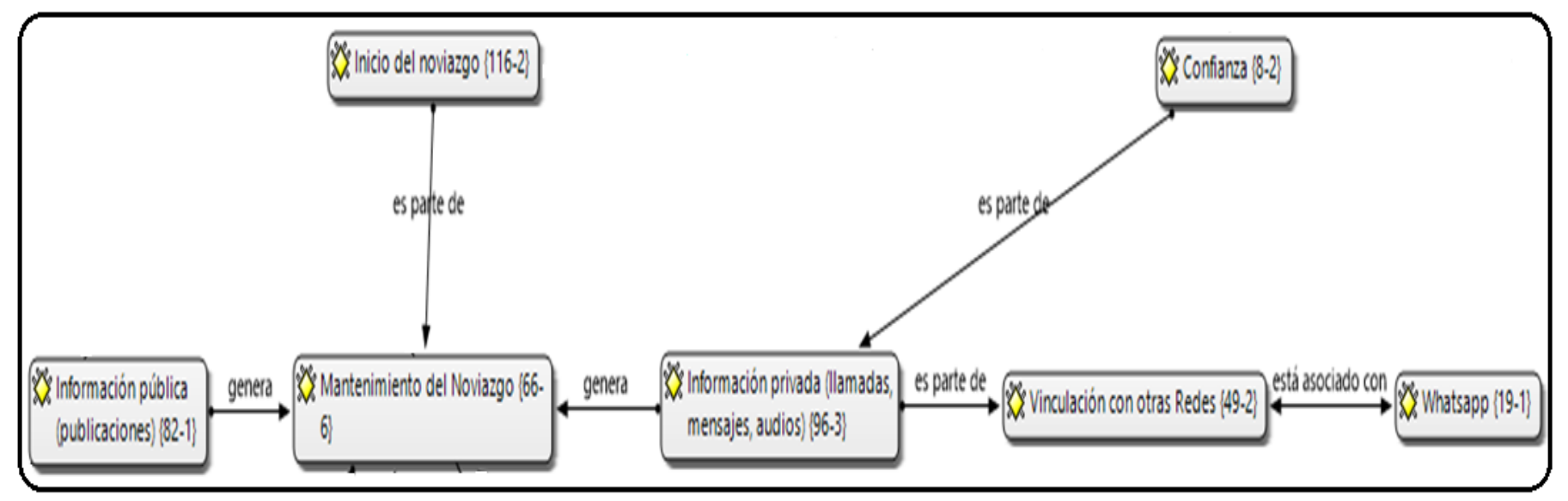

Figura 15. Mapa de Redes "Cuarta parte: El inicio y mantenimiento de la relación"

El inicio está vinculado con emitir la frase “¿quieres ser mi novia?”, así entonces, suceden cambios en la forma de dirigirse a la otra persona, incluida la presentación a los padres como una manera de denominar su relación; aunque por otra parte, se puede hacer público o no el noviazgo en Facebook, a través de los mensajes, la dedicación de canciones o poemas; los hombres son quienes optan por la vía privada mientras las chicas prefieren publicar información de manera que todos sus "amigos" puedan verla. Así pues, la información pública es un recurso para dar conocimiento a los demás de su relación y aunque la información privada puede ser también un medio para expresar palabras de amor, poemas o dedicar canciones, se utiliza para tocar asuntos más personales como los problemas y situaciones sexuales entre la pareja.

Por otra parte, la información privada no se enfoca solo en la comunicación a través de Facebook, pues para los entrevistados, la aplicación Whatsapp forma parte de la 
interacción, y mediante la construcción de la confianza optan por compartir su número de celular, agregándose a un medio que se complementa con Facebook.

\section{7) PRIMER ENCUENTRO}

\section{Desconfianza}

Después de esa constante interacción por medios públicos y privados, manifiestan interés y acceden a tener contacto físico, pero mantienen una desconfianza, ya que se sienten expuestos ante las inseguridades que enfrenta el país, recordemos que para el profesor Leobardo Hernández, maestro en Ciencias Computacionales por la Universidad Nacional Autónoma de México (citado en Excelsior, 2018), México utiliza el ciberespacio para cometer delitos como robo, extorsión y secuestros:

\begin{tabular}{|l|l|}
\hline Participante 3, Hombre & $\begin{array}{l}\text { “(..) ella pensaba que yo la iba a secuestrar, me decía "ah, sí quiero salir contigo } \\
\text { pero me da miedo que me secuestres” y le decia "no manches ipor qué te voy a } \\
\text { secuestrar?” "ah, porque ni te conozco, nos llevamos muy bien y sí me da miedo } \\
\text { salir contigo" y le decía "no, ve mi perfil, es como de una persona muy real de } \\
\text { foto”, entiendo su desconfianza”...” }\end{array}$ \\
\hline Participante 4, Hombre & $\begin{array}{l}\text { "(...) en esa época estaba eso del secuestro, trata de blancas y que las } \\
\text { enganchaban y justamente una semana antes sale ese reportaje de que } \\
\text { enganchaban a las mujeres con promesas y dije "bonito reportaje antes de que } \\
\text { vaya ¿no?”..." }\end{array}$
\end{tabular}

\section{El Otro Cotidiano}

Asimismo, que se dé el encuentro físico depende de la opinión de los padres, es decir, se necesita la aprobación de ellos para conocer físicamente a la otra persona; y recordemos que los padres presentan una idea orientada a la desconfianza e inseguridad sobre este tipo de relaciones (como vimos en apartados anteriores), así que en primera instancia les fue difícil realizar el viaje para visitar a su pareja.

\begin{tabular}{|c|l|}
\hline Participante 4, Mujer & $\begin{array}{l}\text { “(..) pues mis papás, son muy tradicionales, muy a la antigua y fue de "no, ¿cómo } \\
\text { vas a conocer en persona a alguien que conociste por internet? Puede ser alguien } \\
\text { malo” (...)” }\end{array}$ \\
\hline Participante 5, Mujer & “(...) mi mamá no quiere que vengas y pues hubo problemas familiares...” \\
\hline
\end{tabular}




\begin{tabular}{|l|l|}
\hline Participante 1, Hombre & $\begin{array}{l}\text { “(..) cuando le dije a mis papás de que la quería ir a ver y no me dejaron ¿qué } \\
\text { iba yo hacer en Puebla?, qué tal y si se trataba de una broma....” }\end{array}$ \\
\hline Participante 4, Hombre & “(...) yo quería ir pero sus papás no la dejaban...”” \\
\hline
\end{tabular}

Cuando a pesar de las dificultades logran verse de manera física, por lo regular se daba después de haberse establecido la relación de noviazgo (5 casos), mientras que solo 2 personas indicaron que fue antes, solo 1 dijo haberse visto con las chicas antes o después; y por último, 2 personas no tuvieron la oportunidad de conocer físicamente a su pareja, eso se muestra en los cuadros siguientes (y en la figura 16, Anexo 6):

Los que mencionaron haberse visto después de hacerse novios:

\begin{tabular}{|c|c|}
\hline Participante 2, Mujer & $\begin{array}{l}\text { "(...) le llegue a conocer pues sí me agradó, me gustó como me trató, muy } \\
\text { caballeroso, muy atento, entonces, para mí eso fue lo que fortaleció la relación } \\
\text { de que obviamente me dedicó su tiempo..." }\end{array}$ \\
\hline Parti & $\begin{array}{l}\text { “(...) fueron } 3 \text { años de platicar nada más así por Face y decir que éramos novios } \\
\text { y luego un día consiguió un vuelo en su trabajo...” }\end{array}$ \\
\hline Participante 5, Mujer & $\begin{array}{l}\text { "(...) yo empecé a andar con él en abril y me dijo "a lo mejor en diciembre voy” } \\
\text { y le dije "ah pues está bien"..." }\end{array}$ \\
\hline 1, Hombre & “(...) me quería sentir, me quería pues ya sabes (...) era mi primera vez...” \\
\hline Participante 4 , Hombre & $\begin{array}{l}\text { “(...) dijo "va, vamos a intentarlo” (regresa con ella), decidido compré los } \\
\text { boletos }(\ldots) "\end{array}$ \\
\hline
\end{tabular}

Aquellos que se conocieron antes de definir su relación:

\begin{tabular}{|c|l|}
\hline \multirow{2}{*}{ Participante 1, Mujer } & $\begin{array}{l}\text { “(..) me dice: ¿qué crees? Voy a ir a Guadalajara, y yo de i¿qué?! Porque no } \\
\text { éramos novios, ni nada, pero, todos los días hablábamos, (...) fue a cuando se } \\
\text { aventó a venir acá, de Veracruz hasta acá y ya, anduvimos....” }\end{array}$ \\
\hline Participante 6, Mujer & $\begin{array}{l}\text { (...) un día me dijo que pues nos viéramos en ese lapso (al salir de clases) y nada } \\
\text { más pues solo nos saludábamos (como amigos)...”" }\end{array}$ \\
\hline
\end{tabular}

Y por último, quien explicó que tanto antes como después de haberse visto definía su relación: 


\begin{tabular}{|l|l|}
\hline Participante 3, Hombre & $\begin{array}{l}\text { "(...) después de que hablábamos, salíamos y después de salir ya andábamos, } o \\
\text { a veces andábamos antes de salir...” }\end{array}$
\end{tabular}

\section{Contacto Físico}

Más allá de haberse visto físicamente antes o después de iniciar su relación, para los participantes la presencia física ayuda a conocer más a la persona, porque se accede a los gestos y a las acciones que se pueden ver de manera inmediata; de acuerdo con Simmel (1908), en nuestras relaciones sociales juegan un papel importante los sentidos sensoriales, para los entrevistados el primer encuentro permite conocer las cuestiones físicas ayudando a la comprensión de quién es el otro, un reconocimiento y rectificación de quién es, y si ya se conoció a la persona en foto se considera necesario comparar si se trata de la misma:

\begin{tabular}{|c|c|}
\hline Participante 1 , Mujer & $\begin{array}{l}\text { "(...) era tal cual me lo imaginaba, (...) él es alto, tal como en las fotos, no fue } \\
\text { como que una decepción (...) y ya nos abrazamos, duramos } 2 \text { minutos abrazados } \\
\text { y dije "no manches, eres real, sí existes", (...)" }\end{array}$ \\
\hline Participante 4, Mujer & $\begin{array}{l}\text { "(...) lo ubicaba de cara pero pues no sabía si se iba a parecer de idéntico en } \\
\text { vídeo, que en persona y ya lo vi, y fue como de "ah, ioh por dios!, ipor fin, después } \\
\text { de tantos años!, te tengo cerca, te puedo tocar y abrazar..." }\end{array}$ \\
\hline Participante 1 , Hombre & $\begin{array}{l}\text { "(...) Bueno cuando la vi la primera vez, pinche chingadera, estaba chiquitita } \\
\text { pero era muy cariñosa, todavía me acuerdo cómo es físicamente es chaparrita, } \\
\text { morenita, una sonrisa muy bonita, yo no me fijo por el físico, yo me fijo más por } \\
\text { los sentimientos, por la sonrisa, por la forma en que me ven..." }\end{array}$ \\
\hline
\end{tabular}

Para Eva Illouz (2007), la presencia física juega un factor importante en el desarrollo de la relación, pues si no hay un gusto por la apariencia del otro influirá en el seguimiento de lo que habían construido virtualmente; de acuerdo al cuadro anterior, para las participantes, el contacto físico ayudó a "corroborar" el aspecto que solo veían en fotos o vídeos, describiendo que era igual como lo habían imaginado, así que no fue una decepción.

\section{Afectividad Colectiva (Emociones)}

Para Pablo Fernández (2000) los sentimientos son singulares, sociales y relativos, definidos por las personas durante la sociabilidad y no se experimentan de la misma manera; para los entrevistados verse por primera vez genera el lloriqueo y los nervios como reacciones 
a lo anhelado porque la pareja se vuelve tangible, algo virtual que se traslada a la vida offline, es decir, para ellos es inusual ver a su pareja en comparación con alguien que establece y mantiene su relación prioritariamente de manera presencial:

\begin{tabular}{|c|l|}
\hline Participante 1, Mujer & $\begin{array}{l}\text { "(...) Si empecé a sudar, me sentí muy nerviosa y sentía que el corazón se me } \\
\text { quería salir y dije ino manches es él!... y seguía nerviosa, fue así como todo el } \\
\text { día dure emocionada y todo ese fin de semana, era la emoción de verlo, la risa de } \\
\text { emoción, nunca lo había sentido de esa forma fue muy extraño pero muy } \\
\text { bonito...” }\end{array}$ \\
\hline Participante 4, Mujer & $\begin{array}{l}\text { "(...) Ay, pues fue mucha emoción, una emoción muy grande, (...) y fue una } \\
\text { lloradera...” }\end{array}$ \\
\hline
\end{tabular}

\section{Ausencia de Contacto Físico}

Por otro lado, puede suceder que aunque consideren verse, el encuentro no se dé (para 2 participantes no hubo encuentro físico), debido a la imposibilidad de concretar el contacto físico o porque tuvieron problemas de comunicación:

\begin{tabular}{|l|l|}
\hline Participante 3, Mujer & $\begin{array}{l}\text { "(...) como que no le veo a esto caso porque dije "yo nunca voy a ir a Ecuador, } \\
\text { él nunca va a venir a México" dije "entonces, qué nos estamos haciendo } \\
\text { tontos"..." }\end{array}$ \\
\hline Participante 2, Hombre & $\begin{array}{l}\text { "...) Ya no nos llegamos a encontrar porque tuvimos problemas por lo que te } \\
\text { entonces, se ponía celosa y pensaba que yo lo apagaba propósito (...) Me harté } \\
\text { de todo eso...." }\end{array}$
\end{tabular}

Como señala Eva Illouz (2007), la presencia física es relevante para una relación amorosa, porque no hay manera de reemplazar las afectividades y las emociones que solo se generan cuando se toca físicamente a la persona que nos gusta o de la que estamos enamoradas; esto sucedió con la participante 3, pues considera necesaria la presencia del contacto físico en la relación, y cuando reflexiona que no podrá ser posible debido a la distancia y a las cuestiones económicas decide terminar con su noviazgo:

\begin{tabular}{|l|l|} 
Participante 3, Mujer & $\begin{array}{l}\text { “...) pregunte en cuánto estaban los boletos hasta Ecuador (...), salen carísimos } \\
\text { en ese entonces estaban en } 10 \text { mil pesos “¿qué? Ay, es mucho dinero” dije “no, }\end{array}$ \\
\hline
\end{tabular}




\begin{tabular}{|l|l|}
\hline & ahi muere" (...) "como que no le veo a esto caso" porque dije "yo nunca voy a ir \\
a Ecuador, él nunca va a venir a México" dije "entonces qué nos estamos \\
haciendo tontos"y entonces, agarre y lo corte."
\end{tabular}

\section{Diferencias (entre hombres y mujeres)}

Ahora, durante esta dinámica del primer encuentro físico, 5 de los participantes señalaron que es el hombre quien visita a la mujer, solo una de ellas mencionó haber sido quien viajó a la ciudad de su pareja, y en 2 casos acordaron verse en un lugar céntrico, como una cuestión igualitaria (figura 17, Anexo 6).

Se presentan los siguientes fragmentos, siendo el hombre quien viajó para ver a su pareja:

\begin{tabular}{|c|c|}
\hline Participante 1, Mujer & “(...) me dice: ¿qué crees? Voy a ir a Guadalajara, y yo de iqué!” \\
\hline Participante 4, Mujer & $\begin{array}{l}\text { "(...) un día consiguió un vuelo en su trabajo y me dijo "voy a ir a México a } \\
\text { verte” y dije "bueno", él viene a México..." }\end{array}$ \\
\hline Participante 5, Mujer & “(...) él vino hasta un año 9 meses ya de relación él llegó a venir para acá...” \\
\hline Participante 1, Hombre & $\begin{array}{l}\text { "(...) de hecho me fui a quedar con ella } 3 \text { días, viernes, sábado y domingo me } \\
\text { regrese como en la tarde cuando la vi (...) }\end{array}$ \\
\hline Participante 4, Hombre & $\begin{array}{l}\text { "(...) decidido compré los boletos nunca he viajado en avión (...) Llegó el } \\
\text { momento", los compré, le dije, yo estaba feliz..." }\end{array}$ \\
\hline
\end{tabular}

Ahora se presenta el caso donde la chica fue quien visitó a su novio:

\begin{tabular}{|c|l|}
\hline Participante 2, Mujer & $\begin{array}{l}\text { “(..) creo que ese día no fui a la universidad para conocerlo, entonces sí, fui a } \\
\text { visitarlo hasta allá...” }\end{array}$ \\
\hline
\end{tabular}

Por último, se muestra quiénes optaron por ponerse de acuerdo para verse en un lugar céntrico para ambos:

\begin{tabular}{|c|l|}
\hline Participante 6, Mujer & $\begin{array}{l}\text { “(..) yo salía pues a una hora y él entraba más o menos a esa hora entonces un } \\
\text { día me dijo que pues nos viéramos en ese lapso y nada más pues solo nos } \\
\text { saludábamos...” }\end{array}$ \\
\hline Participante 3, Hombre & $\begin{array}{l}\text { “...) con ella sí me veía en el centro, como que era el punto medio o sea nos } \\
\text { veímos el centro pues ya nos quedaba súper bien a los dos....” }\end{array}$ \\
\hline
\end{tabular}


Como se había comentado anteriormente, el hombre es quién propone la interacción de la pareja (buscando el contacto físico); mientras las chicas aceptan ser visitadas.

\section{Citas y Regalos}

En las citas posteriores como en el primer encuentro acuden a lugares significativos para alguno de los dos, es decir, se conocen los lugares que frecuentan. Durante su visita se dan regalos como muestra de afecto y atención:

\begin{tabular}{|c|c|}
\hline Participante 2, Mujer & $\begin{array}{l}\text { "(...) como cualquier relación física a lo mejor pues son detalles, sales a dar una } \\
\text { vuelta con tu pareja, todo era tan bonito..." }\end{array}$ \\
\hline Participante 4, Mujer & $\begin{array}{l}\text { "(...) Pues íbamos al Zócalo porque él se estaba quedando cerca de ahí, entonces } \\
\text { íbamos a Chapultepec, a la frikiplaza..." }\end{array}$ \\
\hline Participante 5, Mujer & $\begin{array}{l}\text { “(...) cómo te digo allá me llevó a conocer el ángel, el monumento a la } \\
\text { Revolución, Museo de Cera... ah, me llevó a comer tacos de tripa entonces ese es } \\
\text { un rito, (...) siempre he sido muy detallista con eso y él no es tan así, él es más de } \\
\text { comprarme cosas, siempre le he dicho "no me compres cosas mejor hazme tú } \\
\text { algo” (...) él se va me esconde una carta, yo igual le dejó una carta a veces } \\
\text { cuando yo me voy venir y le doy las gracias por todo lo que vivimos...” }\end{array}$ \\
\hline
\end{tabular}

\section{Fotos Juntos}

Durante estos encuentros físicos, se toman fotos donde la pareja aparece junta para después ser publicadas en sus respectivos muros, como una muestra de que están juntos y que el lazo afectivo se trasladó a lo físico, como una etapa dentro del mantenimiento de la relación. En otras palabras, se presenta ante la audiencia virtual (Lasén, 2012), una pareja que comparte momentos en la vida offline:

\begin{tabular}{|c|c|}
\hline Participante 1, Mujer & $\begin{array}{l}\text { "(...) pues nos empezamos a tomar fotos, y él puso la de perfil de nosotros, en la } \\
\text { que salimos juntos..." }\end{array}$ \\
\hline Participante 2, Mujer & $\begin{array}{l}\text { “(...) nos dimos la oportunidad de conocernos físicamente, pues yo subí una foto, } \\
\text { nos la tomamos precisamente en el centro de Toluca y ya la publique, (...) en la } \\
\text { foto creo me estaba dando un beso en la mejilla...", }\end{array}$ \\
\hline Participante 5, Mujer & “(...) siempre que él llega sube una foto "por fin juntos”..." \\
\hline
\end{tabular}




\section{Conocer a la Familia}

Por otra parte, una de las actividades que realizan (durante el primer encuentro o en citas posteriores), es visitar la familia del otro, ser presentados a los padres como una forma de reconocimiento y de aceptación, pues son los seres queridos que culturalmente se mantiene siempre una constante relación de apego:

\begin{tabular}{|c|l|}
\hline Participante 1, Mujer & $\begin{array}{l}\text { “(...) me decían mis papás que iban a ser una carne asada y yo les dije "¿puedo } \\
\text { invitarlo?” ya mis papá interactuaron más con él (...) estuvo ahí con nosotros, } \\
\text { con mi familia...” }\end{array}$ \\
\hline Participante 4, Mujer & $\begin{array}{l}\text { “(...) ni su familia ni nadie nunca me trataron mal, me dijo "te quedas aquí en la } \\
\text { casa”...” }\end{array}$ \\
\hline Participante 5, Mujer & $\begin{array}{l}\text { “(...) él me llevó hasta su cuarto para presentarme a su mamá que ya estaba } \\
\text { acostada y su papá pues ya en el carro lo conocí y a su hermana...” }\end{array}$ \\
\hline Participante 4, Hombre & "(...) llegué a su casa y todo, o sea me aceptaron bien...” \\
\hline
\end{tabular}

\section{Afectividad Colectiva (Emociones)}

Al finalizar los encuentros físicos, cuando cada uno regresa a su rutina diaria (a su lugar de residencia), de igual modo se presenta el lloriqueo y los abrazos como parte de la despedida. Llorar es un acto físico (una cuestión corporal) para expresar emociones, pues, los sentimientos son pragmáticos, en este caso, sirve para comunicar el sentir de la partida indefinida del otro. Para Pablo Fernández (2000), los sentimientos son objetos que no tienen nombre, y la única vía para comprenderlos es por medio del lenguaje, pero este al mismo tiempo se relaciona con lo vivencial, lo corporal y lo intuitivo, así entonces, las emociones descritas por la participante 1, las denomina desde el lenguaje como "nostalgia" y "tristeza", explicando que su vivencia de mantener un amor a distancia genera esos sentimientos:

\begin{tabular}{|c|l|}
\hline Participante 1, Mujer & $\begin{array}{l}\text { “(..) la nostalgia que ya es la tristeza de que ya se iba a ir, fue como muy sensible } \\
\text { antes de que se fuera ya quedamos ahí abrazados llorando como María } \\
\text { Magdalena...” }\end{array}$ \\
\hline Participante 5, Mujer & "(...) me tocó pues llevarlo al aeropuerto y lloramos los dos por la despedida...." \\
\hline Participante 1, Hombre & $\begin{array}{l}\text { "(..) me dio sentimiento pero no quería que me viera llorar, cuánto batallamos } \\
\text { para que llegará ese momento y llegó...." }\end{array}$ \\
\hline
\end{tabular}


Entonces, a continuación se presenta la vinculación de los códigos que tienen que ver con el Primer encuentro:

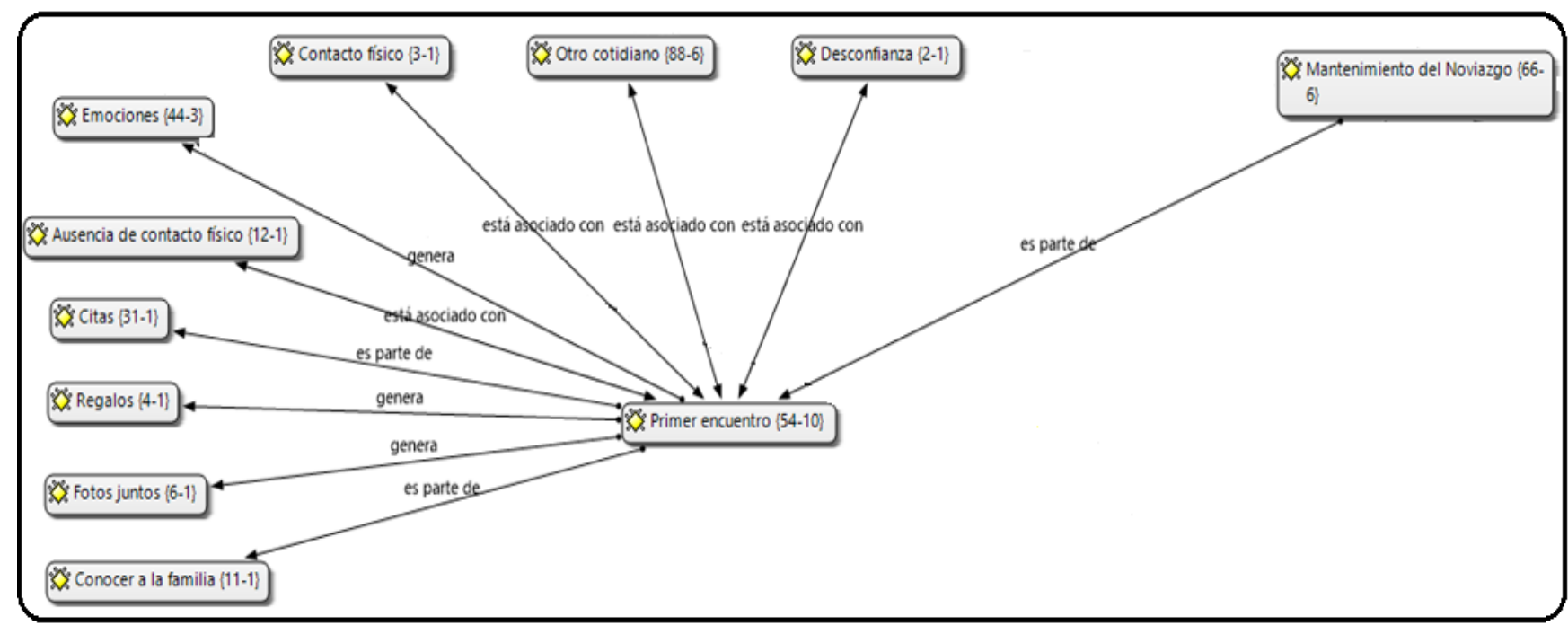

Figura 18. Mapa de Redes "Quinta parte: Primer encuentro"

Durante la constante interacción se genera la idea de verse por primera vez de manera física, la cual está permeada primero por la desconfianza, pues se duda de las intenciones de la otra persona, y por otra parte, el consentimiento de los padres, sin embargo, en la mayoría de los casos se da el encuentro en donde se constata que la persona "existe", es como se ve en fotografías, se acceden a los gestos y comunicación no verbal del otro y se presenta el nerviosismo al tener la oportunidad del contacto físico; donde las citas y los regalos están permeados de la vida cotidiana del otro, es decir, se visitan lugares significativos para el otro y se realizan obsequios para expresar su cariño como pareja, se toman fotos juntos como símbolo de unión y de presencia; sin embargo, también sucede que no logran establecer contacto físico lo que para ellos significa el final de la relación, pues consideran que no hay futuro.

\section{Constante Comunicación}

Después de verse físicamente y se da continuidad a la interacción, para los entrevistados, el mantenimiento de la relación se atañe a la comunicación. De acuerdo con los Sobreentendidos de Hofstatter (1966) y lo narrado por los participantes, el mantenimiento de la relación se debe a ciertas actividades "lógicas" como son las conversaciones frecuentes expresadas por llamadas y mensajes (información privada): 


\begin{tabular}{|c|c|}
\hline Participante 1, Mujer & “(...) platicábamos cada 3 días, le mandaba mensajes...” \\
\hline Participante 2, Mujer & $\begin{array}{l}\text { "(...) diario me mandaba un mensaje "Hola, buenos días, bonita" "te quiero } \\
\text { mucho", entonces como que esos mensajes te van ganando como si la persona lo } \\
\text { vieras diario o cada tercer dí..." }\end{array}$ \\
\hline Participante 5, Mujer & $\begin{array}{l}\text { "(...) toda las noches hablamos, nos hablamos durante el día ahora hay más } \\
\text { posibilidad porque ya está el WhatsApp..." }\end{array}$ \\
\hline Participante 1 , Hombre & $\begin{array}{l}\text { "(...) pasábamos horas platicando, o sea ponle tú empezábamos a las } 9 \text { y } \\
\text { terminábamos a las 3, } 4 \text { de la mañana..." }\end{array}$ \\
\hline Participante 2, Hombre & $\begin{array}{l}\text { "(...) se veía al interés, se veía, era muy comunicativa, voy a hacer esto, voy a } \\
\text { hacer lo otro, así durante el día, voy a comer esto ¿no? mira que no sé qué, estoy } \\
\text { tomando mate, mi mamá te manda saludos..." }\end{array}$ \\
\hline
\end{tabular}

\section{Imágenes/Fotos significativas para ambos}

Esta comunicación constante está relacionada con el recurso visual (imágenes, vídeos y texto), pues expresan sentimientos, emociones, situaciones dependiendo del contexto social. La pareja comparte u obsequia imágenes de acuerdo a sus gustos e intereses; para la participante 2 Mujer, las que más recuerda están relacionadas con la expectativa y los planes a futuro, un anhelo de pensar qué pasará si su noviazgo continúa, la idea de formar una familia tradicional está relacionada con papá, mamá e hijo. Por otra parte, para el participante 2 Hombre, fueron un regalo para su novia de acuerdo con los intereses en común, a través de conocer al otro se accede a la información personal y significativa, y aquí ambos estaban interesados por las obras de arte como las pinturas:

\begin{tabular}{|c|l|}
\hline \multirow{5}{*}{ Participante 2, Mujer } & $\begin{array}{l}\text { “...) recuerdo una imagen que estaba muy graciosa porque era como un helado } \\
\text { y un foquito ahorrador, y que en medio era un niño en forma de helado con } \\
\text { foquito, como un conito, dentro del helado con cabello o cabecita de foco, era } \\
\text { nuestra imagen que actualmente lo llegamos a ver y me dice, “mira, esta imagen } \\
\text { me recuerda a ti”.... creo que él me lo publicó, y me decía “Ah, mira, nosotros en } \\
\text { un futuro”, que él era el helado y yo era el foco y el foquito... nos demostrábamos } \\
\text { ese cariño por medio de las imágenes...” }\end{array}$ \\
\hline Participante 2, Hombre & $\begin{array}{l}\text { "...) yo le regale dos imágenes que no las encuentras fácilmente, o sea en Google } \\
\text { un artista, que es donde dos personas están entrelazadas un hombre y una mujer }\end{array}$ \\
\hline
\end{tabular}




\section{Planes a futuro}

Cuando se presenta una constante comunicación y se tiene conocimiento de quién es el otro (sus gustos y metas) emerge una norma social (Hofstatter, 1966), la cual indica que las conversaciones largas y constantes generan fortaleza y continuidad en la relación, si esto se mantiene se crea la expectativa de los planes a futuro ligados con el casamiento, tener hijos y vivir juntos. Lo que va a acorde con su concepción del amor (explicada en el primer apartado del análisis), pues se necesita de atención e invertir tiempo para que la relación se desarrolle:

\begin{tabular}{|c|c|}
\hline Participante 1, Mujer & $\begin{array}{l}\text { “(...) tenemos cosas en común, (...) de que queríamos los dos lo mismo, a veces } \\
\text { bromeamos de que no nos queremos casar, de que no queremos tener hijos...”" }\end{array}$ \\
\hline Par & “(...) "pues sí, esperemos así durar mucho t \\
\hline Parti & $\begin{array}{l}\text { "(...) bueno empezamos a hacer preparativos de boda pero yo estaba todavía en } \\
\text { la universidad...” }\end{array}$ \\
\hline Participante 1, Hombre & $\begin{array}{l}\text { “(...) no sé, yo sentía que me iba a quedar con ella (...) yo sentía que me iba a } \\
\text { juntar con ella, que me iba a casar con ella..." }\end{array}$ \\
\hline Participante 2, Hombre & $\begin{array}{l}\text { “(...) ya teníamos un proyecto de vida, no quedarnos siempre así de lejos o } \\
\text { virtual, si no ya de vernos, de hacer un proyecto de casarnos, de yo irme para allá } \\
\text { a vivir a Argentina, Buenos Aires, entonces se suponía que era serio ¿no?...” }\end{array}$ \\
\hline
\end{tabular}

Para Finkel, et al. (2014) y Esteinou, (2017), las relaciones de pareja actuales están basadas en el compañerismo, en conocer al otro y satisfacerse (sentirse bien a lado del otro); y de acuerdo con las entrevistas, llevarse bien y mantener una comunicación constante genera expectativas, las cuales están muy ligadas a vivir juntos, formando parte del siguiente paso en la relación ¿pero qué pasa cuando ocurre lo contrario, es decir, comienza un descontinuo saber del otro? Antes de contestar esta pregunta, es prudente observar la sexta parte del Mapa de Redes para observar la conexión que tienen los códigos (Mantenimiento del noviazgo, Constante comunicación, Imágenes/Fotos significativas para ambos y Planes a Futuro): 


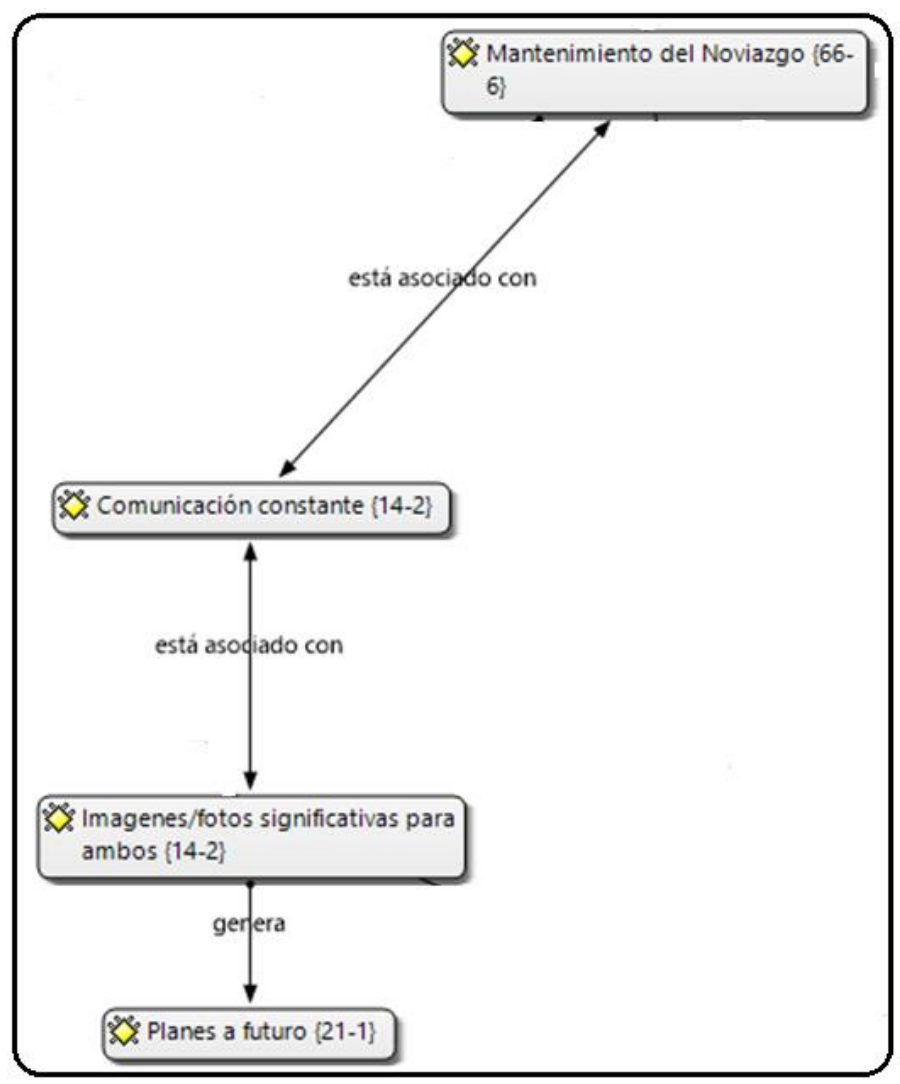

Figura 19. Mapa de Redes "Sexta parte: Comunicación constante un "indicador" para hacer planes a futuro"

La comunicación constante crea sobreentendidos de lo que se espera del noviazgo, es decir, para los entrevistados no perder la comunicación resulta alentador para la continuidad de su relación, por lo que, se comienza a pensar en futuro.

\section{Poca comunicación}

En otras palabras, "la norma del interés" se sustenta a partir de la comunicación constante, y cuando pasa lo contrario donde la otra persona deja de ser comunicativa, se interpreta como un indicador de que la relación va por otro camino lejos de los planes a futuro:

\begin{tabular}{|l|l|}
\hline Participante 1, Hombre & $\begin{array}{l}\text { (...) cuando yo platicaba con ella ya la sentía muy cortante, ya no sentía las } \\
\text { conversaciones como antes, yo estaba listo para que ella me dijera que } \\
\text { termináramos, yo sabia que eso iba a pasar...” }\end{array}$ \\
\hline
\end{tabular}




\section{Vistos}

Para los entrevistados, si se genera la poca comunicación se predice el final, acciones como dejar en visto o evitar la comunicación para ellos son "entendidas" como señales de que la relación puede finalizar:

\begin{tabular}{|c|l|}
\hline Participante 2, Mujer & $\begin{array}{l}\text { “...) Ya no me contestaba los inbox o me los contestaba un día después o creo } \\
\text { que en ese entonces todavía no estaban los famosos "vistos” pero si aparecía una } \\
\text { palomita pues ya sabías que ya lo había visto, entonces le fui perdiendo interés y } \\
\text { también me fui alejando de ese tipo de situación...” }\end{array}$ \\
\hline Participante 2, Hombre & $\begin{array}{l}\text { “...) yo veía que me dejaba mucho en visto, ya no me contestaba, decía que } \\
\text { estaba hablando con sus amigas y que tenía que hablar con alguien más que no } \\
\text { fuera yo...” }\end{array}$
\end{tabular}

\section{Bloqueo y Eliminación}

Después de visualizar esas señales de “desinterés" y poca comunicación, por lo regular la situación es irremediable, dando por concluida la relación. Se presentan situaciones en las que uno de los dos termina por eliminar o bloquear al otro:

\begin{tabular}{|c|c|}
\hline Partic & $\begin{array}{l}\text { "(...) lo que hizo esta persona fue bloquearme o me eliminó e hizo otra cuenta y } \\
\text { bueno, ahí me ves llorando...” }\end{array}$ \\
\hline & (...) bor \\
\hline Parti & $\begin{array}{l}\text { “(...) me acuerdo cuando le dije que no me hablara, oyó el audio que le mandé y } \\
\text { su reacción primero fue borrarme...” }\end{array}$ \\
\hline Partici & $\begin{array}{l}\text { "(...) les mandaba esa carta que siempre era de media cuartilla, se las dejaba en } \\
\text { Facebook y las bloqueada totalmente y no sabía nada de ella..." }\end{array}$ \\
\hline
\end{tabular}

Aunque la poca comunicación, los vistos, la eliminación y el bloqueo pueden ser "indicadores" de la finalización de la relación, también se presenta otra perspectiva, pues debido a esa inversión de tiempo, se considera que dejan de lado otras cuestiones cotidianas:

\begin{tabular}{|c|c|}
\hline Participante 3, Mujer & $\begin{array}{c}\text { “...) “¿por qué no me contestas?” "Pues es que estoy despachando, es que estoy } \\
\text { ocupada”, me empezó a fastidiar porque empecé a ver eso que mi negocio se } \\
\text { estaba descuidando y es de lo único que vivimos, o sea mi hija y yo....” }\end{array}$ \\
\hline
\end{tabular}




\begin{tabular}{|l|l|}
\hline Participante 3, Hombre & $\begin{array}{c}(. . .) \text { fíjate que cuando tenían hijos no se podía hacer tanto la interacción, (...) } \\
\text { porque cómo tenían al niño, andaban cuidándolo.... }\end{array}$
\end{tabular}

En otras palabras, mantener la constante comunicación genera descontento porque dejan de lado responsabilidades de su vida offline, así que prefieren dar por terminada la comunicación o la relación.

\section{8) FIN DEL NOVIAZGO}

\section{Diferencias (entre hombres y mujeres)}

De acuerdo con lo mencionado por los participantes que terminaron su relación (5 casos en total), por lo regular son los hombres quienes la dan por terminada (4 casos), y solo 1 mujer explica que ella terminó con el noviazgo (figura 20, Anexo 6). A continuación se presenta el cuadro con los fragmentos de las entrevistas que ilustran esto:

\begin{tabular}{|c|c|}
\hline Participante 2, Mujer & $\begin{array}{l}\text { “(...) llegó un momento en el que me dijo “¿sabes qué? mejor hasta aquí la } \\
\text { dejamos porque no quiero hacerte daño y pues estoy estudiando o trabajo y no } \\
\text { puedo seguir con la relación”...." }\end{array}$ \\
\hline Participante 3, Mujer & $\begin{array}{l}\text { “(...) le empecé a explicar "me quitas el tiempo, yo económicamente ya no estoy } \\
\text { percibiendo lo que debo de percibir”, y él me empezaba a rogar y yo de "no, ya } \\
\text { no quiero saber nada de ti”..." }\end{array}$ \\
\hline Participante 1, Hombre & $\begin{array}{l}\text { "(...) me acuerdo que le dije si quieres ya vete, (...) llegue a mi casa, me acosté, } \\
\text { me puse a reflexionar..." }\end{array}$ \\
\hline Participante 2, Hombre & $\begin{array}{l}\text { "(...) le dije que si me hablaba o me escribía o algo, la iba a bloquear no quería } \\
\text { que me diera explicaciones..." }\end{array}$ \\
\hline Participante 3 , Hombre & $\begin{array}{l}\text { "(...) Yo tenía una carta (...) que decía "me la pasé muy bien contigo pero poco } \\
\text { a poco nos hemos sido desconociendo ya se ha acabado la magia” porque } \\
\text { siempre seguía con mi romanticismo y ya nada más se las ponía y las } \\
\text { bloqueaba..." }\end{array}$ \\
\hline
\end{tabular}

Entonces, en estos casos específicos, los hombres son quienes por lo regular dan el primer paso, inician el coqueteo, proponen a las mujeres comenzar un noviazgo, viajan a conocer físicamente a su pareja, y posteriormente ser ellos quienes la den por finalizada. De acuerdo, con Lasén y Puente (2016), las Tecnologías de la Información y la Comunicación 
participan en el proceso de la relación de pareja, es decir, no nos desligamos de nuestras tradiciones así que la manera de interactuar en el mundo virtual parte de nuestra concepción del amor y sus pautas de acción a seguir y por otro lado, el mundo de significado que se construye en la interacción online que nos dice cómo navegar.

Se identifica que en general, las relaciones iniciadas a través de Facebook, terminan porque se muestra desinterés; en otras palabras, las acciones (dejar de ser comunicativo y expresivo) "indican" el final.

\section{Afectividad Colectiva (Emociones)}

Al dar por terminada la relación, se presenta el acto de llorar debido a la pérdida que se experimenta; de acuerdo con Blondel (citado en Fernández, 1994), una vez definidas las emociones se construyen patrones, los cuales servirán como guía en las interacciones sociales, así entonces, ellos comprenden que finalizar la relación está asociada con el dolor y el acto de llorar:

\begin{tabular}{l|l} 
Participante 2, Mujer & $\begin{array}{l}\text { “...) sí sufrí, sí lloré la relación cuando esa persona pues ya no mostraba } \\
\text { interés...” }\end{array}$
\end{tabular}

\section{Mantener contacto por redes sociales y Encuentros sexuales}

Después de la ruptura solo dejan de tener contacto por un tiempo, pues vuelven a agregarse a sus redes sociales como Facebook, lo que genera la posibilidad de seguir viendo lo que el otro hace a pesar de haber terminado la relación. Esto fortalece la idea de un mundo de exhibición, de la posibilidad de mostrar lo que queremos que otros vean:

\begin{tabular}{|c|l|}
\hline \multirow{5}{*}{ Participante 2, Mujer } & $\begin{array}{l}\text { “...) pasaron como dos o tres meses y me mandó una solicitud de nuevo, dije } \\
\text { "bueno” y desde ahi lo he tenido en Facebook he visto que igual a iniciado otras } \\
\text { relaciones (...) actualmente sigo teniendo comunicación con él, como que de } \\
\text { repente me volvió otra vez a tirar la onda, (...) pero sí después de esa ruptura, de } \\
\text { esa eliminación sí me seguí contactando con él...” }\end{array}$ \\
\hline Participante 1, Hombre & $\begin{array}{l}\text { “...) mi relación con ella la puedo dar por terminada y hasta ahorita te digo que } \\
\text { la tengo en Facebook pero ya no platico con ella, se podría decir como una } \\
\text { conocida nada más...” }\end{array}$ \\
\hline
\end{tabular}




\begin{tabular}{|l|l|}
\hline Participante 3, Hombre & $\begin{array}{l}\text { "...) ellas me cuentan su vida y me piden consejos y les digo que hacer y qué no } \\
\text { hacer..." }\end{array}$
\end{tabular}

En algunos casos, se citan de nuevo para tener encuentros sexuales dejando de lado la parte romántica y la relación "amorosa" que alguna vez establecieron:

\begin{tabular}{|l|l|}
\hline Participante 2, Hombre & $\begin{array}{l}\text { "(...) Todavía la de Puebla me busca para cosas sexuales, la veo como muy } \\
\text { enganchada, una vez tenía novio y vino aquí para ¿qué crees? teniendo novio...” }\end{array}$ \\
\hline Participante 3, Hombre & $\begin{array}{l}\text { "(...) yo digo que con el 60\%, después me volvían agregar, (...) yo creo que con } \\
\text { el } 50 \% \text { volvía a salir y ya no era algo tierno, era algo más carnal como sexo } \\
\text { casual, y actualmente tengo a la mayoría de ellas...”" }\end{array}$ \\
\hline
\end{tabular}

Por tanto, no se cierra del todo la comunicación entre ambos, sin embargo, toma otro rumbo, comprende otros intereses, es decir, la relación de pareja se transforma a una relación casual sin sentimientos de amor, se vuelve práctica para satisfacer otro tipo de deseos. Así pues, se muestra la última parte del Mapa de Redes, en la cual se menciona la relación que tienen los códigos: Poca comunicación, Vistos, Bloqueo, Eliminación, Fin del noviazgo, Emociones, Encuentros sexuales y Mantener contacto en Redes Sociales: 


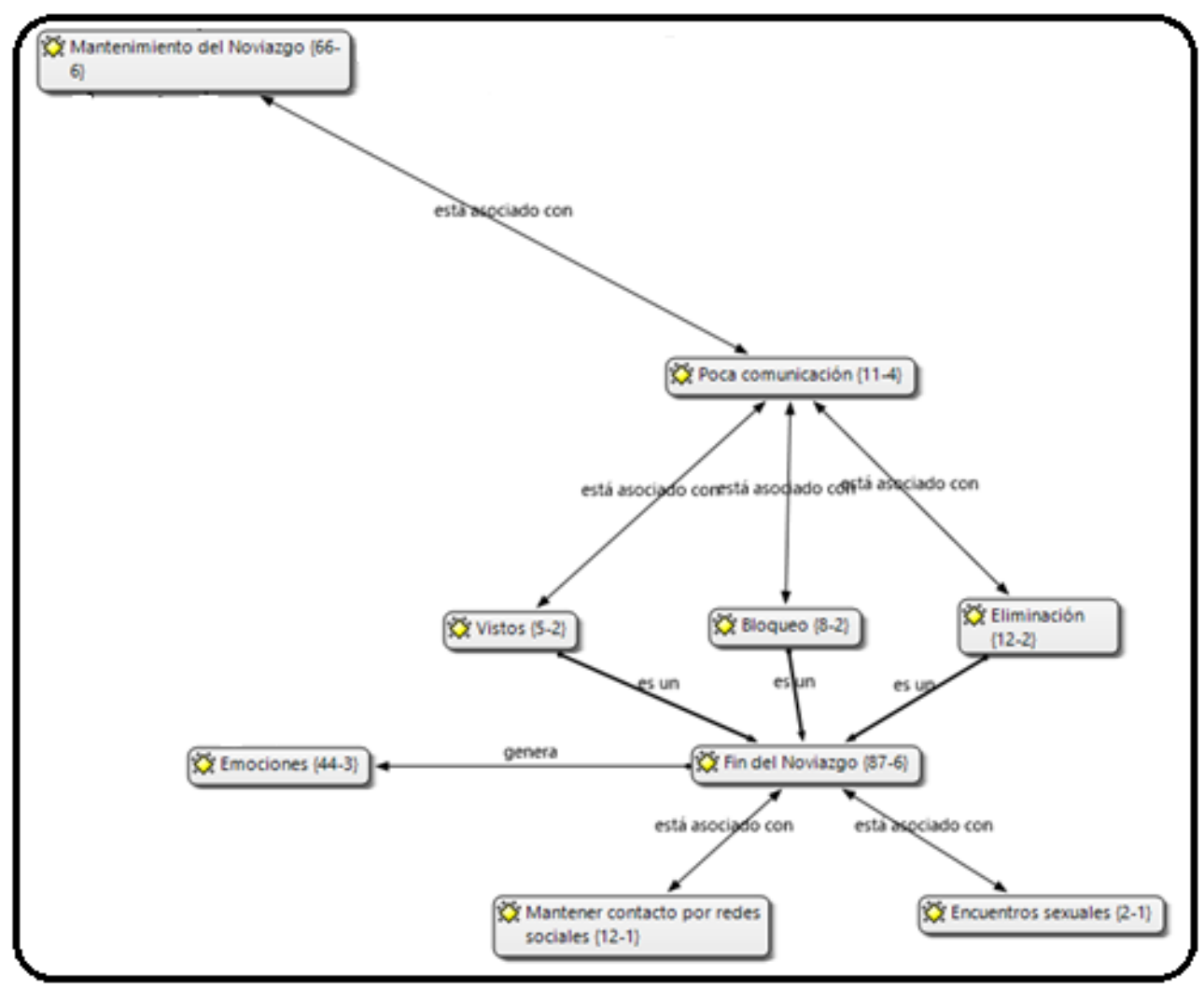

Figura 21. Mapa de Redes "Séptima Parte: Poca comunicación indicio del fin"

La poca comunicación, los vistos, el bloqueo y/o la eliminación en las redes sociales genera la expectativa del fin, donde se llora la pérdida, pero se mantiene aún el contacto pasando el tiempo, al menos para saber qué hace el otro, incluso se da la oportunidad de volver a verse aunque la dinámica cambia, convirtiendo el noviazgo a una relación más casual y carnal.

¿Por qué los participantes inician y mantienen relaciones de noviazgo a través de Facebook?

Y finalmente, para los participantes iniciar y mantener una relación de noviazgo se debe a varias razones, porque surge de manera paulatina conforme la interacción avanza, o porque querían experimentar algo nuevo, o señalan que era algo que encontraron y no podían obtener de su vida offline. Por lo tanto, aparecen temas como la idea de la convivencia como generadora de lazos afectivos; la idea de vivir cierta situación porque se ha escuchado de ella; y por último, la necesidad afectiva, sentirse comprendido por una persona que se comunica solo por el medio virtual comparando así que sus relaciones cara a cara no lo satisfacen de manera emocional: 


\begin{tabular}{|c|c|}
\hline Participante 6, Mujer & “(...) Pues empezamos a salir un poco más (...) empezamos a convivir más...” \\
\hline Participante 3, Mujer & $\begin{array}{l}\text { “(...) Experimentar esa sensación de tener un novio por Face, yo nunca había } \\
\text { tenido, yo siempre lo había escuchado y yo dije "vamos a ver qué se siente” “¿qué } \\
\text { puede pasar él hasta allá y yo acá?” y sí lo pensé "el día que ya no quiera algo } \\
\text { pues ya no le contesto y a ver que haga algo”...” }\end{array}$ \\
\hline Participante 4, Hombre & $\begin{array}{l}\text { “(...) Porque decía las cosas que necesitaba escuchar (...) Y ella me decía } \\
\text { "imagínate que te estoy abrazando" entonces eran de esas pocas veces que decía } \\
\text { "ella es", nadie me había dicho "ven, por lo menos imaginar, ven te abrazo”, por } \\
\text { eso me gustó ella..." }\end{array}$ \\
\hline
\end{tabular}




\section{CAPÍTULO 7. CONCLUSIONES}

El establecimiento de las relaciones de pareja a través de Facebook se ha vuelto parte de nuestra vida cotidiana y sus elementos que lo conllevan muchas veces no los vemos, o no reflexionamos como es que se construye, se mantiene y finaliza.

La concepción que tenemos y compartimos con otros sobre el noviazgo y el amor son un parteaguas para comprender la dinámica que se da a través de las redes sociales como Facebook, pues los participantes al estar permeados por esta sociedad y su manera de pensar sobre las relaciones afectivas hace que ellos las consideren o no similares a las establecidas de manera presencial.

Además los códigos sociales en nuestras relaciones de noviazgo se basan en la interacción, en el conocimiento y la exploración de quién es el otro, construyendo así una intimidad, para los entrevistados esos elementos forman parte de su concepción del amor, llevándolo a la práctica en este ámbito virtual.

Asimismo, el mundo virtual, en específico Facebook es un espacio donde se crean sobreentendidos, reglas que seguir para entender e interpretar las acciones de los otros: ¿por qué me dio like a mi foto? Para los entrevistados es interpretado como interés, de coqueteo, una forma de acercarse y comunicarse, ¿pero cómo saben esto?

En la red existen protocolos y reglas de convivencia aceptadas a partir de la negociación, es decir, gracias a las experiencias de los otros y las propias se va creando un

mundo de significado; códigos de convivencia que vamos optando y compartiendo; una guía que nos indica por dónde y cómo navegar, por lo tanto, las fotos como forma de presentación del "yo" y de la pareja, los likes y los comentarios como parte de la dinámica de la primera interacción, las indirectas y halagos como coqueteo, plantear la frase "¿quieres ser mi novio?" para iniciar la relación de pareja, los vistos, el bloqueo y la eliminación interpretados como desinterés y finalización.

Primero que nada debemos entender la perspectiva y posturas de las personas cercanas (familiares, amigos, conocidos) porque esto influye en las decisiones de la persona que comienza una relación de noviazgo a través de Facebook, en otras palabras, las creencias 
y los pensamientos de los otros intervienen en las decisiones que se toman durante el noviazgo.

De acuerdo a la pregunta de investigación “¿cómo se inician, se mantienen y finalizan las relaciones de pareja a través de Facebook?" Las personas entrevistadas indican que el proceso de la relación inicia con agregar a alguien como amigo, a partir de la selección e interpretación, es decir, a partir de la convivencia en grupos/páginas de Facebook, a través de navegar en los perfiles de personas en común o considerando los lugares físicos, comenzamos a conocer a los demás usuarios, quién comenta, quién me da "like", quién aparece como amigo de mi amigo, quién vive en mi vecindario, etc.

Entonces, se presentan diferentes formas de agregar "amigos", sin embargo, se toman ciertas medidas de seguridad o selección, es decir, no todas las solicitudes de amistad son aceptadas ni a cualquiera se les envía, ¿cómo es esto?

En el caso de las mujeres mencionaron usar el stalkeo para identificar quién les envía solicitud, a través de revisar el perfil (información y fotos) y así evaluar si se trata de una cuenta "real" o "falsa", en otras palabras, hay medidas de seguridad que van guiando al usuario y construyendo la confianza para después interactuar; en este aspecto, las fotografías juegan un papel importante en el conocimiento de quién se trata, y por otro lado, los hombres usan este recurso para visualizar posibles amistades a partir de la atracción física, es decir, se evalúan las fotos de cada usuaria para después enviar la solicitud de amistad y posteriormente comenzar con la conversación; así identificamos el papel que juega el lenguaje visual en la construcción de la relación.

Los términos de confianza e intimidad se hacen presentes porque al evaluar y platicar con la persona, se comienza a acceder a cuestiones más personales como gustos y problemas. La constante comunicación construye el ambiente de coqueteo, de insinuaciones y comentarios ligados a un interés más en específico; la relación se vuelve diferente gracias al lenguaje, y marca una diferencia en la convivencia a partir de frases como “¿quieres ser mi novia?” o “qué tal si salimos?”; y así después surgen las publicaciones a través de imágenes y canciones referentes a lo que conocemos cotidianamente como el amor de pareja. Asimismo, ya que se conocen pueden compartir su número telefónico para comenzar a hablar 
de manera más privada, sin dejar de lado la información pública como canciones (vídeos musicales), imágenes y fotos juntos que otros pueden ver.

La vida privada y la vida pública se representan a partir de lo que se publica en los muros pero también a partir del chat aunque no exclusivamente por Facebook, pues con la integración de otras aplicaciones como WhatsApp ambas se complementan debido a sus variados recursos visuales como las fotografías, los memes, los comentarios, los “likes", los audios, las vídeollamadas, etc.; en su utilización se toman decisiones de qué información se comparte de manera pública y cuál es privada; en este aspecto, no todos deciden mostrar su relación de noviazgo, como una forma de existencia y de aprobación por parte de una audiencia, optando por comunicarse a través de los mensajes (en el caso de los hombres).

La información más privada como los conflictos, las rupturas y los momentos sexuales suelen solo escribirse a través de los mensajes privados manteniendo así aspectos de la vida cotidiana aún reservados solo para la pareja.

Durante esas conversaciones se genera el interés de conocerse cara a cara aunque con algunas dificultades por parte de la oposición de los padres, sin embargo, cuando se lleva a cabo surgen otros elementos en la relación como los regalos y la presentación de la pareja a los padres. Así entonces, la familia facilita o dificulta el primer encuentro, pues estamos en una cultura muy apegada a nuestros seres queridos donde se necesita de su aprobación. Aunque el inicio del noviazgo se dé online, trasladar la relación a un contacto físico es parte del mantenimiento, si no llega a darse, para ellos es un indicador de que no hay futuro en la relación.

De acuerdo con los objetivos específicos, se identificó la afectividad colectiva, pues las emociones están presentes en todo el proceso de la relación de pareja, desde el inicio que comienza con un miedo por la incertidumbre de no saber de quién se trata o con quién se está hablando; hasta la emoción de verse por primera vez cara a cara, y la tristeza que causa su término, siendo el lloriqueo una expresión física de estos 2 diferentes momentos.

Se han construido las formas de mantenimiento y dar por finalizado el noviazgo, la eliminación y el bloqueo son parte del fin, aunque esto es momentáneo ya que se opta por regresar a tener contacto, aunque la comunicación ya no sea la misma, pero se tiene 
conocimiento del otro (qué hace y qué otras relaciones establece). Además, los vistos o no contestar los mensajes es considerado una señal para comprender el desinterés, los participantes interpretan que si ya no hay comunicación ya no hay amor, por lo tanto, ya no hay futuro en la relación; pero si pasa lo contario se crea la perspectiva de una vida juntos, se idealiza la relación ya que para ellos hay elementos suficientes que generan confianza de que la relación va bien y puede institucionalizarse o formalizarse. Entonces, para ellos la concepción de la pareja toma sentido cuando se muestra "interés" por el otro, y el amor es interpretado como una dedicación de tiempo, consistente y material (la necesidad de verse físicamente en algún momento).

Como pudimos observar se identifican varias diferencias entre mujeres y hombres respecto a la concepción del amor y el uso de Facebook. Por un lado, sigue la diferenciación de roles, donde el hombre toma la iniciativa y la mujer acepta o da indicadores de la continuidad de la interacción o relación. Las Tecnologías de la Información y la Comunicación (TIC) participan en las relaciones íntimas tradicionales desde el cortejo hasta su ruptura, es decir, el uso de redes sociales como Facebook está permeado de nuestras costumbres y pensamientos cotidianos que llevamos a cabo en la vida diaria.

Por lo que, en el uso de Facebook, son los chicos los que acuden a visitar los perfiles y evaluar las fotos (mediante el atractivo físico) para después enviarles solicitudes de amistad a las mujeres; en cambio las chicas optan por revisar el perfil del otro para saber quién es y aceptar las solicitudes que le llegan; así pues, son ellos los que tienen más experiencias en establecer una relación de pareja a través de Facebook, siendo la mujer su primera vivencia. Asimismo, ellos comienzan la interacción por medio de mensajes y dan inicio al coqueteo, mientras ellas reciben las indirectas, jugando así una dinámica social.

Por otra parte, los hombres acuden a visitarlas; y son ellos quienes utilizan más el medio privado (mensajes y llamadas) para interactuar con su pareja, así como también dan por finalizada la relación; pero aunque ellos tomen el primer paso, son ellas las que dan “indicadores” de aceptación, pues hay que recordar que ambos son parte del noviazgo y sin uno de los dos la interacción no tendría sentido. 
Asimismo, aunque habrá algunas diferencias, todos los participantes saben cómo navegar, cómo se interpretan las acciones suyas y la de otros, creando un mundo de significado, pero lo que sí cambia, son las dinámicas a seguir ¿quién lo hace primero?

Para finalizar, la comprensión del por qué las personas optan por tener este tipo de relaciones de pareja, está enfocada en tres aspectos diferentes, por un lado, debido a que la interacción continúa hizo posible la construcción del noviazgo; también se presentaba la oportunidad de experimentar algo nuevo; y por último, se debe a la necesidad afectiva, pues halló la comprensión y atención en alguien que no estaba presente en su vida offline. La relación de noviazgo a través de Facebook es un proceso, en el cual toman sentido la información pública y privada, el primer encuentro, el reconocimiento y opiniones de los otros, así como las costumbres y reglas sociales establecidas en nuestro contexto social donde el hombre toma la iniciativa.

\section{Reflexiones Finales}

Estamos ante una plataforma que a sus 15 años de creación y de llegar a nuestras manos a través de una computadora para después tenerla en los teléfonos móviles, sin duda ha modificado nuestra forma de comunicarnos (usando likes, hacer comentarios en las fotos o mandar solicitudes de amistad a partir del stalkeo), sin embargo, la forma de navegar parte de nuestras tradiciones y costumbres, es decir, al interactuar en un contexto socio histórico que nos dice "qué esperar" y "cómo debe ser" el noviazgo heterosexual, es la guía que tomamos en consideración para movernos en este mundo virtual. Entonces, las interacciones en un espacio físico son el parteaguas para saber qué códigos de etiqueta y convivencia "debemos" usar.

Facebook te da la pauta para crear un "yo", para seleccionar tus amistades y amores, sin embargo, lo permeado por la cultura como, qué se espera en el noviazgo y qué tipo de hombres o mujeres nos gustan, están vinculados a nuestra manera de pensar como sociedad, donde la asignación de roles tiene fuerza. Así que no nos desprendemos de los significados que construimos socialmente.

Así entonces, no se modifican los roles sociales establecidos y asignados desde la cultura y la construcción del pensamiento; los roles de pareja incluso de familia como el hijo 
se manifiestan, se consulta a la madre para tomar decisiones ¿por qué? Porque estamos en un contexto socio histórico donde la madre es un pilar importante en la persona, "ella da la vida por nosotros" "no hay mejor consejo que el de una madre".

Satanizar el uso de las redes sociales porque se considera un "sustituto" de las relaciones cara a cara me parece que no es pertinente, pues, aunque tengamos la posibilidad de establecer relaciones a través de Facebook se busca la presencia física, de lo contrario no hay futuro en la relación, y mientras se llega a ese encuentro físico las vídeo llamadas, los audios y las fotos serán recursos necesarios para "conocer" y "acercarse" al otro.

Esto me hace preguntar ¿en 100 años cómo será?, ¿qué nos depara?, ¿seguiremos arraigados a nuestras costumbres y tradiciones sobre el amor y la pareja?, ¿por qué seguimos reproduciendo esas formas de acción?, ¿qué nos hace pensar y actuar de esa manera?, ¿si se busca el contacto físico en la relación, será que estaremos de acuerdo en usar la realidad virtual porque los sentidos sensoriales “indican” que estamos ante una interacción "social”?, Hay mucho por comprender, por lo que queda un camino muy largo que recorrer.

Tal vez en más de 100 años estas discusiones serán resueltas, ya que los avances tecnológicos están constantemente permeando nuestra comunicación y sociabilidad; ¿será posible que estos medios tecnológicos influyan en la soledad de las personas? Ya influyen pues se busca compañía que no se tiene en el mundo offline, sin embargo, ¿podemos sentirnos acompañados todo el tiempo por un ser virtual sin esperar un contacto físico?

Puede que en un futuro se modifique nuestra concepción de la presencia física y suceda algo parecido como lo visto en las películas de George Lucas (Star Wars), los hologramas serán empleados para la comunicación y convivencia, y no sé, a lo mejor hasta de compañía en este mundo capitalista, urbano donde el tiempo se "siente" que pasa "volando" y los avances tecnológicos que siguen en constante transformación se acoplan a nuestra vida social y necesidades afectivas.

Finalmente, al realizar esta investigación pude darme cuenta de dos elementos que no tenía contemplados, desde comprender que la idea del amor construida a través de nuestras interacciones cotidianas permea la forma de navegar por Facebook, así como la participación de la presencia física como parte del proceso del noviazgo y que sin éste, no se mantiene. 


\section{REFERENCIAS}

Arnheim, R. (1971). El pensamiento visual. Buenos Aires: EUDEBA.

Andrade, F. et al. (2015). Ventajas y desventajas de las redes sociales en relaciones de pareja. Proyecto de investigación. Universidad Pedagógica Nacional "Francisco Morazán". Honduras.

Barrios, A. \& Pinto, B. (2008). El concepto del amor en la pareja. Revista AJAYU, Vol. 6, No. 2, Pp. 144-164.

Bernal, P. et al. (2015). Jóvenes y uso de Facebook. EN: Implicancias en el imaginario de amor y en la proyección de un ideal de pareja. Tesis. Pontifica Universidad Católica de Valparaíso, Chile.

Blanco, M. (2014). Implicaciones del uso de las redes sociales en el aumento de la violencia de género en Adolescentes. Comunicación y Medios, No. 30, Pp. 124-141.

Bologne, J. C. (2017). Historia de la pareja. México: Fondo de Cultura Económica.

Bourdieu, P. (2003). El oficio del científico. Ciencia de la ciencia y reflexividad. Barcelona: Editorial Anagrama.

Brito, P. (2012). Análisis de contenido Cualitativo y Cuantitativo. Consultado el día 14 de agosto de 2019 desde https://metodologiaecs.wordpress.com/2012/05/20/analisis-decontenido-cualitativo-y-cuantitativo/

Cabrales, G. (2019). El cibersexo, fenómeno contemporáneo de la cultura en jóvenes universitarios. Tesis de maestría. Universidad de la Costa. Barranquilla, Colombia.

Carr, N. (2010). The shallows: What the Internet Is Doing to Our Brains. W. W. Norton \& Company. (Traducción en español: Superficiales, ¿Qué está haciendo Internet con nuestras vidas? México: Taurus, 2011).

Castellanos, C. (2015). Influencia de las redes sociales en la relación de pareja de estudiantes de la Universidad Rafael Landívar. Tesis. Universidad Rafael Landívar, Guatemala. 
Chaves, M. (2017). Las redes sociales acaparan el uso de los celulares. La República. Consultado el día 29 de junio de 2019 desde https://www.larepublica.co/interneteconomy/las-redes-sociales-acaparan-el-uso-de-los-celulares-2473131

Checcori, A. et al. (2017). Fenómeno del sexting en adolescentes mujeres: Distrito de Cerro Colorado 2017. Tesis. Universidad Nacional de San Agustín, Arequipa, Perú.

Christakis, N. \& Fowler, J. H (2010). Social Network Sensors for Early Detection of Contagious Outbreaks. (Traducción en español: Conectados. México: Taurus, pp. 2010).

Cornejo, M. \& Tapia, M.L. (2011). Redes sociales y relaciones interpersonales en internet. Fundamentos en Humanidades, Vol. XII, No. 24, Pp. 219-229.

Corzo, C. \& Arteaga, L. (2018). Antecedentes históricos de las relaciones amorosas en la adolescencia y los problemas psicológicos que se generan durante estas (capítulo uno). ConCiencia Boletín Científico de la Escuela Preparatoria No. 3, Vol. 5, No. 9. Consultado el día 21 de septiembre de 2019 desde https://www.uaeh.edu.mx/scige/boletin/prepa3/n9/p1.html

Diccionario de la Lengua Española, (2019). Ligue. Consultado el día 28 de mayo de 2019 desde https://dle.rae.es/?id=NJ1Yfv6

The Economic, (2018). Modern Love: Online Dating. The Economic. Consultado el día 09 de octubre de 2018 desde https://www.economist.com/leaders/2018/08/18/modernlove?cid1=cust/ednew/n/bl/n/2018/08/16n/owned/n/n/nwl/n/n/la/144433/n

El Economista, (2018). 7 datos sobre los usuarios de internet en México en el 2017. Consultado el día 17 de agosto de 2018 desde https://www.eleconomista.com.mx/empresas/7-datos-sobre-los-usuarios-de-internet-enMexico-en-el-2017-20170518-0161.html

Erizos, (2018). Choche bajó del cielo para empaparnos de amor en forma de meme. Consultado el día 30 de junio de 2019 desde https://erizos.mx/memes/memes-de-choche-debronco/

Espinoza, K. \& Rojas, K. (2015). Establecimiento de Relaciones Amorosas por medio de la red social Facebook en una población joven. Tesis. Ciudad Universitaria Rodrigo Facio, San José, Costa Rica. 
Estébanez, I. (2015). El amor romántico ¿nuevos modelos? Consultado el día 12 de julio de 2019 desde http://minoviomecontrola.com/wp-content/uploads/2015/05/Amorrom\%C3\%A1ntico.-Nuevos-modelos.-Ianire-Est\%C3\%A9banez.pdf

Esteinou, R. (2009). Las relaciones de pareja en el México moderno. Revista Casa abierta al tiempo, No. 26, Pp. 65-75.

Esteinou R. (2017). Intimidad y amor romántico entre 1900 y 1950 en México. Discursos y normas. Cuicuilco Revista de Ciencias Antropológicas, No. 68, Pp. 35-57.

Excelsior, (2018). México, cuarto lugar a nivel mundial en uso de redes sociales. Consultado el día 1 de julio de 2019 desde https://www.excelsior.com.mx/hacker/2018/01/18/1214650

Expansión, (2011). Japoneses inventan una máquina para besar a través de internet. Consultado el día 2 de julio de 2019 desde https://expansion.mx/historiasextraordinarias/2011/05/05/japoneses-inventan-una-maquina-para-besar-a-traves-deinternet

Fernández, D. (2017). Entendiendo las relaciones de pareja en la era Tinder: análisis cualitativo y propuestas educativas. Tesis. Universidad de Oviedo, Facultad de Formación del Profesorado y Educación.

Fernández, P. (1994). La Psicología colectiva un fin de siglo más tarde. Barcelona: Anthropos.

Fernández, P. (2000). La afectividad colectiva. México: Taurus.

Fernández, P. (2001). La estructura mítica del pensamiento social. Athenea Digital, No. 0, Pp. 11-30.

Fernández, P. (2004). La sociedad mental. Barcelona: Anthropos.

Finkel, E. et al. (2014). The suffocation of marriage: climbing mount maslow without enough oxygen. Psychological Inquiry, No. 25, Pp. 1-41.

Fuentes, C. (2010). Algunas reflexiones sobre la transformación de la subjetividad en los jóvenes por el uso masivo de la tecnología. En Liévano, M. (2010). Bifurcaciones de la subjetividad. México: Tendencias. 
Gallardo, E. (2014). Utilización del programa de análisis cualitativo ATLAS. Ti, para gestionar y analizar datos. Consultado el día 2 de julio de 2019 desde https://atlasti.com/2014/06/12/utilizacion-del-programa-de-analisis-cualitativo-atlas-ti-paragestionar-y-analizar-datos/

García, A. \& Sabido, O. (2017). El estudio sociológico del amor corporeizado: la construcción de un objeto de estudio entrelazando teorías y niveles analíticos. Estudios Sociológicos $X X X V$, No. 105, Pp. 653-675.

García, E. \& Manzano, J. (2010). "Procedimientos metodológicos básicos y habilidades del investigador en el contexto de la teoría fundamentada", En Nateras, A. y De Alba, M. (2010) (coordinadores) Aproximaciones cualitativas a problemas sociales. Iztapalapa. Revista de Ciencias Sociales y Humanidades. México: Nueva época, Año 31, No. 69, Pp. 17-39.

García, L. \& Enciso, R. (2014). Influencia del Facebook en la relación de pareja. Revista EDUCATECONCIENCIA, Vol. 4, No. 4, Pp. 181-191.

Gaytan, P. (2009). Del piropo al desencanto: un estudio sociológico. Colección Sociología Serie Estudios. México: Biblioteca de Ciencias Sociales y Humanidades, Universidad Autónoma Metropolitana, Azcapotzalco.

Giddens, A, (1995). La transformación de la intimidad: sexualidad, amor y erotismo en las sociedades modernas, Madrid: Cátedra.

Gil-Juárez, A. (2002). Aproximación a una teoría de la afectividad. Athenea Digital, No. 1.

Gil-Juárez, A. (2007). “Nuevas tecnologías de relación” en Martínez, J. (coord.) (2007). Perspectivas y retrospectivas de la Psicología Social en los albores del Siglo XXI, Madrid: Editorial Biblioteca Nueva, Pp. 139-144.

Gómez, Y. (2006). La mujer, la coquetería y la moda en la obra de Georg Simmel. La Colmena, No. 51-52, Pp. 67-74. Consultado el día 27 de mayo de 2019 desde http://web.uaemex.mx/plin/colmena/Colmena\%2051/Aguijon/Yudmila.html

Gordo, A. (Coord.) (2006). Jóvenes y cultura Messenger. Tecnologías de la información y la comunicación en la sociedad interactiva. Madrid: INJUVE. 
Gurevich, A. (2016). El tiempo todo en Facebook. Aposta Revista de Ciencias Sociales, No. 69. Pp. 217-238.

Harré, R. (1982). El ser social. Una teoría para la psicología social. Madrid: Alianza Editorial.

Hofstatter, P. (1966). Introducción a la Psicología Social. Barcelona: Luis Miracle

Illouz, E. (2007). Intimidades congeladas: las emociones en el capitalismo. Madrid: Katz.

Instituto Nacional de Estadística y Geografía, (2017). Estadísticas a propósito del... día mundial de internet (17 de mayo). Consultado el día 29 de abril de 2018 desde http://www.inegi.org.mx/saladeprensa/aproposito/2017/internet2017_Nal.pdf

Islas, O. \& Benassini, C. (2005). Internet, columna vertebral de la sociedad de la información, México: Porrúa.

Lakoff, G. \& Jonhson, M. (1998). Metáforas de la vida cotidiana. España: Catedra.

Larocca, N. (2018). México: el 80\% de los usuarios móviles tienen un Smartphone. $\begin{array}{lllllll}\text { Consultado el } & 30 & \text { de } & \text { junio } & \text { desde }\end{array}$ https://www.telesemana.com/blog/2018/02/21/mexico-el-80-de-los-usuarios-movilestienen-un-smartphone/

Lasén. A. (2012). “Autofotos. Subjetividades y Medios Sociales”, en García-Canclini. N. \& Cruces, F. (Eds.) (2012). Jóvenes, culturas urbanas y redes digitales. Prácticas emergentes en las artes, el campo editorial y la música. Madrid: Ariel, Pp. 243-262.

Lasén, A. \& Puente, H. (2016). La cultura digital. Tecnologías sociales de la comunicación. Barcelona: UOC.

Malagón, L. et al. (2014). Influencia del Facebook en el mantenimiento de las relaciones de pareja en estudiantes de la Universidad Piloto de Colombia. Tesis. Colombia.

Márquez, I. (2015). La ciberpantalla; y La pantalla móvil. En: Una genealogía de la pantalla. Del cine al teléfono móvil. Barcelona: Anagrama, Pp. 171-235. 
Maxmovil, (2018). Cómo mejorar la seguridad y privacidad en Facebook. Consultado el día 20 de julio de 2019 desde https://www.maxmovil.com/blog/consejos/como-mejorar-laseguridad-y-privacidad-en-facebook/

Mead, G. (1973). Espíritu, Persona y Sociedad: Desde el punto de vista del Conductismo Social. Barcelona: Paidós.

Mediaclick, (2018). ¿Cuál es la edad de los usuarios de las redes sociales? Consultado el día 17 de agosto de 2018 desde https://www.mediaclick.es/blog/cual-es-la-edad-de-losusuarios-de-las-redes-sociales/

Miller, D. et al. (2018). Why we post? Consultado el día 30 de abril de 2018 desde http://www.ucl.ac.uk/why-we-post/spanish

Ojeda R. y Avilés, M. (2018). Nuevo Diccionario amoroso. Consultado el día 9 de noviembre de 2019 desde https://cultura.nexos.com.mx/?p=15021

Olías, L. (2015). La idea del amor romántico entre los jóvenes disfraza de cariño la violencia machista. Consultado el día 20 de julio de 2019 desde https://www.eldiario.es/sociedad/control-pareja-violencia-jovenes-

espanoles_0_350665513.html

Ong, W. (2016). Oralidad y escritura. Tecnologías de la palabra. México: Fondo de Cultura.

Pascual, A. (2016). Sobre el mito del amor romántico. Amores cinematográficos y educación. Dedica. Revista de Educação e Humanidades, No. 10, Pp. 63-78.

Pedroza, M. (2017). ¿Qué significa que una fotografía no tenga filtro? Consultado el día 1 de julio de 2019 desde https://www.sopitas.com/noticias/opinion/confiltro/

Piccini, M. (1996). Acerca de la comunicación en las grandes ciudades. Revista Perfiles latinoamericanos, No. 9, pp. 25-46.

Portalatín, B. (2013). Las parejas a distancia crean vínculos más estrechos. El mundo. $\begin{array}{llllllll}\text { Consultado el día } & 28 \text { de } & \text { junio } & \text { de } & \end{array}$ https://www.elmundo.es/elmundosalud/2013/07/19/noticias/1374221050.html 
Puma, H. (2012). La atracción en la elección de pareja. Revista Científica de Ciencias de la Salud, Vol. 5, No. 1, Pp. 50-60.

Quintana, G. (2016). Motivos para el uso de Instagram en los adolescentes. Proyecto de investigación. Universidad de Cantabria, Santander, España.

Real Academia Española, (2019). Real Academia Española Diccionario. Consultado el día 7 de agosto de 2019 desde http://lema.rae.es/drae2001/srv/search?id=ttIyhpiT7DXX2p26VbYf

Reyes, V. (2017). Móvil-izando. Significado del teléfono móvil. CuidArte El Arte del Cuidado, Vol. 6, No. 12, Pp. 30-39.

Rizo, M. (2011). De personas, rituales y máscaras. Erving Goffman y sus aportes a la comunicación interpersonal. Quórum Académico, Vol. 8, No. 15, Pp. 78-94

Roca, J. (2011). Amores glocales, noviazgos transnacionales. La búsqueda virtual de pareja mixta por parte de hombres españoles. Revista de Antropología Social, Vol. 20, Pp. 263-292 Rodríguez-Brioso, M. (2004). Las relaciones de pareja en la juventud española: entre la tradición y las preferencias individuales. Revista de Estudios de Juventud, No. 67, Pp. 71-84. Rodríguez, G. (2017). Una breve historia de las redes sociales. Hootsuite. Consultado el día 29 de junio de 2019 desde https://blog.hootsuite.com/es/breve-historia-de-las-redes-sociales/ Rodríguez, G. (2001). "Perdiendo los estribos". Emociones y relaciones de poder en el cortejo. Desacatos, No. 6, Pp. 35-62.

Rodríguez, T. (2012). El amor en las ciencias sociales. 4 visiones teóricas. Culturales, No. 15, Vol. 8, Pp. 155-180.

Rodríguez, T. \& Rodríguez, Z. (2016). El amor y las nuevas tecnologías: experiencias de comunicación y conflicto. Comunicación y Sociedad, No. 25, Pp. 15-41.

Sabater, C. (2014). La vida privada en la sociedad digital. La exposición pública de los jóvenes en internet. Revista de Ciencias Sociales, No. 61, Pp. 1-32.

Sabido, O. (2013). Los retos del cuerpo en la investigación sociológica. Una reflexión teórica-metodológica. En Aguilar, M. y Soto, P. (Coordinadores) (2013). Cuerpos, espacios 
y emociones: aproximaciones desde las ciencias sociales, México: Miguel Ángel Porrúa/Universidad Autónoma Metropolitana-Iztapalapa, Pp. 19-54.

Salmerón, M.A. et al. (2013). Acoso a través de Internet. Revista Pediatría Integral, Vol. 17, No. 7, Pp. 529-533.

Sánchez, J.A. (2015). “Cultura visual digital y campos de acción en redes sociales”. En Winocur, R \& Martínez, J. (2015). Redes Sociodigitales en México. México: CONACULTA/FCE.

Santa, P. (2017). ¿Te han pedido tu pack? ¿Qué es el pack? Consultado el día 2 de julio de 2019 desde https:/www.sdpnoticias.com/nacional/2017/05/25/te-han-pedido-tu-pack-quees-el-pack

Scandroglio, et al. (2008). La teoría de la Identidad Social: una síntesis de sus fundamentos, evidencias y controversias. Revista Psicothema, Vol. 20, No. 1, Pp. 80-89.

Serrano, O. (2017). Gifs y redes sociales: ¿una nueva forma de comunicar? Consultado el día 29 de junio de 2019 desde https://agenciacomma.com/diseno-y-creatividad/gifs-redessociales/

Simmel, G. (1908). Soziologie Untersuchungen über die Formen der Vergesellschaftung. Leipzig: Duncker \& Humblot (Traducción en español: Sociología: estudios sobre las formas de socialización, México: Fondo de Cultura, 2014).

Steve, O. (2018). Internet en México es menos democrático de lo que imaginábamos; menos de 2 de cada 10 personas provienen de zonas rurales. Consultado el día 30 de junio de 2019 desde https://www.xataka.com.mx/telecomunicaciones/internet-en-mexico-es-menosdemocratico-de-lo-que-imaginabamos-menos-de-2-de-cada-10-personas-provienen-dezonas-rurales

Strauss, A. L., \& Corbin, J. M. (1990). Basics of qualitative research: Grounded theory procedures and techniques (p. 270). Newbury Park, CA: Sage Publications

Tenorio, N. (2010). ¿Qué tan modernos somos? El amor y la relación de pareja en el México contemporáneo. Ciencias, No. 99, pp. 38-49. 
Toledo, V. (2018). La multisignificación de los emojis en entornos virtuales. Tesis de maestría, ITESO.

Torres, G. (2018). Júlia Bertran: El amor romántico es un modelo basado en la desigualdad de género. Consultado el día 24 de junio de 2019 desde https://www.lavanguardia.com/demoda/feminismo/20180110/433626966401/julia-bertran-entrevista-feminismo-amar-ytimar.html

We are social (2019). Digital 2019: Global Internet Use Accelerates. Consultado el día 7 de octubre de 2019 desde https://wearesocial.com/blog/2019/01/digital-2019-global-internetuse-accelerates

Winocur, R. (2015). "Prácticas tradicionales y emergentes de lectoescritura en jóvenes universitarios”. En García-Canclini, N. et al. (2015). Hacia una antropología de los lectores. México: Ediciones Culturales Paidós y Editorial Ariel. Pp. 243-278

Yarto, C. (2009). El teléfono celular y la construcción de la identidad. Revista Latinoamericana de Ciencias de la Comunicación, ALAIC, No. 11.

\section{Referencias de imágenes:}

Best Feo Memes, (2019). Feo memes. Consultado el día 6 de julio de 2019 desde https://me.me/t/feo?s=new\&since=0,c907caf918f241c6a3c3d34409e116f9

El Sol de México, (2018). No habrá agua pero sí ríos de memes. Consultado el día 6 de julio de 2019 desde https://www.elsoldemexico.com.mx/doble-via/virales/memes-corte-de-aguacdmx-edomex-df-no-hay-agua-pero-si-rios-de-memes-2529262.html

Puyol, J. (2016) ¿Qué son los “emojis”, o “emoticonos” y cómo están cambiando la comunicación? Consultado el día 6 de julio de 2019 desde https://confilegal.com/20160717que-son-los-emojis-emoticonos-comunicacion/ 


\section{ANEXOS}

\section{ANEXO 1}

Lista de emojis que se activan en Facebook

\begin{tabular}{|c|c|}
\hline (:) Feliz & | \\
\hline (:) Triste & $:-1: 1:[=1$ \\
\hline (4) Mostrando Lengua & $:-P: P:-P: P=P$ \\
\hline (:) Muy Feliz & $:-D: D=D$ \\
\hline (:) Asombrado & $: 0: 0:-0: 0$ \\
\hline ()) Guiño & ; \\
\hline (9) Gafas & 8-( 8) B-| B) \\
\hline Gafas de Sol & $8-|8| \mathrm{B}-|\mathrm{B}|$ \\
\hline (2) Enojado & $>: 1>:-1$ \\
\hline (:) Inseguro & $: /:-/: 1:-1$ \\
\hline (7) Llanto - Lloron & !' \\
\hline (3) Diablo - Demonio & $3:) 3:-1$ \\
\hline (:) Angel & $0: 10:-1$ \\
\hline (2) Beso & $:_{-*}^{*}$ \\
\hline Ocorazon & $<3$ \\
\hline (3) Feliz & ${ }^{n}{ }_{-}^{n}$ \\
\hline$\Theta$ Muy Feliz & - \\
\hline (9) Confundido & 0.00 .0 \\
\hline (3) Guiño & $>: 0>:-0>: 0>:-0$ \\
\hline () Pacman & $: v$ \\
\hline (20) Risa de Gato & $: 3$ \\
\hline :.: Asombrado & $: 1]$ \\
\hline C Putnam & :putnam: \\
\hline A Tiburon & $\left({ }^{n a n}\right)$ \\
\hline A Pinguino & $<(“)$ \\
\hline 4242 & $: 42:$ \\
\hline
\end{tabular}

Citado en: http://www.aeromental.com/2011/08/19/lista-completa-de-codigos-para-activarlos-emoticones-de-facebook/ 
ANEXO 2

\title{
Guía de entrevista
}

\section{Tema: Relaciones de Pareja a través de Facebook}

\section{Presentación:}

Mi nombre es Verónica Janette Castillo Bravo, soy estudiante de la Universidad Autónoma Metropolitana, Unidad Iztapalapa. Estoy realizando un estudio sobre relaciones de pareja que inician y se mantienen a través de Facebook, por lo que me interesa conocer tu experiencia respecto a esta vivencia. Recuerda que no hay respuestas correctas o incorrectas, y también cabe mencionar que la información proporcionada será confidencial y con fines únicamente de investigación, si deseas cambiar tu nombre por un seudónimo estás en toda la libertad (para mayor confidencialidad decidí no incluir las transcripciones, por lo que, solo se cuenta con los fragmentos expuestos en el análisis). Antes de comenzar necesito preguntarte si estás de acuerdo que nuestra conversación sea grabada, ya que es necesario para la reflexión de este estudio, bueno, a continuación te solicitaré algunos datos generales como:

\section{Datos personales:}

Edad:

Ocupación:

Creencia religiosa:

Lugar de residencia:

\section{Categorías:}

\author{
1.- Uso del Facebook \\ Indicadores: Uso cotidiano, Relación con otras redes sociales/ prácticas \\ sociales/significados
}

- ¿Cuáles son las redes sociales que más utilizas en tu vida cotidiana?

-¿Cómo creaste tu cuenta de Facebook?

¿¿Cuáles son los factores que consideras para agregar o mandar solicitud de amistad? 


\section{2.- Pensamiento Social: Relaciones de pareja}

Indicadores: Inicio, mantenimiento y final del noviazgo/prácticas sociales/significados

Posibles preguntas:

-Has tenido una relación de pareja/noviazgo a través de esta red social. (Platícame el inicio, el mantenimiento y el fin).

-¿Qué tomas en cuenta para iniciar una relación de pareja por Facebook?

-¿Cómo usas el Facebook para tu noviazgo?

-¿Qué piensas de las relaciones de pareja que estableces por medio de Facebook?

- ¿Has expresado con tus seres queridos que iniciaste una relación de pareja a través de Facebook? Platícame.

\section{3.- Lenguaje escrito, prácticas sociales y sobreentendidos}

Indicadores: Texto/ imágenes/fotografías/prácticas cotidianas/signos y significados/vida

$$
\text { privada/vida pública }
$$

Posibles preguntas:

-¿Cómo utilizas el Facebook para comunicarte con tu novia (o)?

-¿Usas el chat de Facebook (inbox) para conversar con tu pareja? Platícame.

-¿De qué conversan y qué tipo de contenido comparten?

-¿Qué información compartes de manera pública (comentarios, reacciones a las publicaciones, vídeos virales, etc.) con tu pareja?

-¿Qué tipo de imágenes (memes, noticias) comparten tú y tu pareja?

-¿Qué tipo de fotos compartes con tu pareja?

\section{4.- Afectividades Sociales}

Indicadores: Sentimientos/Signos y Significados

Posibles preguntas:

-¿Qué piensas de su relación?

-¿Para ti qué es el amor? 


\section{Participa en el proyecto de investigación: Relaciones de pareja a través de Facebook}

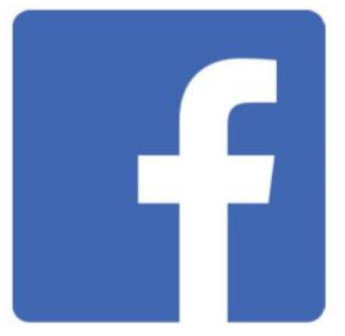

Si tú iniciaste o tuviste una relación de noviazgo (heterosexual) a través de Facebook, y tienes entre 18 a 40 años de edad, nos gustaría que pudieras contar tu historia en una entrevista y esto formará parte de este proyecto de investigación.

$\mathrm{Si}$ deseas participar manda un mensaje al correo electrónico: verojancasbra@gmail.com

Fecha límite para contactarnos hasta el 15 de marzo de 2019

El estudio es realizado por la Lic. Verónica J. Castillc estudiante de la maestría en Psicología Social de la Universidad Autónoma Metropolitana Unidad Iztapalapa. 


\section{ANEXO 4}

Las características generales de las mujeres entrevistadas son las siguientes:

\begin{tabular}{|c|l|l|l|}
\hline Participante & Edad & Ocupación & Tiempo de relación \\
\hline 1 & 25 & Estudiante & 2 semanas \\
\hline 2 & 27 & Empleada & 6 meses \\
\hline 3 & 43 & Comerciante & 4 meses \\
\hline 4 & 24 & Estudiante & 4 años \\
\hline 5 & 24 & Estudiante & 8 años \\
\hline 6 & 22 & Estudiante & 1 año, 6 meses \\
\hline
\end{tabular}

Cuadro 1. Características de las entrevistadas

Las características generales de los hombres entrevistados son:

\begin{tabular}{|c|l|l|l|}
\hline Participante & Edad & Ocupación & Tiempo de relación \\
\hline 1 & 21 & Empleado & 4 meses/ 8 meses \\
\hline 2 & 33 & Estudiante & 1 año/ 2 meses \\
\hline 3 & 30 & Empleado & 2 meses \\
\hline 4 & 29 & Empleado & 8 años \\
\hline
\end{tabular}

Cuadro 2. Características de los entrevistados 
ANEXO 5

\section{CODIFICACIÓN}

Tabla de Conceptos

\begin{tabular}{|c|c|c|c|}
\hline No. & Código & Definición & Ejemplo \\
\hline 1. & Agregar "amigos" & $\begin{array}{l}\text { Los factores que } \\
\text { consideran para aceptar o } \\
\text { enviar solicitudes de } \\
\text { amistad }\end{array}$ & $\begin{array}{l}\text { “(...) Pues yo, en lo personal, solo agrego } \\
\text { gente que conozco, que he visto en } \\
\text { persona, es la única forma en la que puedo } \\
\text { agregar, o que agrego o llego a agregar a } \\
\text { alguien...” } \\
\text { Participante 4, Mujer }\end{array}$ \\
\hline 2. & Amigos & $\begin{array}{l}\text { Pensamiento de sus } \\
\text { amigos respecto a la } \\
\text { relación de pareja que } \\
\text { establecieron }\end{array}$ & $\begin{array}{l}\text { “(...) el mismo grupito de amigos o de } \\
\text { gente que conoces te perjudicaba tu } \\
\text { relación "Felices los } 4 \text { ” y “¿cómo sabes?" } \\
\text { te metían dudas y pues yo no era de esos } \\
\text { pero poco a poco fui cayendo y como yo } \\
\text { padecía de depresión en cierto tiempo..." } \\
\text { Participante 4, Hombre }\end{array}$ \\
\hline 3. & Amor y Pareja & $\begin{array}{lll}\text { Concepción de } & \text { este } \\
\text { sentimiento } & & \\
\end{array}$ & $\begin{array}{c}\text { “(...) sería lealtad, fidelidad, comprensión, } \\
\text { sinceridad, confianza, comunicación y tal } \\
\text { vez podría ser esperanza, no, no esperanza } \\
\text { bueno sí esperanza de qué va a pasar al día } \\
\text { siguiente después de que estén juntos, } \\
\text { esperar...” } \\
\text { Participante } 1, \text { Mujer }\end{array}$ \\
\hline 4. & Atracción física & $\begin{array}{l}\text { Existe un gusto físico por } \\
\text { alguien a través de sus } \\
\text { fotos }\end{array}$ & $\begin{array}{l}\text { “(...) yo subí una foto, sí que decían pon } \\
\text { una foto solo de tu cara y así fue como } \\
\text { inicio, "ay, qué guapa” y yo luego busqué } \\
\text { a toda la gente que le dio like a la foto, en }\end{array}$ \\
\hline
\end{tabular}




\begin{tabular}{|c|c|c|c|}
\hline & & & $\begin{array}{l}\text { la foto que aparecía él dije “ay, qué guapo } \\
\text { está el señor" entonces le regresé “qué } \\
\text { guapo se ve usted en esa foto” y así fue } \\
\text { como inició todo.” } \\
\text { Participante 3, Mujer }\end{array}$ \\
\hline 5. & $\begin{array}{c}\text { Ausencia de Contacto } \\
\text { físico }\end{array}$ & $\begin{array}{l}\text { Cuando no se pudo } \\
\text { concretar el encuentro } \\
\text { físico }\end{array}$ & $\begin{array}{l}\text { “(...) y me empezó a fastidiar porque dije } \\
\text { "como que estoy descuidando mi negocio } \\
\text { y como que no le veo a esto caso" porque } \\
\text { dije "yo nunca voy a ir a Ecuador, él } \\
\text { nunca va a venir a México" dije "entonces } \\
\text { qué nos estamos haciendo tontos"y } \\
\text { entonces no, agarre y lo corte y dije "no, } \\
\text { sabes qué, no me parece"." } \\
\text { Participante } 3 \text {, Mujer }\end{array}$ \\
\hline 6. & Barajita & $\begin{array}{l}\text { Se le llama a la } \\
\text { presentación pública de } \\
\text { quién se es a partir de } \\
\text { fotos e información } \\
\text { personal como gustos } \\
\text { (Anteriormente, en la } \\
\text { página } 40 \text { se explicó } \\
\text { brevemente su definición) }\end{array}$ & $\begin{array}{l}\text { “(...) para estar ahí permanecer en el } \\
\text { grupo pues tienes que poner una foto tuya } \\
\text { e ir diciendo qué es lo que te gusta, qué es } \\
\text { lo que buscas, etc., ellas le llaman las } \\
\text { barajitas, "sube tu barajita si no te } \\
\text { sacamos”..." } \\
\text { Participante } 2, \text { Mujer }\end{array}$ \\
\hline 7. & Bloqueo & $\begin{array}{l}\text { Acción de bloquear a } \\
\text { alguien de Facebook o } \\
\text { WhatsApp }\end{array}$ & $\begin{array}{c}\text { “(...) ya no estaba al pendiente del celular } \\
\text { y lo que hizo esta persona fue bloquearme, } \\
\text { me bloqueó creo, o me eliminó e hizo otra } \\
\text { cuenta y bueno, ahí me ves llorando y } \\
\text { todas esas cuestiones y pues fue una } \\
\text { relación...” } \\
\text { Participante } 2, \text { Mujer }\end{array}$ \\
\hline
\end{tabular}




\begin{tabular}{|c|c|c|c|}
\hline 8. & Citas & $\begin{array}{l}\text { Las actividades realizadas } \\
\text { cuando se ven de manera } \\
\text { física }\end{array}$ & $\begin{array}{c}\text { “(..) me llevó a conocer el ángel, el } \\
\text { monumento a la Revolución, Museo de } \\
\text { Cera, creo que el Museo de Cera fue } \\
\text { después y así pues a varios lugares a } \\
\text { donde podía llevarme pero... ah, me llevó } \\
\text { a comer lo que más me encanta de allá son } \\
\text { los tacos de tripa entonces ese es un rito, } \\
\text { es de faul de que siempre que voy me } \\
\text { lleva a comer tacos de tripa eso no puede } \\
\text { faltar son como que ya las costumbres y } \\
\text { las reglas de nuestra relación de que si tú } \\
\text { vienes para acá, acá también él ya tienes } \\
\text { cosas, ya sabe a dónde vamos a ir “me } \\
\text { tienes que llevar a comer esto, me tienes } \\
\text { que llevar a este lugar y vamos a ir con tus } \\
\text { amigos acá y cosas así”...” } \\
\text { Participante } 5 \text {, Mujer }\end{array}$ \\
\hline 9. & Comentarios & $\begin{array}{l}\text { Lo dicho en una } \\
\text { publicación }\end{array}$ & $\begin{array}{l}\text { (...) te decía que la interacción que } \\
\text { tuvimos porque hay personas que conoces } \\
\text { por, que bueno comentas publicaciones en } \\
\text { ciertas paginas o ciertas imágenes, pero es } \\
\text { así como muy equis que así de que } \\
\text { divertido, y aquí era de seguir el hilo de la } \\
\text { conversación y dije ah mira, se puede } \\
\text { abordar el tema con esa persona, fue como } \\
\text { que el punto inicial, como si eso diferente } \\
\text { a otras publicaciones..." } \\
\text { Participante } 1, \text { Mujer }\end{array}$ \\
\hline 10. & $\begin{array}{l}\text { Comunicación } \\
\text { constante }\end{array}$ & $\begin{array}{l}\text { Prácticas llevadas a cabo } \\
\text { con mucha frecuencia }\end{array}$ & $\begin{array}{l}\text { “(...) se veía el interés, se veía, era muy } \\
\text { comunicativa, voy a hacer esto, voy a } \\
\text { hacer lo otro, así durante el día, voy a }\end{array}$ \\
\hline
\end{tabular}




\begin{tabular}{|c|c|c|c|}
\hline & & & $\begin{array}{l}\text { comer esto ¿no? mira que no sé qué, estoy } \\
\text { tomando mate, mi mamá te manda } \\
\text { saludos, que mi hermana, mis sobrinos } \\
\text { que yo les hable que tía esto...” } \\
\text { Participante 2, Hombre }\end{array}$ \\
\hline 11. & Confianza & $\begin{array}{l}\text { Conocer al otro a partir de } \\
\text { su interacción }\end{array}$ & $\begin{array}{l}\text { “(...) había confiado tanto en mí, me } \\
\text { contaba todo, todos sus problemas, todos } \\
\text { sus gustos, todos sus miedos, todo no sé } \\
\text { por qué como que la gente en la } \\
\text { madrugada sueltan todo, cañón pero como } \\
\text { que en la madrugada nos desahogamos } \\
\text { totalmente o estamos tan libres de no sé, } \\
\text { pero nos quedábamos tan tarde que la } \\
\text { plática en la noche es mejor, siempre } \\
\text { totalmente, funcionaba en la mañana pero } \\
\text { era como que se cortaba ¿no? porque decía } \\
\text { “ay, me voy a la escuela, voy a trabajar” } \\
\text { por eso nunca platicaba, eso lo aprendí } \\
\text { también que nunca era bueno platicar en } \\
\text { las tardes o en las mañanas siempre era } \\
\text { mejor en la noche, o sea me confiaban } \\
\text { totalmente todo que y empezábamos a } \\
\text { llevarnos tan bien que, créeme que no sé } \\
\text { cómo lograba eso que confiaran tan rápido } \\
\text { en mí, que luego ya empezáramos de } \\
\text { cariñosos, nos mandamos audios, } \\
\text { corazoncitos o cosas así...” } \\
\text { Participante } 3 \text {, Hombre }\end{array}$ \\
\hline 12. & Conocer a la familia & $\begin{array}{l}\text { En los encuentros físicos } \\
\text { es común visitar y }\end{array}$ & $\begin{array}{c}\text { “(...) bueno me invitó a su casa, me invitó } \\
\text { a comer, estuvimos platicando y todo } \\
\text { eso...” }\end{array}$ \\
\hline
\end{tabular}




\begin{tabular}{|c|c|c|c|}
\hline & & $\begin{array}{l}\text { presentar a la familia de } \\
\text { los involucrados }\end{array}$ & Participante 2, Mujer \\
\hline 13. & $\begin{array}{c}\text { Construcción social } \\
\text { del noviazgo en } \\
\text { Facebook }\end{array}$ & $\begin{array}{l}\text { Su concepción sobre las } \\
\text { relaciones de pareja que } \\
\text { se establecen a través de } \\
\text { Facebook }\end{array}$ & $\begin{array}{l}\text { “(...) que realmente no se conocen de } \\
\text { verdad hasta que ya conviven pues más } \\
\text { seguido y en otras situaciones no nada más } \\
\text { pues escribiéndose o mostrando nada más } \\
\text { lo que ellos quieren cuando nada más son } \\
\text { problemas, va más allá creo que el } \\
\text { enamoramiento o el amor en la pareja, sí } \\
\text { debe ser en persona, convivir realmente } \\
\text { ver realmente cómo es la persona, yo creo } \\
\text { esas relaciones a lo mejor sí cuando estás } \\
\text { hablando con ellos y no se conocen tú } \\
\text { crees que es bonito y todo eso pero ya } \\
\text { cuando se conocen ya te das cuenta de } \\
\text { cómo es en realidad...” } \\
\text { Participante } 6, \text { Mujer }\end{array}$ \\
\hline 14. & Contacto físico & $\begin{array}{l}\text { La impresión que } \\
\text { sintieron cuando la pareja } \\
\text { se vio por primera vez } \\
\text { físicamente }\end{array}$ & $\begin{array}{l}\text { “ubicaba de cara pero pues no sabía si sí } \\
\text { se iba a parecer de idéntico en vídeo, que } \\
\text { en persona y ya lo vi, y fue como de "ah, } \\
\text { ¡oh por dios!, ipor fin, después de tantos } \\
\text { años!, te tengo cerca, te puedo tocar y } \\
\text { abrazar"..." } \\
\text { Participante 4, Mujer }\end{array}$ \\
\hline 15. & Coqueteo & $\begin{array}{l}\text { Acciones que indican un } \\
\text { interés más allá de la } \\
\text { amistad }\end{array}$ & $\begin{array}{l}\text { “(...) Pues la verdad no me costó tanto } \\
\text { trabajo, lo único que hice se lo dije así } \\
\text { “pues vamos a ser novios, vamos a tener } \\
\text { una relación” pero sí ella era demasiado } \\
\text { evidente que a ella quería algo ¿no? } \\
\text { porque decía me mandaba fotos y así se } \\
\text { veía muy sexy y me decía “ ¿soy tu tipo o }\end{array}$ \\
\hline
\end{tabular}




\begin{tabular}{|c|c|c|c|}
\hline & & & $\begin{array}{l}\text { no soy tu tipo?" era muy evidente y ¿no? } \\
\text { entonces ya le dije "ah, pues vamos a ser } \\
\text { novios, vamos a andar” "no, pues sí, sí } \\
\text { quiero, quiero ser tu chica” ya de ahí } \\
\text { ya...” } \\
\text { Participante 2, Hombre }\end{array}$ \\
\hline 16. & Cuentas Falsas & $\begin{array}{l}\text { Perfil sospechoso, no hay } \\
\text { congruencia en los actos y } \\
\text { las fotos son muy } \\
\text { estéticas }\end{array}$ & $\begin{array}{l}\text { “(...) te digo y era obvio empezaban, se } \\
\text { lanzaban mucho por eso te digo que una } \\
\text { mujer nunca, a pesar de que sea una mujer } \\
\text { nunca se va a lanzar así, empezaban con } \\
\text { una frases muy absurdas los hombres no } \\
\text { saben fingir ser una mujer (...) y aparte } \\
\text { ponían fotos hasta... eran idiotas porque } \\
\text { ponían fotos de mujeres exuberantes y así } \\
\text { en bikini y decía (risas) "esta mujer jamás } \\
\text { me agregaría en la vida obviamente” y me } \\
\text { daba mucha risa porque muchos perfiles, } \\
\text { actualmente todavía me agregan perfiles } \\
\text { así pero actualmente yo ya no aceptó a } \\
\text { nadie yo sólo agregó...” } \\
\text { Participante } 3, \text { Hombre }\end{array}$ \\
\hline 17. & Cuenta reales & $\begin{array}{l}\text { Perfil que cuenta con } \\
\text { información "verídica" a } \\
\text { partir de fotos, personas y } \\
\text { lugares que visita }\end{array}$ & $\begin{array}{c}\text { “(...) yo siempre antes de agregar una } \\
\text { persona o algo así, siempre analizó todo el } \\
\text { perfil, fotos si realmente es esa persona si } \\
\text { no termino la interacción y la } \\
\text { comunicación, me voy distanciando...” } \\
\text { Participante } 2 \text {, Mujer }\end{array}$ \\
\hline 18. & Desconfianza & $\begin{array}{l}\text { Al ver el perfil no tiene } \\
\text { fotos o insinúa } \\
\text { interés } \quad \text { algún } \\
\end{array}$ & $\begin{array}{l}\text { “(...) ella pensaba que yo la iba a } \\
\text { secuestrar, ella me decía "ah, sí quiero } \\
\text { salir contigo pero me da miedo que me } \\
\text { secuestres” y le decía "no manches por }\end{array}$ \\
\hline
\end{tabular}




\begin{tabular}{|c|c|c|c|}
\hline & & $\begin{array}{ll}\text { comenzar } & \text { una } \\
\text { conversación } & \end{array}$ & $\begin{array}{l}\text { qué te voy a secuestrar" “ah, porque ni te } \\
\text { conozco, nos llevamos muy bien y pues sí } \\
\text { me da miedo salir contigo" y le decía "no, } \\
\text { pues le digo ve mi perfil, es como de una } \\
\text { persona muy real de fotos y entiendo su } \\
\text { desconfianza"..." } \\
\text { Participante } 3 \text {, Hombre }\end{array}$ \\
\hline 19. & Eliminación & $\begin{array}{l}\text { Se borra de amigos a la } \\
\text { persona que fue la pareja }\end{array}$ & $\begin{array}{l}\text { “(...) y todo eso aunque la segunda vez lo } \\
\text { elimine de Facebook, lo elimine de todos } \\
\text { lados..." } \\
\text { Participante 5, Mujer }\end{array}$ \\
\hline 20. & Emociones & $\begin{array}{l}\text { Sentimientos que se } \\
\text { experimentan en varias } \\
\text { etapas del noviazgo }\end{array}$ & $\begin{array}{l}\text { (...) tuve miedo también de hecho ya } \\
\text { después de que él vino ya dejé de grabar y } \\
\text { guardar todas las conversaciones porque } \\
\text { pues ya tenía confianza..." } \\
\text { Participante 5, Mujer }\end{array}$ \\
\hline 21. & Encuentros sexuales & $\begin{array}{l}\text { Verse de nuevo después } \\
\text { de dar por terminada la } \\
\text { relación. }\end{array}$ & $\begin{array}{l}\text { “(...) a los } 3 \text { meses las agregaba y de hecho } \\
\text { como con yo creo que con el } 50 \% \text { volvía a } \\
\text { salir y volvía ya no era cuando volvíamos a } \\
\text { salir ya no era como que algo tierno ya era } \\
\text { como algo más carnal ya casi era más como } \\
\text { sexo casual, nos volvemos a ver y pasaba, } \\
\text { dos veces y obviamente ya no había } \\
\text { necesidad de cortarlas ni nada porque ya } \\
\text { entendían que nada más nos veíamos por un } \\
\text { momento, y actualmente tengo a la mayoría } \\
\text { de ellas, debo tener a la gran mayoría...” } \\
\text { Participante } 3 \text {, Hombre }\end{array}$ \\
\hline 22. & Fin del noviazgo & $\begin{array}{l}\text { Se da por terminada la } \\
\text { relación }\end{array}$ & $\begin{array}{l}\text { “(...) ella todavía me dice gracias } \\
\text { necesitaba decirlo, yo creo que es como si } \\
\text { tú agarraras y dijeras no es que perdón y }\end{array}$ \\
\hline
\end{tabular}




\begin{tabular}{|c|c|c|c|}
\hline & & & $\begin{array}{c}\text { perdón y discúlpame no fue intencional y } \\
\text { que no sé qué, nunca te quise lastimar y } \\
\text { bla bla bla yo agarré y te digo “muy bien y } \\
\text { me voy"..." } \\
\text { Participante } 2, \text { Hombre }\end{array}$ \\
\hline 23. & Fotos juntos & $\begin{array}{l}\text { Tomar fotografías juntos } \\
\text { para después subirlas a } \\
\text { Facebook }\end{array}$ & $\begin{array}{l}\text { “(...) bueno ya nos dimos la oportunidad } \\
\text { de conocernos físicamente, pues yo subí } \\
\text { una foto, nos la tomamos precisamente en } \\
\text { el centro de Toluca y ya la publique, yo } \\
\text { siempre había sido muy reservada en } \\
\text { cuestión de anunciar mis relaciones de } \\
\text { noviazgo, pero esa vez como yo sí había, } \\
\text { sí me había enamorado digamos, este sí } \\
\text { publiqué la imagen, en la foto creo me } \\
\text { estaba dando un beso en la mejilla...” } \\
\text { Participante } 2, \text { Mujer }\end{array}$ \\
\hline 24. & Fotos públicas & $\begin{array}{l}\text { Son de perfil o son fotos } \\
\text { accesibles para otros } \\
\text { usuarios }\end{array}$ & $\begin{array}{l}\text { “(...) después de un directo metieron a } \\
\text { alguien, vi que metieron a alguien al grupo } \\
\text { y vi que era argentina porque ya me sé el } \\
\text { prefijo de Argentina es + 54, que también } \\
\text { tengo amigos y bla bla bla, y dije "ah pues } \\
\text { es de Argentina” no que Romina que } \\
\text { bienvenida dije "ah, qué Romina como } \\
\text { que es un nombre muy argentino" } \\
\text { entonces ya vi su perfil su foto de ella y } \\
\text { todo eso, me pareció bonita muy bonita, a } \\
\text { mí me gustan las argentinas, se me hacen } \\
\text { muy bonitas, muy atractivas y dije “Ah, } \\
\text { está bien bonita le voy a hablar"...” } \\
\text { Participante } 2 \text {, Hombre }\end{array}$ \\
\hline
\end{tabular}




\begin{tabular}{|c|c|c|c|}
\hline 25. & Grupos por Facebook & $\begin{array}{l}\text { Interacción a partir de } \\
\text { páginas enfocadas a los } \\
\text { gustos personales }\end{array}$ & $\begin{array}{l}\text { “(...) Yo trabajaba ahí donde te digo tenía } \\
16 \text { años cuando la conocí me mandó } \\
\text { solicitud, de hecho yo estaba en un grupo } \\
\text { de reggae, me fascina el reggae, me } \\
\text { encanta y subí mi foto, subí una foto que } \\
\text { tengo y ella le dio me gusta, en ese tiempo } \\
\text { que no existían las reacciones pues le dio } \\
\text { me gusta y pues me mando solitud y me } \\
\text { mandó un mensaje al principio pensé que } \\
\text { era una broma...” } \\
\text { Participante } 1, \text { Hombre }\end{array}$ \\
\hline 26. & Gustos & $\begin{array}{l}\text { Actividades, consumos } \\
\text { culturales en común }\end{array}$ & $\begin{array}{l}\text { “(...) bueno una noche fue esa noche } \\
\text { empezamos a platicar y dije “no, pues ya } \\
\text { me voy a dormir que no sé qué, si quieres } \\
\text { mañana seguimos platicando” “ah, sí”, } \\
\text { pues ya el otro día también le mandé unos } \\
\text { mensajes y todo eso, de hecho de eso si } \\
\text { tengo los audios, luego te los enseñó si } \\
\text { quieres y ya empezamos irnos conociendo, } \\
\text { conociendo, tenemos cosas afines, por } \\
\text { ejemplo, la música a mí me gusta el Rock, } \\
\text { me gusta el metal y a ella también, se } \\
\text { supone que tenemos la misma visión de } \\
\text { vida una más o menos similar, valores, } \\
\text { moral todo eso...” }\end{array}$ \\
\hline 27. & $\begin{array}{c}\text { Imágenes significantes } \\
\text { para ambos }\end{array}$ & $\begin{array}{l}\text { Se comparten imágenes } \\
\text { que muestran lo que } \\
\text { significa su relación }\end{array}$ & $\begin{array}{l}\text { "(...) recuerdo una imagen que estaba } \\
\text { muy graciosa porque era como un helado } \\
\text { y un foquito ahorrador, y que en medio era } \\
\text { un niño en forma de helado con foquito, } \\
\text { como un conito, dentro del helado con }\end{array}$ \\
\hline
\end{tabular}




\begin{tabular}{|c|c|c|c|}
\hline & & & $\begin{array}{l}\text { cabello o cabecita de foco, entonces así } \\
\text { como de algún futuro, ese era como } \\
\text { nuestra imagen que actualmente lo } \\
\text { llegamos a ver y me dice, "mira, esta } \\
\text { imagen me recuerda a ti", pero esa imagen } \\
\text { como que se impregno en nosotros dos fue } \\
\text { como un recuerdo de ambos o es un } \\
\text { recuerdo de ambo de que se, un día creo } \\
\text { que él me lo publicó, y me decía “Ah, } \\
\text { mira, nosotros en un futuro", que él era el } \\
\text { helado y yo era el foco y el foquito (risas) } \\
\text { pero este y así, o había otra imagen que } \\
\text { decía, nos publicábamos, nos } \\
\text { demostrábamos ese cariño por medio de } \\
\text { las imágenes, había otro que dice, fue hace } \\
\text { mucho tiempo "No sé tú, yo piénsalo", } \\
\text { Ah, no, era otra que decía este "No creas } \\
\text { que me emociono tanto con la relación } \\
\text { pero ya hasta le compre loncheritas a } \\
\text { nuestros niños" (risas), también ¿no? ya } \\
\text { nos comentábamos "ah, qué bonito" y } \\
\text { "pues sí, esperemos así durar mucho } \\
\text { tiempo". Y así se fue desarrollando por } \\
\text { medio de las imágenes y de la música, } \\
\text { demostrando ese mutuo cariño." } \\
\text { Participante } 2, \text { Mujer }\end{array}$ \\
\hline 28. & Información privada & $\begin{array}{l}\text { Toda esa información que } \\
\text { se comparte a través de } \\
\text { mensajes de texto, de voz, } \\
\text { por llamadas o } \\
\text { vídeollamadas }\end{array}$ & $\begin{array}{l}\text { “(...) teníamos nuestros momentos } \\
\text { cachondos, sexuales lo que sea, } \\
\text { mandarnos fotos, vídeos, audios, de todo } \\
\text { pero ya así sexual ¿no? también era parte } \\
\text { de, estaba padre ahí sí hubo más que con }\end{array}$ \\
\hline
\end{tabular}




\begin{tabular}{|c|c|c|c|}
\hline & & & $\begin{array}{c}\text { la otra, con la otra también tuvo cosillas } \\
\text { sexuales pero no tanto, sí me dio unas } \\
\text { fotos que..." } \\
\text { Participante } 2 \text {, Hombre }\end{array}$ \\
\hline 29. & Información pública & $\begin{array}{l}\text { Toda esa información que } \\
\text { se publica y es accesible } \\
\text { para otros usuarios }\end{array}$ & $\begin{array}{l}\text { “(...) por Facebook también, yo sí siempre } \\
\text { he puesto la relación, sí siempre la... } \\
\text { tengo la maña de enviar la relación o sea } \\
\text { “Zalva ha cambiado de soltero a tener una } \\
\text { relación con tal persona” y yo siempre le } \\
\text { enviaba a Facebook, siempre me he } \\
\text { considerado que he sido una persona como } \\
\text { que muy romántica y eso...” } \\
\text { Participante } 3 \text {, Hombre }\end{array}$ \\
\hline 30. & Inicio del noviazgo & $\begin{array}{l}\text { Comienzo de la relación } \\
\text { se puede definir cuando } \\
\text { uno de los dos, pregunta } \\
\text { ¿quieres ser mi } \\
\text { novia/novio? }\end{array}$ & $\begin{array}{l}\text { “(...) ya fue a los } 2 \text { días que nos } \\
\text { conocimos y todo ese rollo y dijo “ ¿sabes } \\
\text { qué? La verdad, no puedo dejar pasar así } \\
\text { algo ¿no? porque no había sentido con } \\
\text { alguien esto, esa conexión y así, ni } \\
\text { siquiera aquí en mi país” y la verdad pues } \\
\text { y le digo “¿no quieres ser mi novia?” y } \\
\text { dijo "sí” me dijo "que sí, sí quiero ser tu } \\
\text { novia” y ya empezamos a andar...” } \\
\text { Participante } 2, \text { Hombre }\end{array}$ \\
\hline 31. & Interacción & $\begin{array}{l}\text { Son las conversaciones } \\
\text { que se tienen previas al } \\
\text { inicio del noviazgo }\end{array}$ & $\begin{array}{l}\text { “(...) ir conociendo a una persona, } \\
\text { contando experiencias, anécdotas } \\
\text { chistosas, o mira "ay vi este meme", o } \\
\text { “esto y me acorde de ti”, pero en ese } \\
\text { entonces ya era para más pues para } \\
\text { entablar una conversación porque, porque } \\
\text { no teníamos ese vínculo, ay como en } \\
\text { noviembre o diciembre, era así, que }\end{array}$ \\
\hline
\end{tabular}




\begin{tabular}{|c|c|c|c|}
\hline & & & $\begin{array}{c}\text { sabíamos que teníamos en común, o que } \\
\text { cosas de Guadalajara." } \\
\text { Participante 1, mujer }\end{array}$ \\
\hline 32. & Ligar/Flirteo & $\begin{array}{l}\text { Intención de comenzar } \\
\text { una relación. }\end{array}$ & $\begin{array}{l}\text { “(...) dije "ah, esta chava está bonita la } \\
\text { voy a agregar” y me agregó y empezamos } \\
\text { a hablar y hablar y no teníamos nada en } \\
\text { común absolutamente nada en común y } \\
\text { pero empezamos a llevarnos tan divertido } \\
\text { que llegó un momento en el que me dijo } \\
\text { "ya estamos flirteando, verdad” y dije } \\
\text { "¿qué? “Ah, qué estamos ligando” sabía lo } \\
\text { que era filtrar...” } \\
\text { Participante } 3 \text {, Hombre }\end{array}$ \\
\hline 33. & Likes & $\begin{array}{l}\text { Dar "me gusta" a las } \\
\text { publicaciones }\end{array}$ & $\begin{array}{l}\text { “(...) cuando llegaron las imágenes yo } \\
\text { subía imágenes o agregaba chavas y } \\
\text { comentaba sus imágenes, y luego subía } \\
\text { imágenes que sabía que le iban a gustar a } \\
\text { ella y ella le daba "me gusta” y me daba } \\
\text { "me gusta” a las de ella y así que } \\
\text { empezaba a ver, era muy curioso porque } \\
\text { de repente veía que toda mi barra de } \\
\text { inicio, bueno mi barra de notificaciones } \\
\text { estaba llena de "me gusta” de ella, y era } \\
\text { obvio que ella quería algo conmigo a pesar } \\
\text { de que ni siquiera nos conociéramos nunca } \\
\text { hemos hablado en persona....” } \\
\text { Participante } 3 \text {, Hombre }\end{array}$ \\
\hline 34. & Lugares & Sitios que frecuentan & $\begin{array}{l}\text { “(...) esto fue muy curioso hubo una } \\
\text { pareja que, yo te digo que vivía en } \\
\text { Cuautitlán Izcalli, y ahora vivo en } \\
\text { Nezahualcóyotl y una vez empecé andar }\end{array}$ \\
\hline
\end{tabular}




\begin{tabular}{|c|c|c|c|}
\hline & & & $\begin{array}{l}\text { con una chava que vivía en Cuautitlán } \\
\text { Izcalli y pues yo nunca le había hablado, } \\
\text { para nada, nos agregamos y ya me dijo... } \\
\text { como agregué a mis amigos, me salían } \\
\text { sugerencias de personas que vivían ahí o } \\
\text { sea aparecía que yo vivía ahí en Cuautitlán } \\
\text { Izcalli todavía, me llegaban a salir } \\
\text { sugerencias que vivían ahí, o mis amigos } \\
\text { me contratan con ella, bueno, me pasaban } \\
\text { su Facebook...” } \\
\text { Participante } 3, \text { Hombre }\end{array}$ \\
\hline 35. & Madre & $\begin{array}{l}\text { Comentarios o acciones } \\
\text { de la madre }\end{array}$ & $\begin{array}{l}\text { “(...) mi mamá no le gustaba nuestra } \\
\text { relación, mi mamá siempre se ha } \\
\text { preocupado mucho por nosotros, mi mamá } \\
\text { es muy inteligente, se puede decir que yo } \\
\text { saque su don, pero no, mi mamá es muy } \\
\text { inteligente ella cuando dice “esa no te } \\
\text { queda, no te conviene”, tiene razón y yo } \\
\text { siento que fue ahí donde saque mi don de } \\
\text { saber realmente lo que quieren sacar las } \\
\text { personas...” } \\
\text { Participante } 1, \text { Hombre }\end{array}$ \\
\hline 36. & $\begin{array}{l}\text { Mantener contacto por } \\
\text { redes sociales }\end{array}$ & $\begin{array}{l}\text { Después de la ruptura aún } \\
\text { se mantienen } \\
\text { comunicados }\end{array}$ & $\begin{array}{l}\text { “(...) mi relación con ella la puedo dar por } \\
\text { terminada y hasta ahorita te digo que la } \\
\text { tengo en Facebook pero ya no platico con } \\
\text { ella, se podría decir como una conocida } \\
\text { nada más o sea después de tanto encanto } \\
\text { se volvió una conocida nada más, esa es la } \\
\text { realidad y la crueldad de las relaciones a } \\
\text { distancia...” } \\
\text { Participante } 1, \text { Hombre }\end{array}$ \\
\hline
\end{tabular}




\begin{tabular}{|c|c|c|c|}
\hline 37. & $\begin{array}{c}\text { Mantenimiento del } \\
\text { Noviazgo }\end{array}$ & $\begin{array}{l}\text { Actividades que realizan } \\
\text { para sostener la relación }\end{array}$ & $\begin{array}{c}\text { “(...) Él en ese entonces también estaba } \\
\text { estudiando y ya pasando yo lo conocí, } \\
\text { como por febrero precisamente, todavía } \\
\text { marzo, abril, ahí sobrellevábamos la } \\
\text { relación a distancia por mensajes, } \\
\text { llamadas, este Facebook...” } \\
\text { Participante 2, Mujer }\end{array}$ \\
\hline 38. & Metáforas & $\begin{array}{l}\text { Analogías que explican lo } \\
\text { que es el amor }\end{array}$ & $\begin{array}{l}\text { “(...) es un amor puro así como las mamás } \\
\text { o sea tienen un bebé que no sabe cómo va } \\
\text { a ser pero ya se enamoraron de él, van a } \\
\text { dar su vida así, o sea nace un amor de puro } \\
\text { o sea no sé es difícil, como los } \\
\text { manantiales ¿no? pues es agua pura así...” } \\
\text { Participante 4, Hombre }\end{array}$ \\
\hline 39. & Otro cotidiano & $\begin{array}{l}\text { Personas que influyen en } \\
\text { la construcción del } \\
\text { pensamiento de la } \\
\text { persona que establece un } \\
\text { noviazgo online }\end{array}$ & $\begin{array}{l}\text { (...) empezó los prejuicios de la gente y } \\
\text { más de mi parte, de mis papás y también } \\
\text { de ella porque pues en todos lados ¿no? } \\
\text { “¿cómo crees? Y no va a funcionar y } \\
\text { ¿cómo alguien de allá y no aquí cerca?” y } \\
\text { pues eso te incomoda porque pues o sea } \\
\text { “yo lo estoy intentando y no tú, qué te } \\
\text { importa así, no me estoy metiendo en tu } \\
\text { vida” y cuando me preguntaban “oye y } \\
\text { ¿tienes novia? Pues yo en cierta parte } \\
\text { dudaba decirle "sí, sí tengo novia pero no } \\
\text { es de aquî" } \\
\text { Participante } 4, \text { hombre }\end{array}$ \\
\hline 40. & Personas cercanas & $\begin{array}{l}\text { Personas que dan su } \\
\text { punto de vista respecto a } \\
\text { la relación, como los }\end{array}$ & $\begin{array}{l}\text { “(...) también mis papás me han apoyado } \\
\text { en eso, bueno, todavía no conocen las } \\
\text { demás personas, pero ahí alguna prima me } \\
\text { va a decir que, ay pues felices los } 4 \text { pero, }\end{array}$ \\
\hline
\end{tabular}




\begin{tabular}{|c|c|c|c|}
\hline & & $\begin{array}{l}\text { padres en general, los } \\
\text { hijos y los primos }\end{array}$ & $\begin{array}{c}\text { aun no conoce la historia ella, estoy segura } \\
\text { que va a decir eso." } \\
\text { Participante 1, Mujer }\end{array}$ \\
\hline 41. & Personas en común & $\begin{array}{l}\text { Son aquellos contactos } \\
\text { que llevan a conocer otras } \\
\text { personas }\end{array}$ & $\begin{array}{l}\text { “(...) Pues creo que sí, sí lo hacía seguido } \\
\text { como, de hecho mi novio que tengo } \\
\text { ahorita sí lo conocí así pero creo que sí es } \\
\text { muy diferente porque pues te digo, yo } \\
\text { aceptaba aunque no lo conociera pero pues } \\
\text { sí eran personas que tenían amigos en } \\
\text { común de la escuela o de mi familia o lo } \\
\text { que sea sí los aceptaba, y de hecho a mi } \\
\text { novio con el que estoy ahorita sí, la verdad } \\
\text { ni siquiera me acuerdo si me agregó o él } \\
\text { me agregó pero pues teníamos amigos en } \\
\text { común porque íbamos en la misma } \\
\text { escuela, solo que íbamos en turnos } \\
\text { diferentes y empezamos a hablar un } \\
\text { poco...” } \\
\text { Participante } 6, \text { Mujer }\end{array}$ \\
\hline 42. & Planes a futuro & $\begin{array}{l}\text { Actividades que esperan } \\
\text { hacer juntos }\end{array}$ & $\begin{array}{l}\text { “(...) no sé yo sentía que me iba a quedar } \\
\text { con ella, puedes creer la mentalidad que } \\
\text { tenía, yo sentía que me iba ajuntar con } \\
\text { ella, que me iba a casar con ella...” } \\
\text { Participante } 1, \text { Hombre }\end{array}$ \\
\hline 43. & Poca comunicación & $\begin{array}{l}\text { Actividades que indican } \\
\text { un desinterés }\end{array}$ & $\begin{array}{l}\text { “(...) cuando yo platicaba con ella ya la } \\
\text { sentía muy cortante, ya no sentía las } \\
\text { conversaciones como antes así, ya no las } \\
\text { sentí así, yo estaba listo para que ella me } \\
\text { dijera que termináramos, yo sabía que eso } \\
\text { iba a pasar...” } \\
\text { Participante } 1 \text {, Hombre }\end{array}$ \\
\hline
\end{tabular}




\begin{tabular}{|c|c|c|c|}
\hline 44. & Primer encuentro & $\begin{array}{l}\text { Actividades que realizan } \\
\text { la primera vez que se } \\
\text { encuentran de manera } \\
\text { física }\end{array}$ & $\begin{array}{l}\text { “(...) pasamos todo el día pues mi } \\
\text { hermana, mi sobrino, el novio de mi } \\
\text { hermana, él y yo, pasamos todo el día } \\
\text { juntos y este, y ya fuimos a museos, } \\
\text { visitamos la ciudad, todo el rollo, } \\
\text { llegamos a la casa...” } \\
\text { Participante 4, Mujer }\end{array}$ \\
\hline 45. & Regalos & $\begin{array}{l}\text { Obsequios o presentes } \\
\text { que se hacen durante la } \\
\text { primera cita }\end{array}$ & $\begin{array}{l}\text { “(...) fui a visitarlo hasta allá, te digo } \\
\text { estuvimos un ratito, convivimos él me } \\
\text { regaló un perrito de peluche de hecho } \\
\text { todavía lo tengo, me lo regaló...” } \\
\text { Participante 2, Mujer }\end{array}$ \\
\hline 46. & $\begin{array}{c}\text { Relaciones } \\
\text { Offline/Relaciones } \\
\text { Online }\end{array}$ & $\begin{array}{l}\text { Qué piensan de las } \\
\text { relaciones cotidianas que } \\
\text { se establecen de manera } \\
\text { física }\end{array}$ & $\begin{array}{l}\text { “(...) no qué flojera, no pues no, lo bonito } \\
\text { es estar con la persona, platicar así en } \\
\text { vivo, salir a pasear, salir al cine, a comer } \\
\text { una paleta de hielo, eso es lo bonito...” } \\
\text { Participante 3, Mujer }\end{array}$ \\
\hline 47. & Stalkeo & $\begin{array}{l}\text { Revisión de perfil para } \\
\text { saber de quién se trata }\end{array}$ & $\begin{array}{l}\text { “(...) yo siempre antes de agregar una } \\
\text { persona o algo así, siempre analizó todo el } \\
\text { perfil, fotos si realmente es esa persona si } \\
\text { no termino la interacción y la } \\
\text { comunicación, me voy distanciando...” } \\
\text { Participante 2, Mujer }\end{array}$ \\
\hline 48. & $\begin{array}{c}\text { Vinculación con otras } \\
\text { redes }\end{array}$ & $\begin{array}{l}\text { Uso de otras redes } \\
\text { sociales a parte de } \\
\text { Facebook }\end{array}$ & $\begin{array}{c}\text { "Una de ellas es Facebook, ahora } \\
\text { Instagram y WhatsApp puede ser que sea } \\
\text { una red social; son las } 3 \text { que más ahora } \\
\text { utilizo." } \\
\text { Participante 2, Hombre }\end{array}$ \\
\hline 49. & Vistos & $\begin{array}{l}\text { Marcar como leído el } \\
\text { mensaje sin contestar }\end{array}$ & $\begin{array}{l}\text { “(...) le mandé mensaje "oye fui una } \\
\text { entrevista, ¿qué crees? que esto mi amor } \\
\text { me fue tal y tal” me dejaba en visto, }\end{array}$ \\
\hline
\end{tabular}




\begin{tabular}{|c|c|c|c|}
\hline & & & $\begin{array}{l}\text { entonces yo le empezaba a insistir “¿estás } \\
\text { ahí, Romina estás ahí?” le insistía...” } \\
\text { Participante 2, Hombre }\end{array}$ \\
\hline 50. & WhatsApp & $\begin{array}{l}\text { El uso de esta red social } \\
\text { para las conversaciones } \\
\text { cotidianas }\end{array}$ & $\begin{array}{l}\text { “(...) A lo mejor ya platicas en privado en } \\
\text { el chat, bueno en el WhatsApp y ya de ahí, } \\
\text { comienzas a platicar bien, bien, nos } \\
\text { llevamos bien puntos de vista de la visión } \\
\text { no sé de la vida, del trabajo, de todo lo que } \\
\text { sea ¿no? como saber de la persona, dónde } \\
\text { vive, las costumbres, como que sí un } \\
\text { poquito enfocado en el turismo y ese rollo } \\
\text { porque a mí me gusta también por eso } \\
\text { creo que también como que agregue a otra } \\
\text { gente para saber culturalmente hablando; } \\
\text { entonces en eso ya los agrego y de ahí nos } \\
\text { empezamos a llevar bien y ya, pasamos a } \\
\text { ser amigos, también he tenido novias.” } \\
\text { Participante } 2, \text { Hombre }\end{array}$ \\
\hline
\end{tabular}




\section{ANEXO 6}

\begin{tabular}{|c|c|c|c|c|c|}
\hline Nombre & Fundame... & Densidad & Nombre & Fundame... & Densidad \\
\hline " Agregar "Amigos" & 27 & 5 & $2 \%$ Gustos & 17 & 1 \\
\hline Amigos & 21 & 2 & 2. Imagenes/fotos significativas para ambos & 14 & 2 \\
\hline Amor y Pareja & 20 & 3 & W: Información privada (llamadas, mensajes, audios) & 96 & 3 \\
\hline 20. Atracción física & 14 & 1 & 2.: Información pública (publicaciones) & 82 & 1 \\
\hline 20 Ausencia de contacto físico & 12 & 1 & 2 Inicio del noviazgo & 116 & 2 \\
\hline Barajita & 4 & 1 & 2: Interacción & 31 & 4 \\
\hline 2x: Bloqueo & 8 & 2 & Ligar/Flirteo & 6 & 2 \\
\hline Citas & 31 & 1 & Likes & 12 & 1 \\
\hline Comentarios & 7 & 1 & Lugares & 4 & 2 \\
\hline 20 Comunicación constante & 14 & 2 & Madre & 19 & 2 \\
\hline 2 Confianza & 8 & 2 & Mantener contacto por redes sociales & 12 & 1 \\
\hline 20. Conocer a la familia & 11 & 1 & Mantenimiento del Noviazgo & 66 & 6 \\
\hline CONSTRUCCIÓN SOCIAL DEL NOVIAZGO EN FA... & 93 & 3 & 说: Metáforas & 9 & 1 \\
\hline Contacto físico & 3 & 1 & 2: Otro cotidiano & 88 & 6 \\
\hline 20queteo & 12 & 2 & 2.: Personas cercanas & 41 & 2 \\
\hline Cuentas falsas & 18 & 1 & Personas en común & 7 & 2 \\
\hline Cuentas reales & 2 & 2 & Planes a futuro & 21 & 1 \\
\hline 20 Desconfianza & 2 & 1 & * Poca comunicación & 11 & 4 \\
\hline W: Eliminación & 12 & 2 & Primer encuentro & 54 & 10 \\
\hline Emociones & 44 & 3 & Regalos & 4 & 1 \\
\hline Encuentros sexuales & 2 & 1 & Relaciones Offline/Relaciones Online & 26 & 3 \\
\hline Fin del Noviazgo & 87 & 6 & Stalkeo & 14 & 4 \\
\hline 20 Fotos juntos & 6 & 1 & Vinculación con otras Redes & 49 & 2 \\
\hline Fotos públicas & 15 & 4 & Vistos & 5 & 2 \\
\hline Grupos/páginas & 15 & 5 & Whatsapp & 19 & \\
\hline
\end{tabular}

Figura 1. Número de Densidad de cada Código

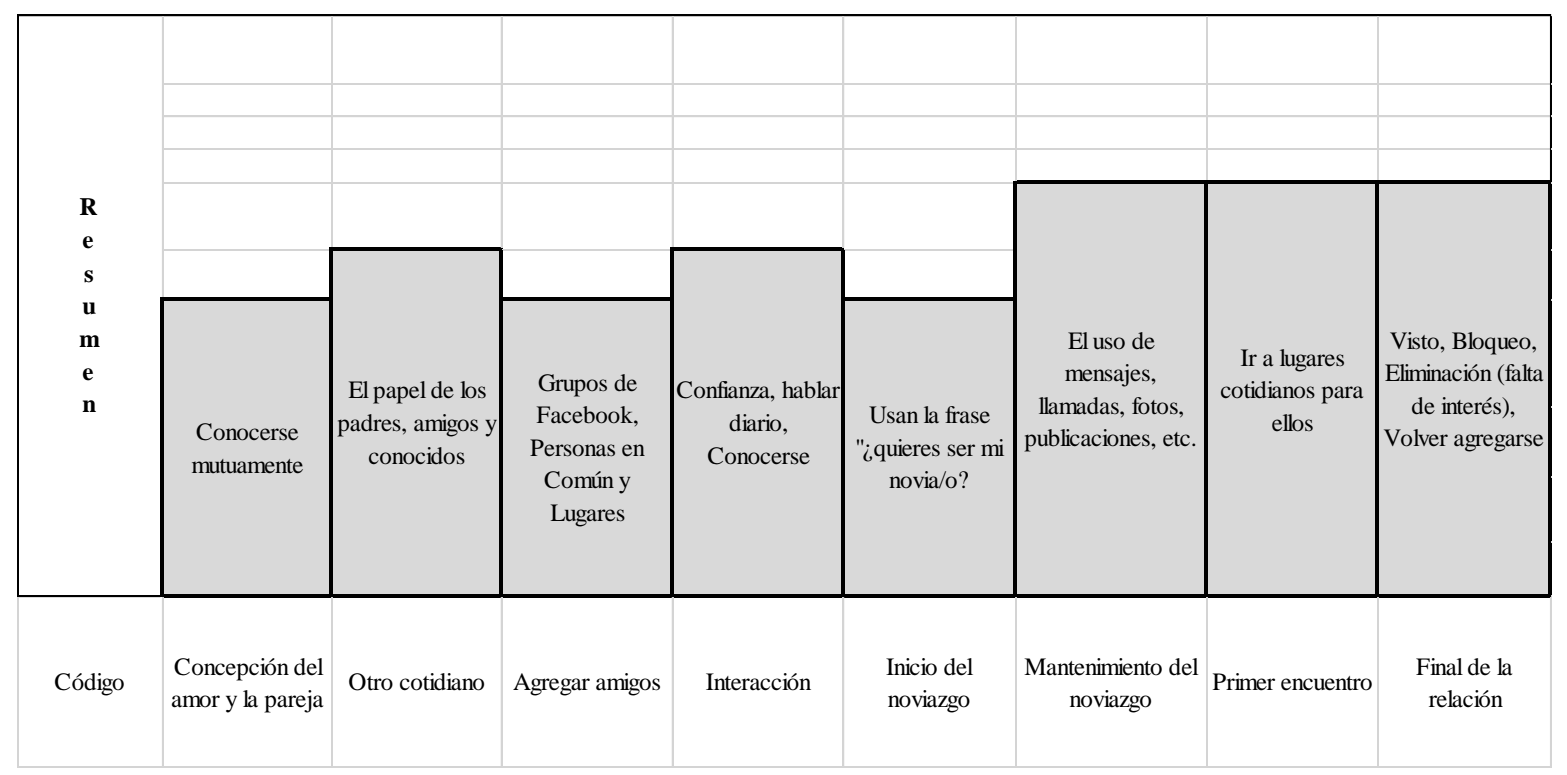

Figura 2. Códigos base en el proceso del noviazgo a través de Facebook 


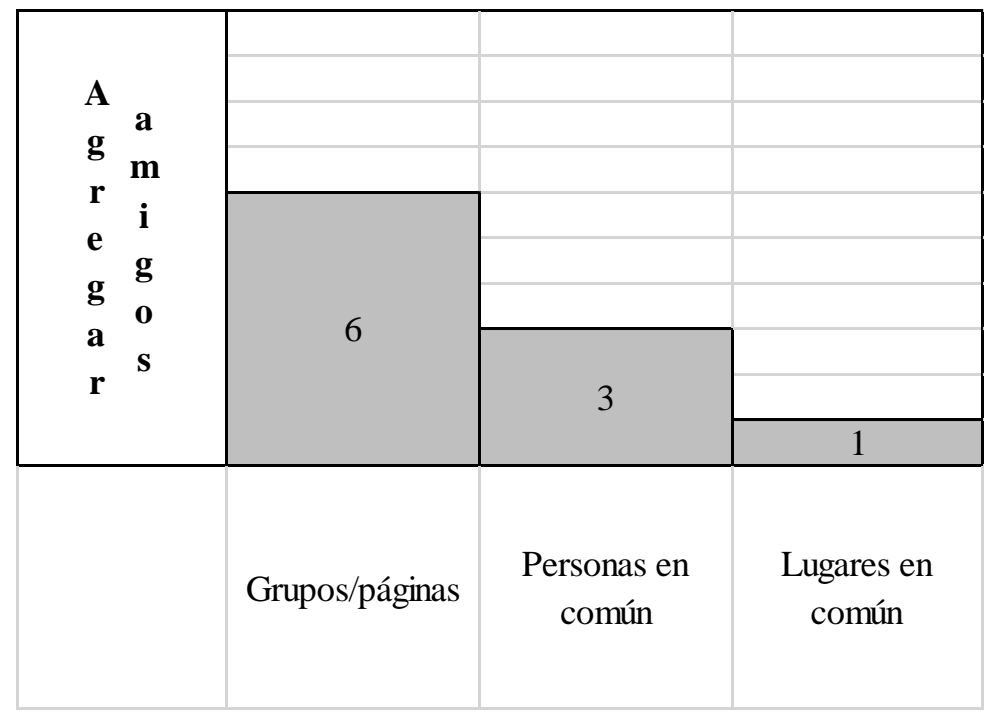

Figura 4. Maneras de agregar amigos
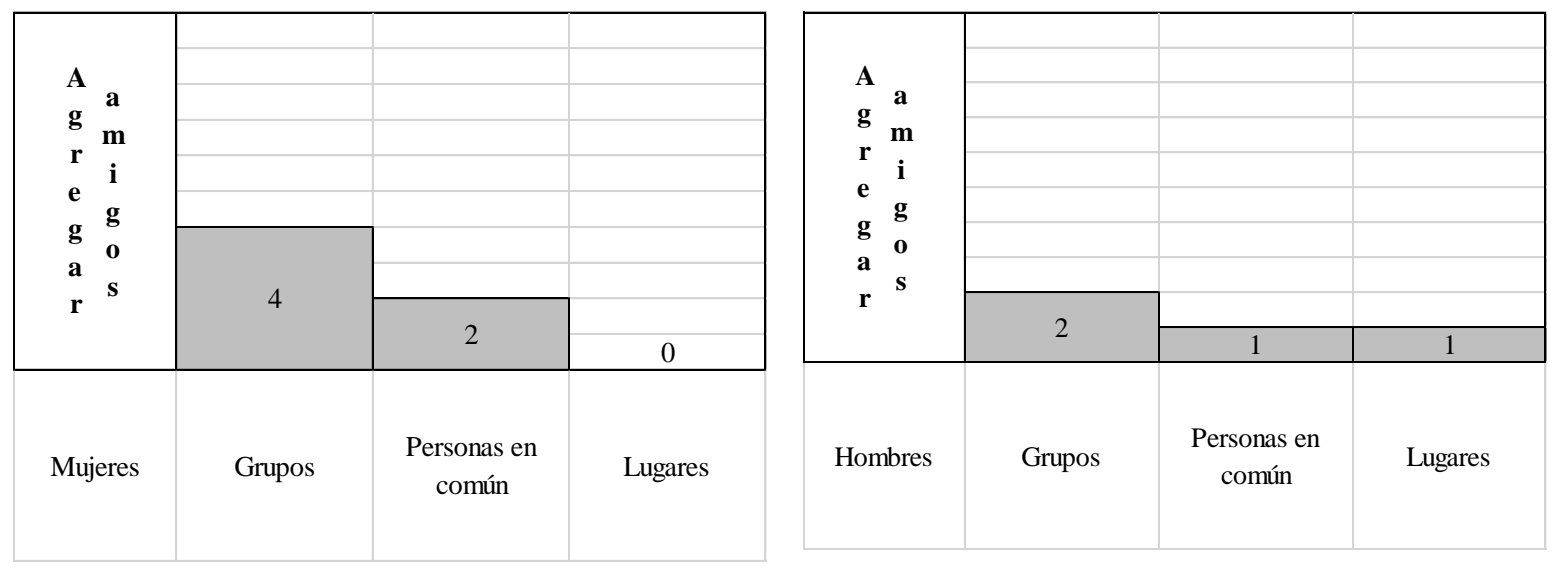

Figuras 5 y 6. Diferencia de género en agregar "amigos" en Facebook 

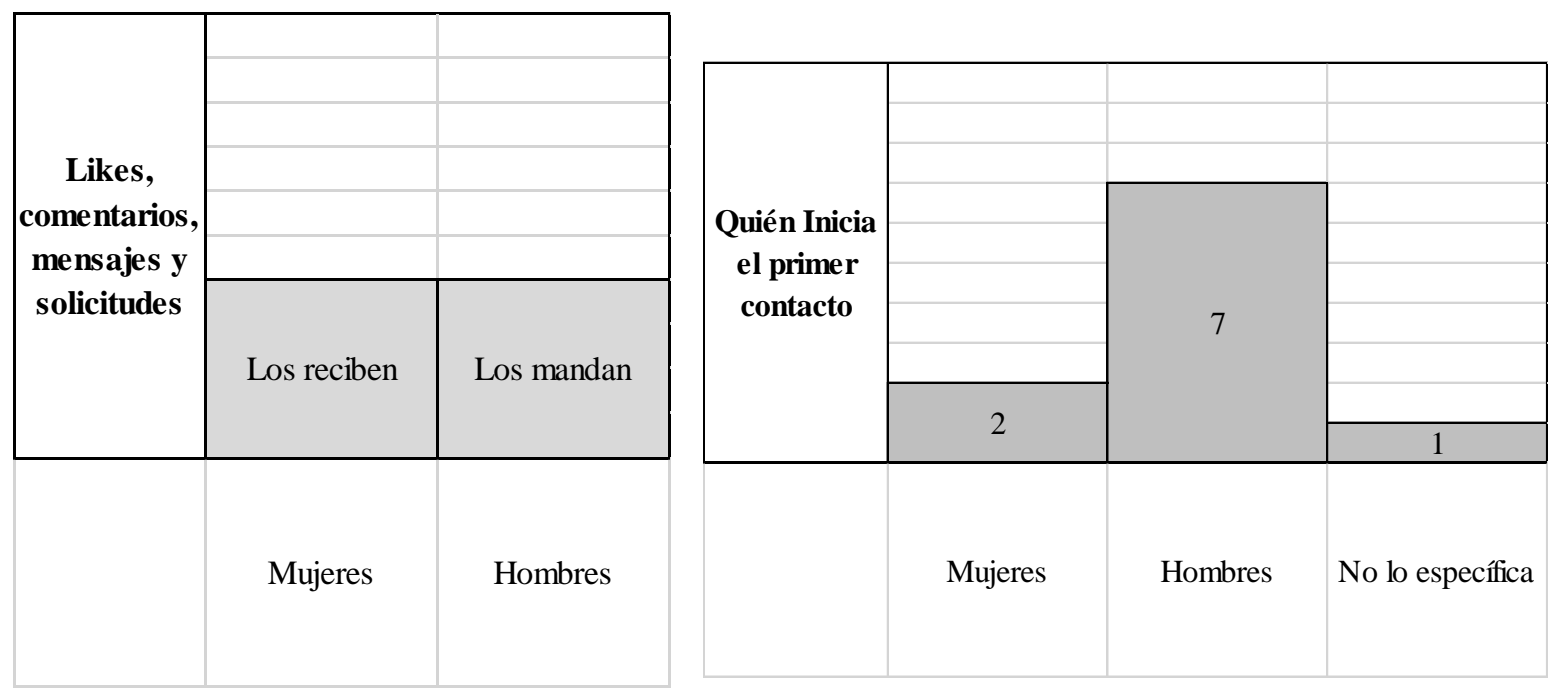

Figuras 7 y 8. Diferencia de género en el inicio de la interacción en Facebook

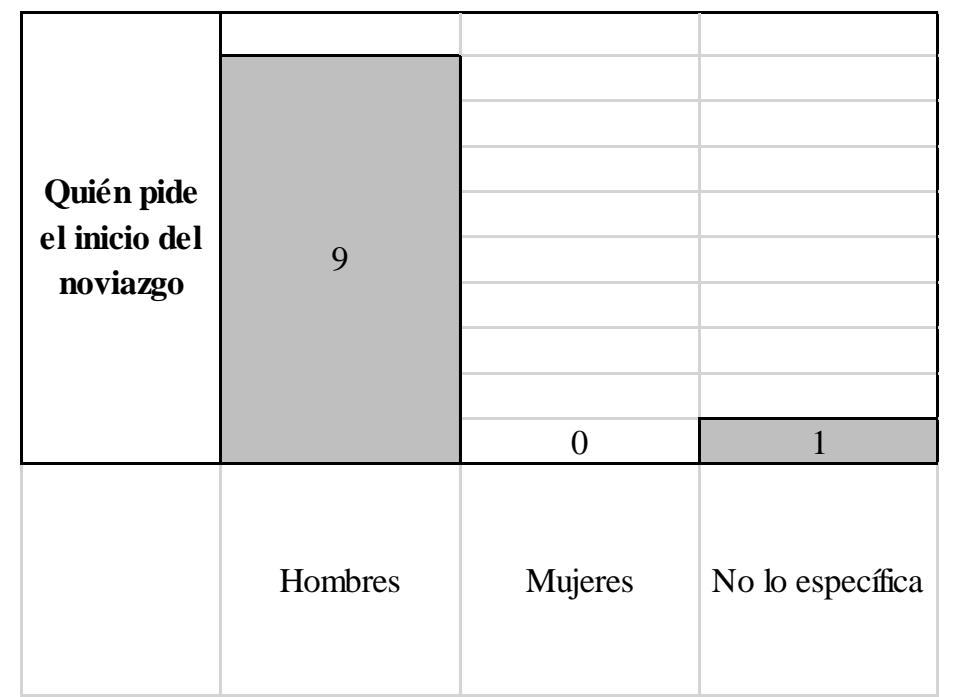

Figura 11. Diferencia de género en quién inicia la relación de noviazgo 


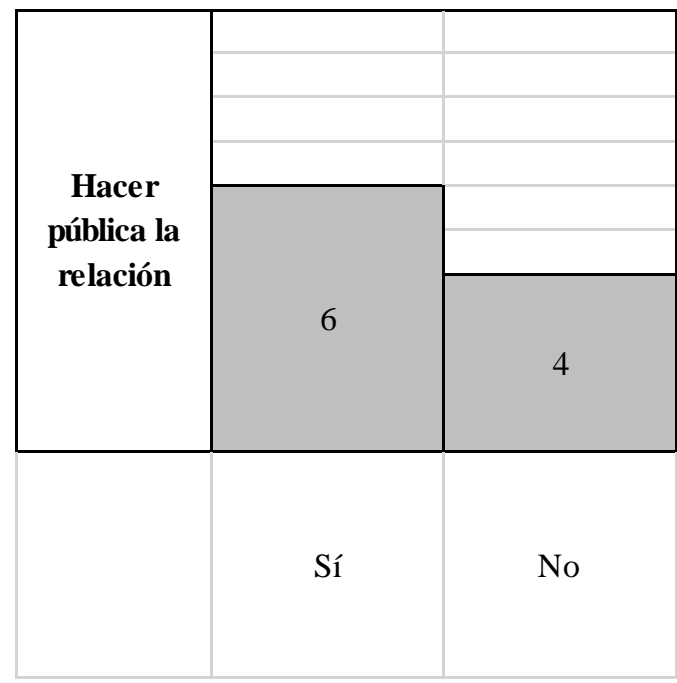

Figura 12. Hacer pública la relación

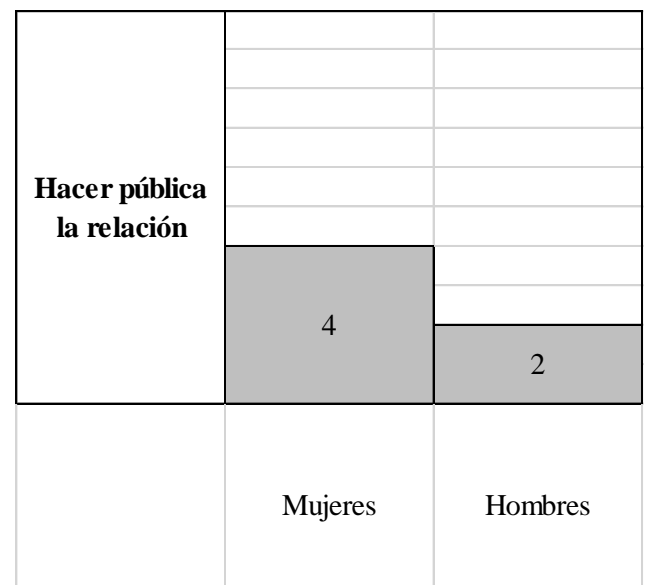

Figura 13. Diferencia de género al hacer pública la relación 


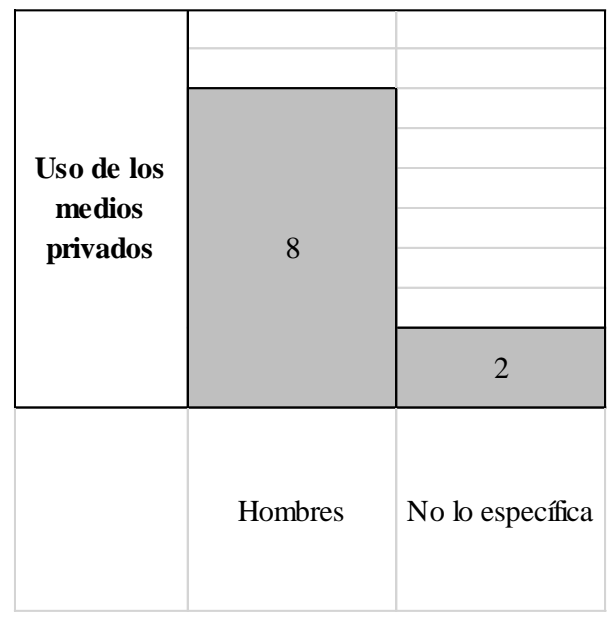

Figura 14. Diferencia de género en el uso de los medios privados

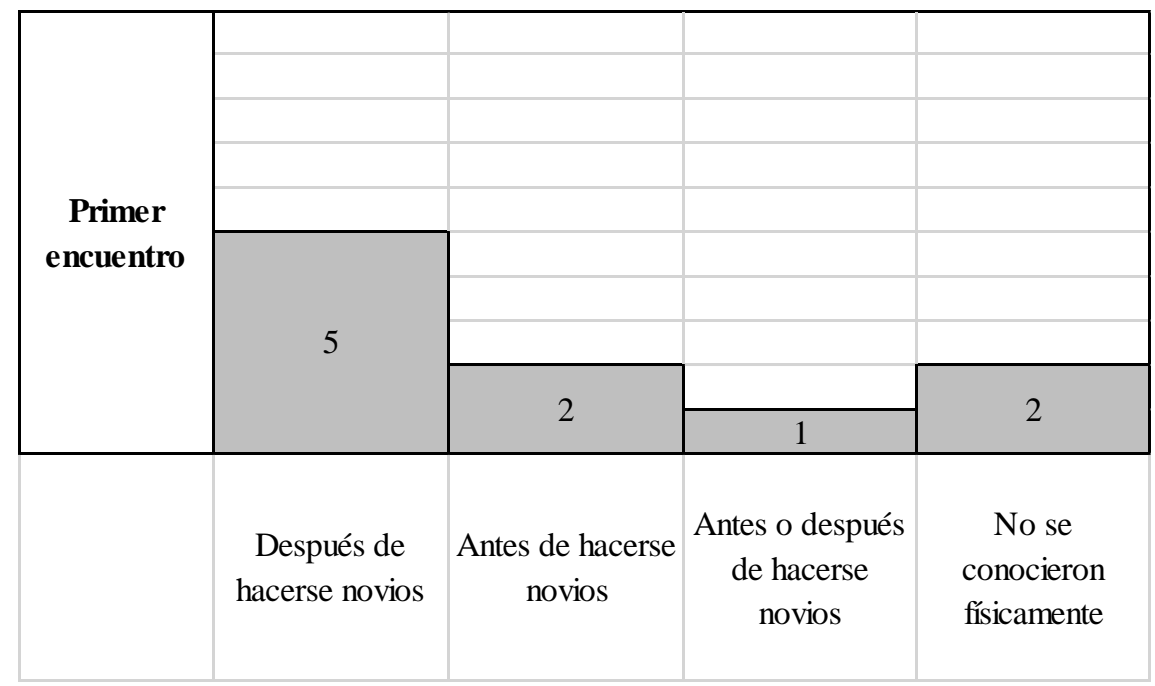

Figura 16. Primer encuentro 


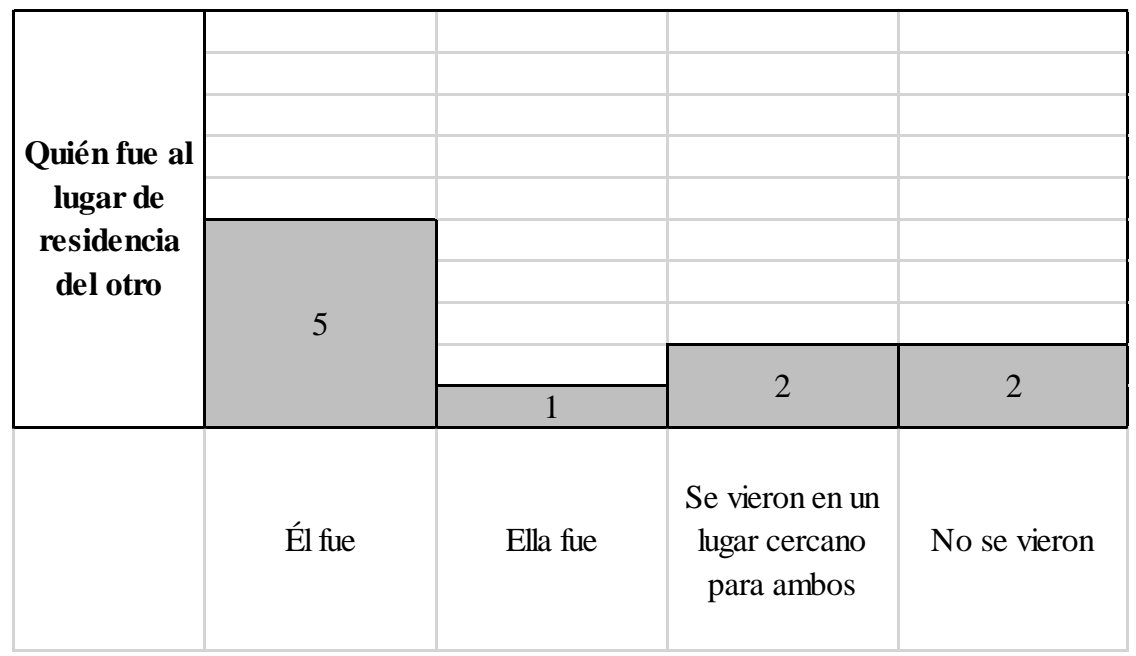

Figura 17. Diferencia de género de quién fue al lugar de residencia del otro

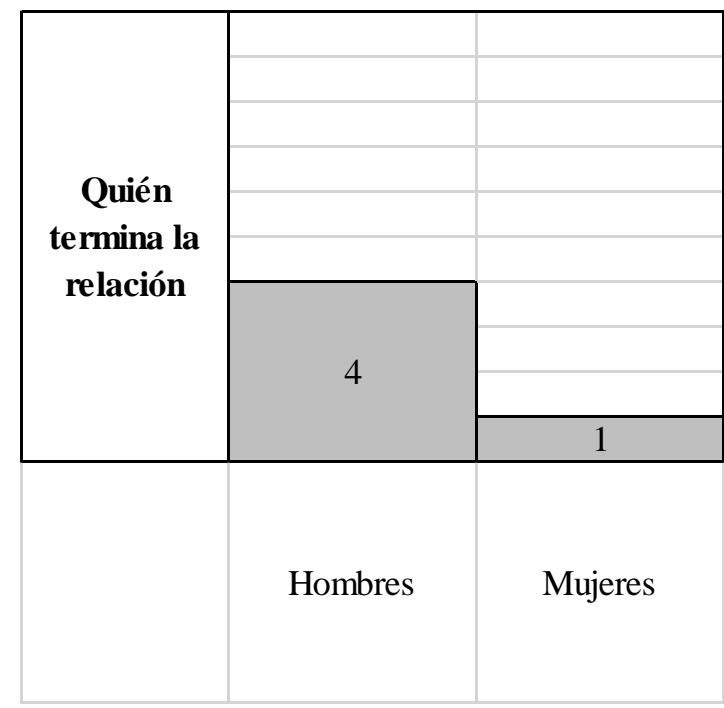

Figura 20. Diferencia de género respecto a quién termina la relación 


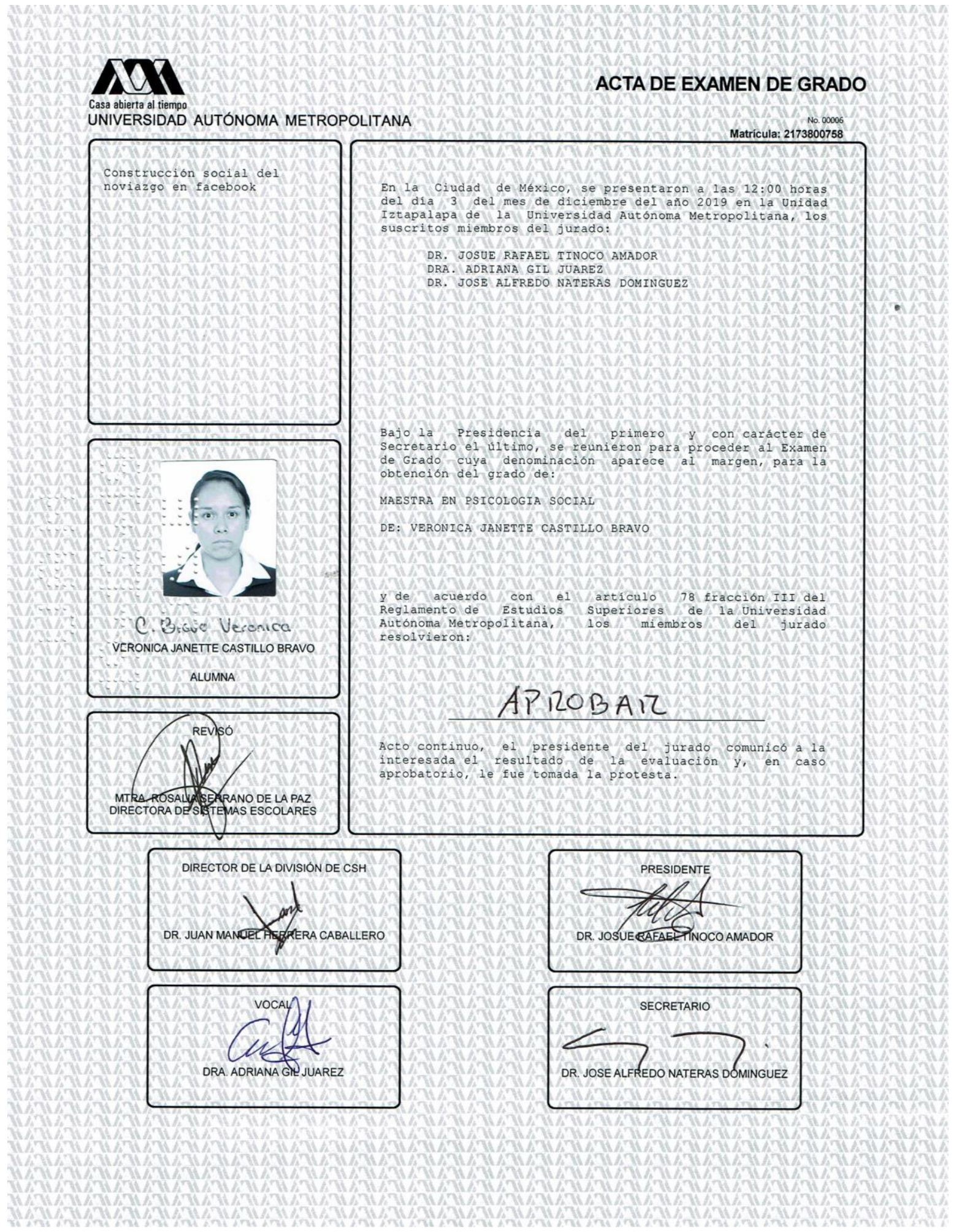

